\title{
Bioanalítica de Alicyclobacillus acidoterrestris - Detecção em frutas cítricas, isolamento microbiológico e classificação filogenética por técnicas biomoleculares e eletroforese em microchips
}

\author{
Maribel Elizabeth Funes Huacca \\ Tese de doutorado \\ apresentada ao Instituto \\ de Química de São \\ Carlos, Universidade de \\ São Paulo, como \\ requisito para a obtenção \\ do titulo de Doutor em \\ Ciências, área de \\ concentração Química \\ Analítica.
}

Orientador: Prof. Dr. Emanuel Carrilho.

São Carlos - São Paulo 


\title{
DEDICATORIA
}

\author{
Aos meus queridos pais, \\ Margarita e Filberto e \\ irmãs Milagros e Cristabel, \\ com quem eu gostaria de \\ compartilhar mais esta \\ vitória.
}




\section{AGRADECIMENTOS}

Ao Professor Dr. Emanuel Carrilho, pela sua valiosa orientação, apoio e confiança na realização deste trabalho. Agradeço acima de tudo o carinho e a amizade que me foram dispensados em todos esses anos em que tive oportunidade de ser sua orientada.

À Empresa Brasileira de Pesquisa Agropecuária (CPPSE-EMBRAPA), pela oportunidade oferecida para a realização do estagio e desenvolvimento de parte da tese.

À empresa Cargill Agrícola S.A., pelo treinamento e doação de amostras para as análises microbiológicas, especialmente a Wilson, Temístocles e Manuela.

À empresa Agilent Technologies, pela doação do equipamento Bioanalyzer 2100, em especial ao Dr. Odilo Müller pelas sugestões na utilização do equipamento.

À Dra. Luciana Correia de Almeida Regitano, pelas suas sugestões e coorientação no desenvolvimento das análises moleculares deste trabalho.

À Dra. Márcia C. de Sena Oliveira e Dra. Luciana Gatto Brito, pelo alegre convívio, por sua amizade e disponibilidade, sempre que solicitada.

Ao Dr. Carlos Dias Maciel, pela orientação no desenvolvimento das análises filogenéticas utilizando ferramentas de bioinformática.

À Dra. Regiane F. Travensolo, Bel. Juliana V. Alberice e MSc. Sheila B. Guterres, pela amizade e valiosa ajuda na elaboração deste trabalho.

A todos meus colegas do grupo de Cromatografia do Instituto de Química de São Carlos, pelo alegre convívio e amizade.

Aos meus queridos amigos Rosamel, Patricia, Miryam, Katlin, Giancarlo, Katia e Joel, pela valiosa amizade e alegre convívio desde que chegamos ao Brasil.

À Fundação de Amparo à Pesquisa do Estado de São Paulo (FAPESP), pelo suporte financeiro que possibilitaram a realização desse trabalho.

À Coordenação de Aperfeiçoamento de Pessoal de Nível Superior (CAPES), pela bolsa de estudo concedida no doutorado. 


\section{SUMÁRIO}

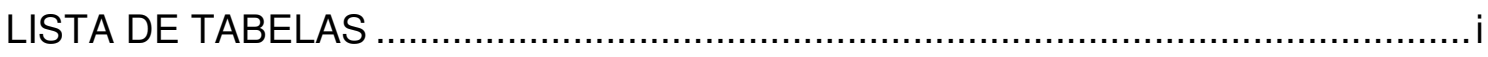

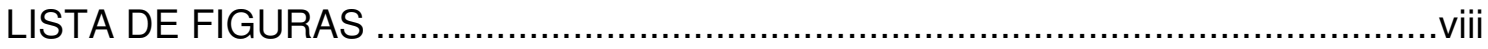

LISTA DE ABREVIATURAS E SIGLAS ………...........................................

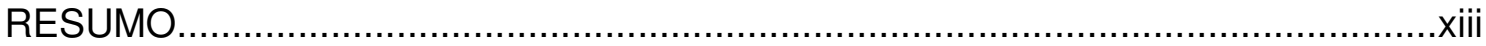

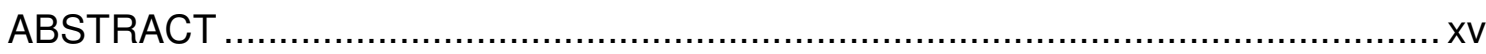

CAPÍTULO 1. INTRODUCÃO A TÉCNICAS MICROBIOLÓGICAS MOLECULARES ANALÍTICAS E FILOGENÉTICAS PARA A

DETECÇÃO E CLASSIFICAÇÃO DE Alicyclobacillus acidoterrestris.....................1

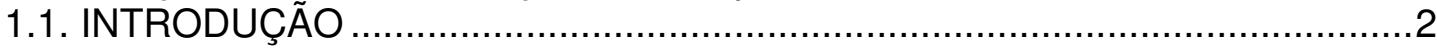

1.1.1. Ocorrência de Alicyclobacillus spp. em sucos de frutas............................

1.1.2. Métodos de detecção de Alicyclobacillus spp. .......................................

1.1.3. Inibição de Alicyclobacillus spp.......................................................

1.1.4. Técnicas moleculares para a detecção de microorganismos.....................

1.1.5. Métodos eletroforéticos para diagnóstico molecular ...............................12

1.1.6. Filogenia molecular para classificação bacteriana ................................14

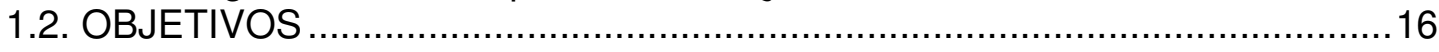

CAPÍTULO 2: DETECÇÃO DE Alicyclobacillus acidoterrestris EM SUCOS DE LARANJA POR RT-PCR E NESTED RT-PCR UTILIZANDO MÉTODOS ELETROFORÉTICOS DE ANÁLISE ….....................18

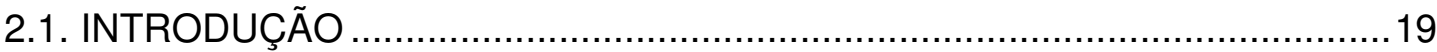

2.1.1. Métodos Quantitativos em RT-PCR …….......................................20

2.1.2. Diagnóstico e precisão analítica em PCR ……..................................22

2.1.3. Sensibilidade na detecção por nested PCR .......................................23

2.1.4. Atividade antibacteriana sobre Alicyclobacillus acidoterrestris ..............25

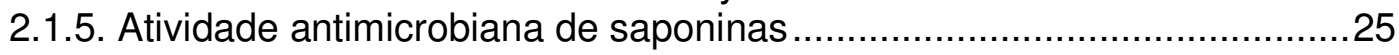

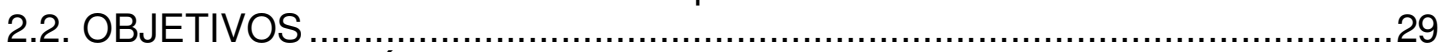

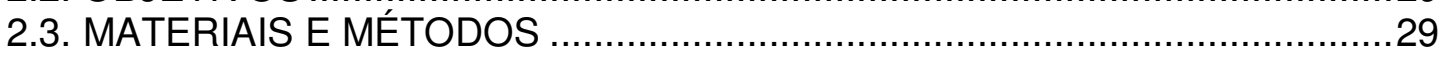

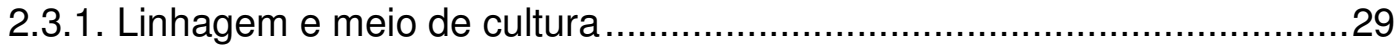

2.3.2. Sensibilidade nas reações de RT-PCR ..................................................30

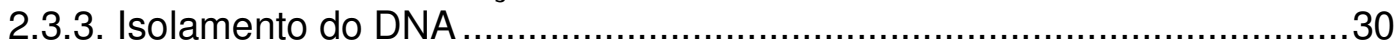

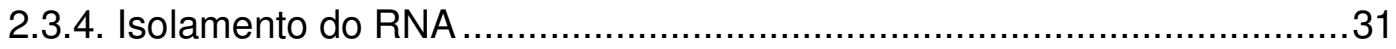

2.3.5. Transcrição reversa da RT-PCR ...................................................... 31

2.3.6. Desenho de primers para testes de nested RT-PCR em $A$. acidoterrestris ................................................................................

2.3.7. Otimização dos primers nested em reações nested PCR ........................33

2.3.8. Limite de detecção nas reações RT-PCR e nested RT-PCR ....................34

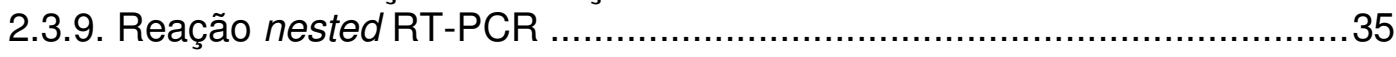

2.3.10. Detecção da viabilidade de $A$. acidoterrestris por RT-PCR ....................35

2.3.11. Monitoração da viabilidade de $A$. acidoterrestris por reações

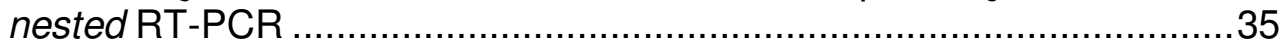

2.3.12. Eletroforese capilar em gel com deteç̧ão UV ....................................36

2.3.13. Detecção dos produtos amplificados por eletroforese em microchips.....

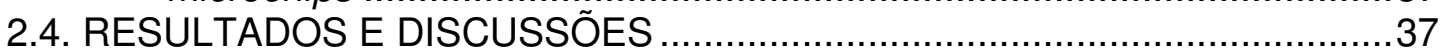


2.4.1. Comparação de métodos eletroforéticos para a detecção das A. Acidoterrestris.

2.4.2. Quantificação de $A$. acidoterrestris por RT-PCR em microchips

2.4.3. Comparação entre PCR e RT-PCR

2.4.4. Viabilidade e Inibição de $A$. acidoterrestris em sucos de laranja por RT-PCR. .44

2.4.5. Desenho dos primers nested para reações nested RT-PCR

2.4.6. Avaliação do limite de detecção em reações nested RT-PCR

2.4.7. Monitoração da viabilidade de A. acidoterrestris sob tratamento térmico e inibição com saponinas utilizando nested RT-PCR.

2.5. CONCLUSÕES

CAPÍTULO 3: ISOLAMENTO E CLASSIFICAÇÃO DE

ALICYCLOBACILLUS spp. EM DIFERENTES SUCOS DE FRUTOS

ÁCIDOS POR RAPD-PCR E ELETROFORESE CAPILAR EM

MICROCHIPS.

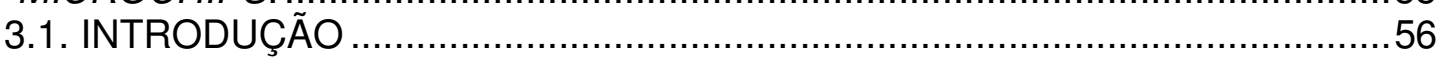

3.1.1. Taxonomia do gênero Alicyclobacillus ...............................................58

3.1.2. Detecção e identificação de $A$. acidoterrestris .....................................62

3.1.3. Polimorfismo de DNA por amplificação aleatória (RAPD-PCR) ...............63

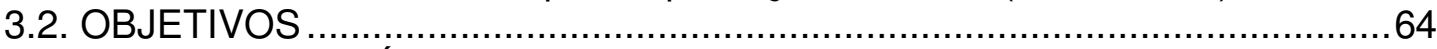

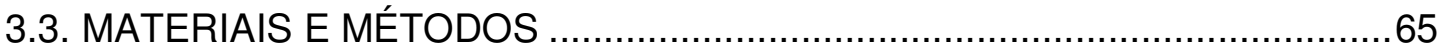

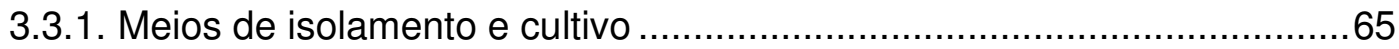

3.3.2. Isolamento e cultivo de Alicyclobacillus ..........................................66

3.3.3. Linhagens controle .................................................................... 68

3.3.4. Detecção e enumeração de esporos de Alicyclobacillus spp. em amostras de suco concentrado.

3.3.5. Detecção e enumeração de esporos de Alicyclobacillus em amostras de sucos diluídos ....

3.3.6. Detecção e enumeração de esporos de Alicyclobacillus em amostras de superfícies de frutas ácidas

3.3.7. Purificação e preservação das linhagens ..........................................70

3.3.8. Classificação filogenética por técnicas de RAPD-PCR ..........................71

3.4. RESULTADOS E DISCUSSÕES ...................................................... 74

3.4.1. Contagem em diferentes meios de cultivo por diferentes

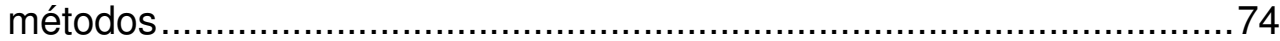

3.4.2. Caracterização morfológica e coloração Gram ....................................77

3.4.3. Extração e quantificação de DNA de cepas isoladas ............................79

3.4.4 Métodos eletroforéticos para análise de RAPD-PCR ...........................79

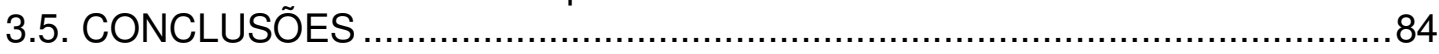

CAPÍTULO 4: ANÁLISE FILOGENÉTICA DE ALICYCLOBACILLUS spp.

DE AMOSTRAS DE SUCOS DE FRUTOS ÁCIDOS UTILIZANDO

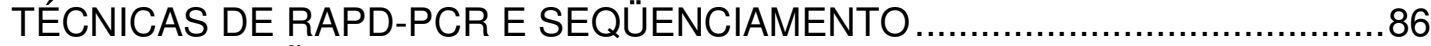

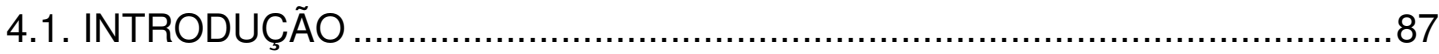

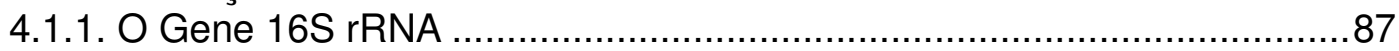

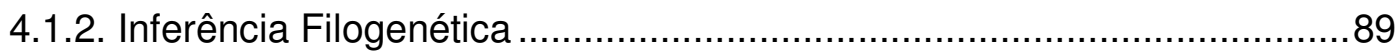

4.1.3. Análise de Similaridade Genética .............................................91 
4.1.4. Alinhamento de Seqüências ...................................................... 93

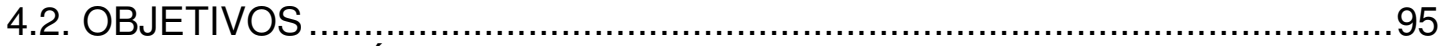

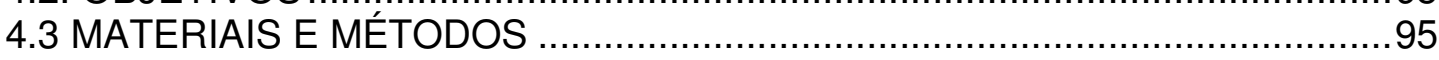

4.3.1. Análise de polimorfismos de RAPD das cepas isoladas ........................95

4.3.2. Construção da árvore de consenso para o polimorfismo de

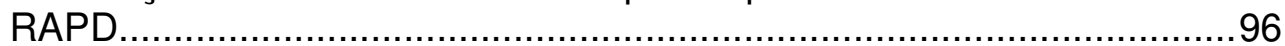

4.3.3. Amostragem de cepas de sucos de frutos ácidos ...............................96

4.3.4. Reações de seqüenciamento ........................................................97

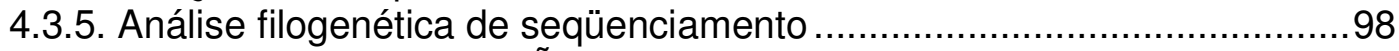

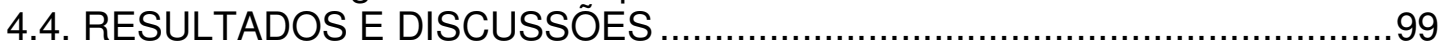

4.4.1 Análises filogenéticas com RAPD-PCR ......................................... 99

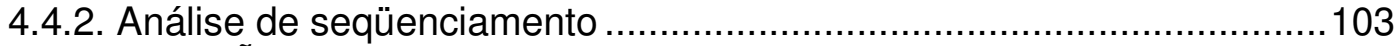

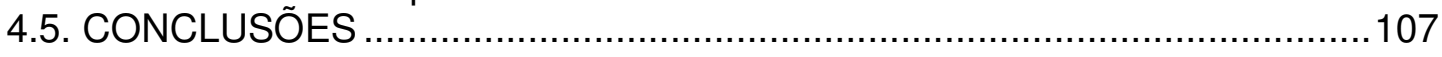

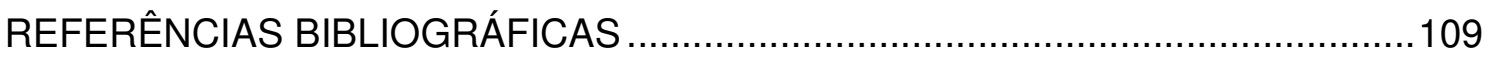




\section{LISTA DE TABELAS}

Tabela 2.1: Seqüência dos primers específicos dos Alicyclobacillus acidoterrestris (YAMASAKY, 1996)

Tabela 2.2: Seqüência de primers nested desenhados para detecção de Alicyclobacillus acidoterrestris em reações nested RT-PCR.

Tabela 2.3: Dados quantitativos de produtos de RT-PCR das A. acidoterrestris em sucos de laranja inoculados com e sem inibidor natural do extrato metanólico dos frutos da S. saponaria.

Tabela 2.4: Dados quantitativos de RT-PCR e nested RT-PCR de produtos de A. acidoterrestris, em sucos de laranja inoculado com fração purificada de inibidor (Sapindus saponaria) e tratamentos à $99^{\circ} \mathrm{C}$.

Tabela 3.1: Amostras de sucos de frutas concentrados, diluídos e de superfície de frutas ácidas.

Tabela 3.2: Linhagens controle do gênero Alicyclobacillus spp. ......................... 68

Tabela 3.3: Seqüência de primers utilizados na reação de RAPD-PCR. ............ 73

Tabela 3.4: Efeito dos diferentes métodos e meios de enriquecimento e contagem, na detecção de Alicyclobacillus spp. em amostras de sucos concentrados e superfície de frutas ácidas.

Tabela 3.5: Contagem de bactérias em sucos concentrados, diluídos e de superfícies de diferentes frutas ácidas.

Tabela 4.1: Amostras controle e cepas isoladas de diferentes sucos de frutas, escolhidas para o seqüenciamento do gene 16S rRNA pertencente ao gênero Alicyclobacillus spp.

Tabela 4.2: Informação das seqüências alinhadas a partir das cepas isoladas em sucos e frutas ácidas. 105 


\section{LISTA DE FIGURAS}

Figura 1.1: Eletroforese no Lab-on-a-Chip Agilent 2100 Bioanalyzer... 13

Figura 2.1: Diagrama para reação de nested PCR na amplificação específica de um alvo de DNA para reação nested PCR...............24

Figura 2.2: Saponinas isoladas de Sapindus saponaria (MURGU, 2006). .......26

Figura 2.3: Determinação do número mínimo de UFC/mL para detecção positiva de $A$. acidoterrestris por PCR. Identificação das canaletas: marcador de tamanho de DNA phiX174/Hae III (M), $10^{3} \mathrm{UFC} / \mathrm{mL}(1), 10^{2} \mathrm{UFC} / \mathrm{mL}$ (2), $10 \mathrm{UFC} / \mathrm{mL}$ (3), 1 $\mathrm{UFC} / \mathrm{mL}(4), 10^{-1} \mathrm{UFC} / \mathrm{mL}$ (5), $10^{-2} \mathrm{UFC} / \mathrm{mL}(6), 10^{-3} \mathrm{UFC} / \mathrm{mL}$ (7), $10^{-4} \mathrm{UFC} / \mathrm{mL}(8), 10^{-5} \mathrm{UFC} / \mathrm{mL}$ e controle negativo (9)

Figura 2.4: Eletroferograma de eletroforese capilar em gel com deteç̧ão espectrofotométrica em $260 \mathrm{~nm}$ para amostras de PCR em diferentes graus de inoculação em sucos de laranja com $A$. acidoterrestris (ATB).

Figura 2.5: Eletroferograma com detector LIF para amostras de PCR a diferente grau de inoculação em sucos de laranja das $A$. acidoterrestris (ATB) em plataforma microfluidica.

Figura 2.6: Variação de concentração de amplicons de RT-PCR de produtos do gene de $A$. acidoterrestris. Concentração de amplicons de RT-PCR suspendidos em médio de $2 \times 10^{5}-2$ $\mathrm{UFC} / \mathrm{mL}$ depois de 0 e $12 \mathrm{~h}$ de incubação.

Figura 2.7: Comparação entre produtos de RT-PCR detectados no meio YGS e sucos de laranja inoculado com $A$. acidoterrestris, nas concentrações de $2 \times 10^{4}$ até 2 UFC mL ${ }^{-1}$

Figura 2.8: Comparação entre quantidade amplicons de PCR e RT-PCR das $A$. acidoterrestris em diluições de $2 \times 10^{5}-2 \mathrm{UFC} / \mathrm{mL}$, para $0 \mathrm{~h}(\mathrm{~A})$ e $12 \mathrm{~h}$ de incubação. Testes realizados no Bionalyzer 2100 (Agilent Technologies).

Figura 2.9: Comparação de amplicons de RT-PCR (294 bp) em amostras de culturas puras e sucos de laranja inoculados com A. acidoterrestris.

Figura 2.10: Eletroferograma de $1 \times 10^{4} \mathrm{UFC} / \mathrm{mL}$ em sucos de laranja e depois do tratamento com inibidor por dois e quatro dias.

Figura 2.11: Seqüência do amplicon de 294 bp de A. acidoterrestris mostrando o pareamento dos primers NAtb-F e NAtb-R.

Figura 2.12: Eletroforese em microchips de produtos nested RT-PCR. Limite de detecção de nested RT-PCR de $A$. acidoterrestris inoculados com $6 \times 10^{4}$ até 0,1 UFC $\mathrm{ml}^{-1}$, usando 0 Bioanalyzer 2100 (Agilent Technologies).

Figura 2.13: Comparação entre produtos de RT-PCR e nested RT-PCR detectados a partir de $A$. acidoterrestris inoculados no meio

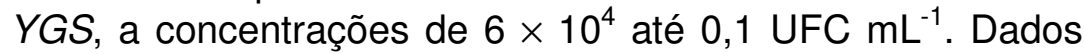
quantitativos foram obtidos usando o Bioanalyzer 2100 (Agilent Technologies). 
Figura 2.14: Eletroforese em microchips de RT-PCR (294 bp) e nested RT-PCR (191 bp) de $A$. acidoterrestris inoculados com $4 \times$ $10^{4}$ UFC $\mathrm{mL}^{-1}$ em suco de laranja. Comparação da viabilidade com tratamento de temperatura: (1) RT-PCR, suco de laranja, (2) RT-PCR, suco de laranja tratado a 99 ${ }^{\circ} \mathrm{C} / 1 \mathrm{~h}$, (3) nested RT-PCR, suco de laranja tratado a 99

${ }^{\circ} \mathrm{C} / 1 \mathrm{~h}$. ..........................................................................

Figura 2.15: Eletroforese em microchips de RT-PCR (294-bp) de $A$.
acidoterrestris inoculados com $4 \times 10^{4}$ UFC mL $\mathrm{mL}^{-1}$ em suco de laranja. Monitoração da viabilidade: (1) suco de laranja, (2) suco de laranja tratado a $99^{\circ} \mathrm{C} / 1 \mathrm{~h}$, (3) suco de laranja com S. saponaria $\left(200 \mathrm{mg} \mathrm{L}^{-1}\right)$, tratado a $45^{\circ} \mathrm{C} / 2 \mathrm{~d}$ (4) suco de laranja com $S$. saponaria $\left(200 \mathrm{mg} \mathrm{L}^{-1}\right)$, tratado a $99^{\circ} \mathrm{C} / 1 \mathrm{~h}$.

Figura 3.1: Diagrama da Reação de Polimorfismos de DNA por Amplificação Aleatória (RAPD).

Características macroscópicas de colônias de Alicyclobacillus spp. isolada de sucos de laranja concentrado. Contagem em diluição $1: 10^{1}(\mathrm{~A})$ e $1: 10^{3}(\mathrm{~B})$.

Figura 3.3: Características morfológicas visualizadas através de coloração Gram. (A) controle C2 correspondente a $A$. acidoterrestris e (B) controle $\mathrm{C} 1$ correspondente a $A$. acidoterrestris da empresa Cargill S.A.

Figura 3.4: Características morfológicas, visualizadas através de coloração Gram. (C) cepa isolada de suco concentrado de limão, (D) cepa isolada de suco diluído de abacaxi.

Figura 3.5: Análise eletroforética (gel virtual) dos produtos de amplificação do RAPD-PCR das vinte e quatro cepas isoladas, analisadas com o primer P4: L (marcador de tamanho de DNA) e as amostras estão codificadas segundo a Tabela 3.1.

Figura 3.6: Eletroferograma de produtos de RAPD com o primer P5. Comparação entre os controles $A$. acidoterrestris $(\mathrm{C} 1), A$. acidocaldarius (C3), A. cicloheptánicus C4 e uma cepa isolada de suco de laranja in natura, analisados no Bioanalyzer 2100 Lab-on-a-Chip.

Figura 3.7: Eletroferograma de produtos de RAPD com o primer E2. Comparação entre $A$. acidoterrestris (C2), suco concentrado de laranja (2), suco diluído de abacaxi (15) e cepa isolada de superfície de limões, analisados no Bioanalyzer 2100 Lab-ona-Chip.

Figura 3.8: Eletroferograma de produtos de RAPD com o primer E15. Comparação entre cepas de suco concentrado de laranja (2), superfície de laranjas do pomar do solo e do meio (T1 e T4) e superfície de laranjas do comercio, analisados no Bioanalyzer 2100 Lab-on-a-Chip. 
Figura 3.9: Eletroferograma de produtos de RAPD com o primer E16. Comparação entre o controle extraído do Japão (C5) e as cepas isoladas de suco concentrado de laranja (2), suco diluído de laranja (6), superfície de maracujás (7) e suco concentrado de limão (lim), analisados no Bioanalyzer 2100 Lab-on-a-Chip.

Figura 4.1: Diagrama dos alinhamentos de seqüências local e global.............. 94

Figura 4.2: Árvore filogenética com coeficientes de similaridade, obtida com o primer E2. A identificação completa das cepas encontra-se na Tabela 3.1 do Capítulo 3...

Figura 4.3: Árvore filogenética com coeficientes de similaridade, obtida com o primer E15. A identificação completa das cepas encontra-se na Tabela 4.1.

Figura 4.4: Árvore de consenso obtida com base no suporte de bootstrap com os dados originais dos cinco primers utilizados.

Figura 4.5: Árvore filogenética, utilizando os métodos neighbor joining e bootstrap 1000×, mostrando a posição filogenética das cepas obtidas de sucos e frutos ácidos, baseados nas seqüências do $16 \mathrm{~S}$ rRNA. 


\section{LISTA DE ABREVIATURAS E SIGLAS}

$\begin{array}{ll}\text { ATCC } & \text { American type culture collection. } \\ \text { BAM } & \text { Bacillus acidocaldarius medium. } \\ \text { BAT } & \text { Bacillus acidoterrestris médium. } \\ \text { bP } & \text { Pares de base. } \\ \text { CCT } & \text { Coleção de culturas tropicais } \\ \text { CDNA } & \text { Ácido desoxiribonucléico complementar. } \\ \text { CE } & \text { Eletroforese capilar. } \\ \text { DAD } & \text { Detector com arranjo de diodos. } \\ \text { DEFT } & \text { Técnica epifluorescência com filtro direto. } \\ \text { DEPC } & \text { Dietil pirocarbonato. } \\ \text { DNA } & \text { Ácido desoxiribonucléico. } \\ \text { DNase I } & \text { Enzima desoxiribonuclease I. } \\ \text { EMBL } & \text { European molecular biology laboratory. } \\ \text { FT-IR } & \text { Espectroscopia de infravermelho por transformada de } \\ \text { Fourier. } & \\ \text { HaeIII } & \text { Kilodalton } \\ \text { aegypticus. } & \\ \text { HEC } & \text { Hidroxietilcelulose. } \\ \text { IDNS } & \text { Integrated database network system. } \\ \text { KDa } & \text { Detecção de fluorescência induzida a laser. } \\ \text { LIF } & \text { Concentração de inibição mínima parcimônia. } \\ \text { MIC } & \\ \text { MP } & \end{array}$


MS Espectrometria de massa.

MS Máxima semelhança.

$\mathrm{NCBI} \quad$ National center for biotechnology information.

nested PCR Reação em cadeia da polimerase por nested.

NlaIII Enzima de restrição da Neisseria lactamica.

OSA Agar orange serum.

PBS Tampão fosfato salino.

PCR Reação em cadeia da polimerase.

PDA Agar potato dextrose.

PVA Polivinilalcool.

RAPD Polimorfismo de DNA por amplificação aleatória.

RDP Ribosomal database project.

RFLP Polimorfismo no comprimento de fragmentos de restrição.

RFU Relative fluorescence unit.

RIDOM Ribosomal differentiation of medical microorganisms.

RNA Ácido ribonucléico.

RNase A Enzima ribonuclease tipo A.

rRNA Ácido ribonucléico ribossomal.

rt-PCR reação em cadeia da polimerase em tempo real.

RT-PCR Transcrição reversa da reação em cadeia da polimerase.

UFC Unidade formadora de colônias.

UPGMA Unweighted pair group method with arithmetic mean.

UV Ultravioleta.

YGS Agar yeast-starch glucose. 


\section{RESUMO}

Neste trabalho desenvolvemos métodos analíticos e moleculares para a detecção, isolamento e classificação filogenética de Alicyclobacillus spp. a partir de sucos de laranja e frutos ácidos, pelas técnicas: RT-PCR, nested RT-PCR, RAPD, seqüenciamento do 16S rRNA e análise por métodos eletroforéticos. A sensibilidade na detecção dos $A$. acidoterrestris foi melhorada por meio de reações de nested RT-PCR, utilizando primers internos (amplicon de $191 \mathrm{bp}$ ) que foram desenhados a partir do primeiro amplicom de 294 bp. O limite de detecção foi estudado com as reações RT-PCR e nested RT-PCR, sendo capazes de detectar concentrações de $0,1 \mathrm{UFC} \mathrm{mL}^{-1}$ para culturas puras e 2 UFC $\mathrm{mL}^{-1}$ em sucos de laranja artificialmente inoculados. A inibição de esporos de $A$. acidoterrestris também foi estudada para monitorar a diminuição da viabilidade com tratamento térmico e Sapindus saponaria (200 $\mathrm{mg} \mathrm{L}^{-1}$ ), utilizando RT-PCR e nested RT-PCR. Com o tratamento térmico de $99{ }^{\circ} \mathrm{C}$ por $1 \mathrm{~h}$ o grau de inibição dos esporos foi de $96,3 \%$. Enquanto que, com a fração purificada de $S$. saponaria $\left(200 \mathrm{mg} \mathrm{L}^{-1}\right)$ incubada à $45^{\circ} \mathrm{C}$ por 2 dias foi de $93,6 \%$, mas com incubação de $99{ }^{\circ} \mathrm{C}$ por $1 \mathrm{~h}$ foi de $98,7 \%$, na mesma concentração de saponina. Todas as análises de quantificação de produtos de RT-PCR e nested RT-PCR foram analisadas por meio de eletroforese em gel de agarose e eletroforese capilar em microchip no Bioanalyzer 2100 (Agilent), com os kits DNA 500 e DNA 1000 LabChip $^{\circledR}$, obtendo-se maior sensibilidade nos microchips. A classificação molecular de dezenove cepas, isoladas a 
partir de diferentes sucos e frutos ácidos, foram estudadas utilizando RAPD-PCR e eletroforese capilar em microchips. Utilizando cinco primers aleatórios nas reações de RAPD, foi possível estudar os polimorfismos analisados nos microchips. Segundo as análises eletroforéticas, as cepas de suco concentrado e diluído de laranja (1, 2, 6) suco concentrado de limão (lim) e suco de laranja in natura (T2, T3), apresentaram similaridades genéticas com a $A$. acidoterrestris. $\mathrm{O}$ estudo de análise filogenética baseada na comparação de seqüências de DNA da região variável do gene $16 S$ rRNA de Alicyclobacillus acidoterrestris, foi utilizado para identificar e agrupar onze cepas isoladas de superfícies e sucos de frutos ácidos. Na árvore filogenética gerada pelo método neighbor joining e bootstrap 1000×, as cepas analisadas mostraram similaridades de $99 \%$ entre todas elas, observando-se uma maior similaridade do controle $A$. acidoterretris (C2) com a cepa isolada de suco concentrado de limão (lim), e uma boa discriminação entre controles das espécies A. acidocaldarius, A. cicloheptanicus, A. sendaiensis e Sulfobacillus acidophilus. 


\section{ABSTRACT}

In this work, we developed analytical and molecular methods for detection, isolation and phylogenetic classification of Alicyclobacillus spp. from orange juice and acid fruits using RT-PCR, nested RT-PCR, RAPD and sequencing of $16 \mathrm{~S}$ rRNA techniques and electrophoretic methods of analysis. The sensitivity on the detection of $A$. acidoterrestris in orange juice was improved by nested RT-PCR, using internal primers (amplicon of $191 \mathrm{bp}$ ) that were designed after sequencing the first amplicon (294 bp). The detection limit was studied with RT-PCR and nested RT-PCR

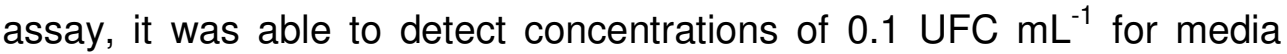
culture and 2 UFC mL $\mathrm{mL}^{-1}$ in inoculated orange juice. The inhibition in spores from $A$. acidoterrestris was also studied to monitoring the diminution of viability with heat treatment and Sapindus saponaria (200 $\mathrm{mg} \mathrm{mL}^{-1}$ ), using RT-PCR and nested RT-PCR assays. The inhibition by heat treatment at $99{ }^{\circ} \mathrm{C}$ for $1 \mathrm{~h}$ was $96.3 \%$. However, incubation with $S$. saponaria at $45^{\circ} \mathrm{C}$ for 2 days inhibited $93,6 \%$, however, with incubation of $99{ }^{\circ} \mathrm{C}$ for $1 \mathrm{~h}$ was $98,7 \%$, in the same concentration of saponin. The quantification of the RT-PCR and nested RT-PCR amplification product were accomplished by capillary electrophoresis in microchips using the Bioanalyzer 2100 in conjunction with the LabChip ${ }^{\mathrm{TM}}$ DNA 500 and DNA 1000. The molecular classification of nineteen strains isolated from different juice and acidic fruit, were studied using RAPD-PCR and capillary electrophoresis in microchips. Using five random primers in the RAPD assay, it was possible to study the polymorphisms analyzed in 
microchips. According to electrophoresis analyses, the strains from concentrated and diluted orange juices $(1,2,6)$, lemon concentrated juice (lim) and natural orange juice (T2, T3), showed genetic similarities with the $A$. acidoterrestris. The study of the phylogenetic analyses based on DNA comparison sequences of the variable region of $16 \mathrm{~S}$ rRNA gene from Alicyclobacillus acidoterrestris, was utilized for the identification and grouping of eleven strains isolated from surface and juice of acid fruits. In the phylogenetic tree produced by neighbor joining and bootstrap 1000x, the strains showed similarities of $99 \%$ among all strains, showing a high similarity of $A$. acidoterrestris with a strain isolated from lemon concentrate juice (lim), and a good discrimination between the species $A$. acidocaldarius, A. cycloheptanicus, A. sendaiensis and Sulfobacillus acidophilus.. 
CAPÍTULO 1. INTRODUCÃO A TÉCNICAS MICROBIOLÓGICAS MOLECULARES ANALÍTICAS E FILOGENÉTICAS PARA A DETECÇÃO E CLASSIFICAÇÃO DE Alicyclobacillus acidoterrestris. 


\subsection{INTRODUÇÃO}

A indústria de sucos de frutas movimenta grande parte do mercado brasileiro, sendo, o suco de laranja, seu produto de maior destaque. Tais indústrias representam um mercado anual de aproximadamente US $\$ 1,5$ bilhões e estão concentradas principalmente no estado de São Paulo.

No início dos anos 90, o suco de laranja brasileiro correu sérios riscos de ser eliminado da pauta de importações da comunidade européia, devido ao surgimento de uma bactéria, que adultera o sabor e o odor do produto. Este fato estava intimamente relacionado aos verões europeus excepcionalmente quentes. Estudos realizados por diversos pesquisadores reportaram uma bactéria termoacidófila esporofórmica não patogênica do gênero Alicyclobacillus spp. como causadora da deterioração dos sucos. A bactéria pode proliferar-se em sucos ácidos quando estes são manuseados ou estocados de forma imprópria durante e após a pasteurização. A contaminação também pode ser ocasionada por microorganismos presentes no solo ou ainda pela água de lavagem.

A ocorrência desses microrganismos em sucos de laranja ganhou importância internacional após os episódios de deterioração nos sucos reconstituídos, pasteurizados e embalados no mercado Europeu nos anos de 1994 e 1995 (EGUCHI, 1999). Esses eventos causaram uma grande preocupação nas indústrias brasileiras de cítricos, fazendo crescer o interesse, na detecção e controle de qualidade em sucos de laranja, com a utilização de novas técnicas moleculares para detecção desses microorganismos, já que as técnicas convencionais mostraram-se ineficientes nesse caso.

Por meio de técnicas microbiológicas, a identificação de Alicyclobacillus spp. é realizada pela observação das características morfológicas das células e das 
colônias, crescimento sob diferentes temperaturas e pH, utilização de fontes de carbono e testes bioquímicos convencionais, como catalase, oxidase e produção de acetoína, entre outros. Contudo, a diferenciação entre as espécies em vários casos é insatisfatória, necessitando recorrer-se a técnicas quimiotaxonômica, taxonomia molecular e filogenética.

Entretanto, técnicas moleculares, particularmente interessantes para a indústria de alimentos, estão sendo desenvolvidas para análises mais rápidas e específicas que as técnicas de cultivo e identificação microbiológica convencional, e também para a detecção de novos microorganismos.

Neste capítulo, será apresentada uma breve introdução de todas as técnicas utilizadas no trabalho tais como: microbiológicas, analíticas, moleculares e filogenéticas para a detecção e classificação das bactérias Alicyclobacillus acidoterrestris, em sucos de laranjas e em diferentes cepas isoladas a partir de diferentes sucos de frutos ácidos, respectivamente. Com a utilização de métodos moleculares e novas metodologias de miniaturização poderemos obter maior sensibilidade na quantificação e classificação das bactérias $A$. acidoterrestris, que causam graves problemas na indústria de cítricos no Brasil.

\subsubsection{Ocorrência de Alicyclobacillus spp. em sucos de frutas}

A contaminação dos sucos ocorre, provavelmente, através da fruta contaminada pelo solo na colheita. A entrada de Alicyclobacillus spp. no processamento dos sucos torna-se possível quando um sistema de lavagem e limpeza da fruta é ineficaz ou quando o tratamento de pasteurização não é eficiente para destruir seus esporos (BROWN, 1996). 
As diversas vias de contaminação por Alicyclobacillus spp. podem ser contaminados com microflora primaria ou secundaria. A microflora primaria geralmente se adere na superfície dos frutos devido às forças interativas entre a planta e a estrutura da parede celular dos microorganismos. A microflora secundária é representada por vetores externos tais como solo, poeira, vento, chuva, as quais podem ser depositadas na superfície dos frutos (DOORES, 1983; KOMITOPOULOU, 1999). Água utilizada para produzir bebidas é também identificada como uma fonte de contaminação segundo (McINTYRE, 1995; WALLS, 1998).

As características de deterioração causada por Alicyclobacillus são: a presença de odor e sabor desagradáveis (descrito como anti-séptico, desinfetante), embora muitas vezes o odor produzido pela deterioração seja pouco perceptível. Não há formação de gases; pouca ou nenhuma alteração de $\mathrm{pH}$, podendo, apresentar um aumento da turbidez do produto e a formação de um sedimento branco no fundo da embalagem, ou mesmo uma aparência normal. O sabor e odor desagradáveis são atribuídos à formação dos compostos 2-6 di-bromofenol (halofenol) e de 2-metoxifenol (guaiacol) respectivamente (BORLINGHAUS, 1997; BROWN, 1996).

Trabalhos sobre o isolamento de Alicyclobacillus spp. foram realizados por YAMASAKI (1996) e WEBSTER (1996). O primeiro autor e colaboradores isolaram no Japão linhagens de $A$. acidoterrestris a partir de amostras de bebidas ácidas deterioradas, e sugeriu que alimentos ácidos devem ter sua qualidade avaliada quanto à presença de $A$. acidoterrestris, já os outros autores também isolaram $A$. acidoterrestris, neste caso a partir de amostras não deterioradas de sucos de frutas e de tomate enlatado. 
WISSE e colaboradores (1998) detectaram e enumeraram bacilos esporulados acidotermofílicos em amostras provenientes de várias etapas da linha de processamento industrial de suco de laranja concentrado, na Florida (EUA).

A primeira ocorrência da deterioração de sucos embalados assepticamente de que se tem relatado, deu-se na Alemanha, no verão de 1982 (CERNY, 1984). Desde então diferentes espécies de Alicyclobacillus foram isoladas de diversas matrizes, como sucos de frutas ácidas, bebidas ácidas isotônicas deterioradas, solos vulcânicos, regiões termais, etc. A presença de Alicyclobacillus nesses habitats foram reportados por muitos pesquisadores de diferentes partes do mundo, incluindo Austrália, Brasil, Itália, Japão, Rússia e os Estados Unidos (GOTO, 2002).

A contaminação por Alicyclobacillus spp. em sucos de frutas pasteurizados apresenta um desafio considerável para a indústria de alimentos. Estudos sobre a temperatura de estocagem de sucos de frutas pasteurizados indicaram que esses microorganismos não crescem a temperaturas menores de $20{ }^{\circ} \mathrm{C}$ (JENSEN, 2003). No entanto, sucos de frutos pasteurizados são principalmente distribuídos sob temperatura ambiente e o resfriamento desses produtos levaria a um maior fator de custos. Outra alternativa para inibir o crescimento dos esporos, seria aumentar a temperatura de pasteurização até aproximadamente $100^{\circ} \mathrm{C}$, mas isso não seria factível devido a que a elevada temperatura produziria mudanças organolépticas não aceitas no produto final (CHANG, 2004).

Nas indústrias brasileiras de cítricos, cresce o interesse para o controle e detecção mais rápida e confiável de $A$. acidoterrestris, devido a que um pequeno número de esporos viáveis destas bactérias tem o potencial para contaminar grandes volumes de sucos concentrados, resultando em graves perdas financeiras para o setor. Os consumidores e importadores de sucos concentrados de laranja 
têm se tornado mais exigentes na qualidade do produto e tem uma expectativa de incrementar a consistência em todos os parâmetros de qualidade.

Porém, esses eventos fazem crescer o interesse, na detecção e controle de qualidade em sucos de laranja, com a utilização de novas técnicas moleculares para detecção desses microorganismos, já que as técnicas convencionais mostraram-se ineficientes nesse caso.

\subsubsection{Métodos de detecção de Alicyclobacillus spp.}

\subsubsection{Métodos microbiológicos}

Resumindo os numerosos estudos com respeito aos Alicyclobacillus spp., existem duas categorias maiores de isolamento: plaqueamento em meio de cultura e filtração. Freqüentemente, as temperaturas de incubação oscilam de 37 a $55^{\circ} \mathrm{C}$, e o meio de cultura são acidificados por ácido málico, $\mathrm{HCl}$ ou $\mathrm{H}_{2} \mathrm{SO}_{4}$ a pH 3,5-4,0.

Vários meios de cultura foram usados na tentativa de isolar Alicyclobacillus spp. Embora essas bactérias exibam extraordinária sobrevivência sob condições extremas, elas não são capazes de crescer em todos os meios. Os meios comumente utilizados para o isolamento são: meio Bacillus acidocaldarius (BAM), agar orange serum (OSA), agar potato dextrose (PDA), agar Yeast-Starch-Glucose (YSG), agar K (SPLITTSTOESSER, 1994; SILVA, 1999, 2001; PETTIPHER, 2000).

A técnica de filtração em membrana teve bons resultados na detecção de Alicyclobacillus spp. em sucos de frutas (VIEIRA, 2000). Os A. hesperidum foram isolados da suspensão de solos por Albuquerque (2000) com a utilização de filtros de membrana tipo Gelman GN-6 (tamanho do poro 0,45 $\mu \mathrm{m}$ e diâmetro de 47 mm), também foram reportados o isolamento de $A$. herbarius (GOTO. b, 2002). A filtração 
por membrana teve maior sensibilidade na detecção comparada ao plaqueamento de superfície (spread plate) convencional.

Algumas indústrias de suco de frutas estão incorporando o método de filtração com membrana, como procedimento de rotina no controle de qualidade. Entretanto, os diferentes materiais e procedimentos envolvidos na produção variam amplamente entre os diferentes fabricantes de filtros de membrana. Porém seria importante que filtros de membrana geralmente utilizados ou disponíveis sejam avaliados pela capacidade de reter esporos de Alicyclobacillus spp. (CHANG, 2004).

\subsubsection{Métodos microscópicos}

Pettipher e Osmundson (2000) reportaram o uso da técnica epifluorescência com filtro direto (DEFT) para isolar Alicyclobacillus spp. O DEFT é uma modificação da filtração por membrana, utilizando corantes fluorescentes e microscopia (JAY, 2000). Tipicamente, sucos de frutas são filtrados através de membranas de policarbonato com porosidade de $0,6 \mu \mathrm{m}$. O filtro é tingido com acridina laranja e enumeradas por microscopia epifluorescênte. Pettipher e Osmundson detectaram grandes quantidades de bactérias esporofórmicas (> $5 \times 10^{5} \mathrm{UFC} / \mathrm{mL}$ ) em bebidas de frutas carbonatadas com o uso da técnica DEFT.

\subsubsection{Métodos de detecção rápida}

A identificação convencional de Alicyclobacillus spp. utiliza testes morfológicos e bioquímicos, e usualmente requer vários dias para realizá-lo dependendo do procedimento do isolamento. O método de reação em cadeia da 
polimerase (PCR) é amplamente utilizado no estudo da evolução molecular e são aplicadas para identificação de $A$. acidoterrestris (CERNY, 2000; MURAKAMI, 1998).

A transcrição reversa da reação em cadeia da polimerase (RT-PCR) foi usada para detectar $A$. acidoterrestris utilizando primers para a identificação específica destas bactérias (YAMAZAKI, 1996). Utilizando os mesmos primers foi melhorada a sensibilidade na detecção de sucos de laranja em até 1 UFC/mL, com ajuda da RTPCR e eletroforese capilar com fluorescência induzida a laser e tecnologia microchips, comprovando que o controle da contaminação de $A$. acidoterrestris viáveis em suco de laranja ou outras bebidas podem ser realizados dentro de $24 \mathrm{~h}$ utilizando RT-PCR (FUNES-HUACCA, 2004).

Nestes últimos anos, têm se estudado novas técnicas de identificação de linhagens de Alicyclobacillus spp. para o seu controle de qualidade. A espectroscopia de infravermelho por transformada de Fourier (FT-IR) tem sido utilizada para discriminar, classificar e identificar vários microorganismos dentre eles linhagens de Alicyclobacillus em amostras de sucos de maça. Esta técnica fornece informação bioquímica em vários componentes da parede celular e do citoplasma, incluindo proteínas e peptídeos, polissacarídeos, peptidoglicanos, ácidos nucléicos e fosfolipídeos (LIN, 2005).

\subsubsection{Inibição de Alicyclobacillus spp.}

$\mathrm{Na}$ indústria de processamento de alimentos, os endoesporos representam uma forma de vidas mais difíceis de ser inativado, devido ao fato que demonstram uma grande resistência a elevadas temperaturas. Diversos estudos de inibição de esporos de $A$. acidoterrestris foram estudados em diferentes sucos de frutas ácidas. 
YAMASAKI e colaboradores (2000) utilizaram a nisina, polipeptídeo antimicrobiano produzido a partir de Lactococcus lactis, como inibidor do crescimento de $A$. acidoterrestris em bebidas ácidas. $O$ crescimento da bactéria foi inibido em concentrações de unidades inibidoras de 25-50 $\mathrm{IU} \mathrm{mL} \mathrm{m}^{-1}$ de nisina em suco de laranja e frutas mistas, mas não foi inibido adicionado $600 \mathrm{IU} \mathrm{mL}^{-1} \mathrm{em}$ bebida de maça.

Tratamento sob pressão e temperatura média também foram utilizados para a inibição de $A$. acidoterrestris em alimentos. Alta pressão hidrostática e baixa temperatura foram avaliadas, resultando nas reduções decimais na ordem de 3 a 5,5 $\log _{10} \mathrm{UFC} / \mathrm{mL}$ numa população inicial de $10^{6} \mathrm{UFC} / \mathrm{mL}$ de Bacillus subtillis no leite, Bacillus cereus na carne e Alicyclobacillus spp. em sucos de tomate e maça (SHEARER, 2000).

Outro inibidor isolado a partir de Enterococcus faecalis A-48-32, denominado enterosina AS-48, foi utilizado em concentrações de $2,5 \mathrm{\mu g} \mathrm{ml}^{-1}$, chegando a inibir totalmente o crescimento das $A$. acidoterrestris depois de $24 \mathrm{~h}$ de incubação a 37 ${ }^{\circ} \mathrm{C}$. Essas análises foram testadas em sucos de laranja e maça (GRANDE, 2005).

\subsubsection{Técnicas moleculares para a detecção de microorganismos}

Na tentativa de buscar métodos mais rápidos e sensíveis para a detecção de microorganismos em alimentos, diversos métodos foram desenvolvidos. Ensaios rápidos que usam técnicas imunoquímicas, hibridização e amplificação de ácidos nucléicos, oferecem maior sensibilidade e especificidade do que métodos baseados em cultura, além de permitir a redução do tempo para obtenção de resultados. Muitos métodos alternativos atingiram um elevado nível de automação, facilitando sua aplicação na detecção rotineira de microrganismos (NORTON, 2002). 
Dentre os métodos que podem atender às exigências anteriores, têm-se aqueles que empregam a tecnologia da amplificação do DNA cromossômico (PCRreação em cadeia da polimerase). Poucos desenvolvimentos têm revolucionado tantos campos quanto a PCR, a qual foi conceitualizado por Kary Mullis no inicio da década de 1980.

Os estudos genéticos moleculares utilizam uma variedade de técnicas para analisar os ácidos nucléicos (DNA e RNA). Dentre estas técnicas destacam-se as técnicas de amplificação de alvos-específicos como a PCR, PCR competitiva, transcrição reversa da PCR (RT-PCR) e a PCR em tempo-real (rt-PCR). As técnicas moleculares também podem ser empregadas na determinação de resistência antimicrobiana e no monitoramento de contaminação de alimentos (ATKINS, 2004).

\subsubsection{Reação em Cadeia da Polimerase (PCR)}

A reação em cadeia da polimerase $(\mathrm{PCR})$ é uma das técnicas mais empregadas nas diversas áreas do diagnóstico molecular. A sua introdução resultou uma grande revolução tecnológica, permitindo a amplificação de uma seqüência de interesse contida em uma amostra complexa de DNA e possibilitou a adoção de métodos automatizados para a análise do genoma. A tecnologia da reação em cadeia da polimerase também é bastante flexível, permitindo uma série de modificações que possibilitam o seu emprego na análise de uma grande variedade de amostras.

A PCR é um processo enzimático, in vitro, para amplificação de uma seqüência específica de ácido desoxirribonucléico (DNA) (FARBER, 1996). Brevemente, dois primers específicos (pequenos fragmentos de DNA fita simples, com orientações opostas) flanqueiam a seqüência de DNA a ser amplificada e, pela 
ação da enzima DNA polimerase, sintetizam uma cópia da região do DNA delimitada por eles. A reação envolve 3 etapas: (i) desnaturação do DNA molde em uma fita simples, (ii) intercalação ou hibridização dos primers às regiões complementares ao DNA molde, e (iii) extensão e síntese do fragmento de DNA. Este ciclo é repetido de 20 a 40 vezes, sendo que cada novo fragmento sintetizado serve como um molde nos ciclos subseqüentes resultando em um aumento exponencial no número de cópias da região do DNA alvo (FARBER, 1996). A principal vantagem da aplicação de métodos baseados na amplificação de DNA é a estabilidade destas seqüências que não são afetadas por condições ambientais ou de cultivo.

Entre as principais técnicas resultantes de modificações da reação em cadeia da polimerase, podemos citar a RT-PCR, nested PCR, nested RT-PCR, multiplex PCR, PCR a partir de primers aleatórios (RAPD) e PCR em tempo real. O RT-PCR utiliza uma enzima chamada transcriptase reversa para converter uma amostra de RNA em cDNA antes da etapa de amplificação por PCR, permitindo estudo de vírus de RNA ou RNA de microorganismos viáveis em análises de expressão gênica.

O nested PCR, que emprega uma segunda etapa de amplificação com um par de primers internos aos utilizados na primeira etapa e visa aumentar a sensibilidade e especificidade do método. Já PCR multiplexado é uma reação de amplificação desenhada para detectar múltiplas seqüências-alvo numa mesma amostra. PCR a partir de primers randômicos utiliza seqüências curtas de oligonucleotídeos para amplificar regiões repetitivas do DNA genômico e é bastante empregado em estudos epidemiológicos. Finalmente, PCR em tempo real permite que a amplificação e a detecção ocorram simultaneamente, num sistema fechado, sendo necessário para isto um termociclador que possua sistema de monitoramento de emissão de fluorescência (BOXER, 2000). 


\subsubsection{Métodos eletroforéticos para diagnóstico molecular}

A observação dos resultados de testes em diagnóstico molecular, envolve inspeção visual da separação dos resultados em um gel de agarose ou poliacrilamida. A separação eletroforética nestas circunstâncias, fornece a informação do tamanho dos fragmentos de ácidos nucléicos e sua execução leva entre 1 a $2 \mathrm{~h}$ em géis de agarose e até $8 \mathrm{~h}$ para separações com gel de poliacrilamida de alta resolução, e com tecnologia de eletroforese capilar tem reduzido este tempo imensamente.

Como o progresso da microfluídica, novos sistemas de eletroforese capilar baseada em Lab-on-a-chip tem sido reportados. O novo equipamento chamado Bioanalyzer 2100 (Agilent Technologies, Alemanha) separa e detecta fragmentos de DNA, RNA e proteínas, pela aplicação de eletroforese capilar (CE) com detecção de fluorescência induzida a laser (LIF).

\subsubsection{Eletroforese capilar em microchip com detecção por fluorescência a laser} (LIF)

A tecnologia microchips também chamada como lab-on-a-chip oferece plataformas altamente eficientes para análise simultânea de moléculas biologicamente importantes, possuindo grande potencial para estudos genômicos e proteômicos. A implementação e desenvolvimento de ferramentas bioanalíticas baseada em microfluídica envolvem tecnologias já estabelecidas, incluindo sistemas de microlitografía, micromaquinaria, microeletroquímica e de nanotecnologia (KHANDURINA, 2002).

A separação de ácidos nucléicos em microchips é uma das principais aplicações de análise eletroforética, devido ao seu melhor rendimento, rapidez e 
reduzido custo no consumo de reagentes, comparado à eletroforese de gel em placa e capilar. As separações rápidas em chips de alta qualidade foram demonstradas para análises de fragmentos de oligonucleotídeos, RNA e DNA, assim como aplicações de genotipagem e seqüenciamento. Tipicamente, a fluorescência induzida a laser (LIF) é utilizada para a detecção, mas outros métodos tais como espectrometria de massa (MS) e detecção eletroquímica também já foram investigadas (KHANDURINA, 2002).

A eletroforese capilar com detecção por fluorescência a laser (CE - LIF) é uma técnica eficiente e precisa, a qual utiliza o poder de separação da eletroforese capilar (CE) para separação de fragmentos de DNA sendo posteriormente detectados por fluorescência a laser.

As amostras de DNA são automaticamente analisadas com deteç̧ão LIF ao serem injetadas em um microchip (ou dispositivo de microfluídica) e inseridas no equipamento comercialmente chamado Bioanalyzer 2100, (Agilent Technologies, Alemanha), mostrado na Figura 1.1. Este equipamento analisa 12 amostras por chip em torno de $30 \mathrm{~min}$.

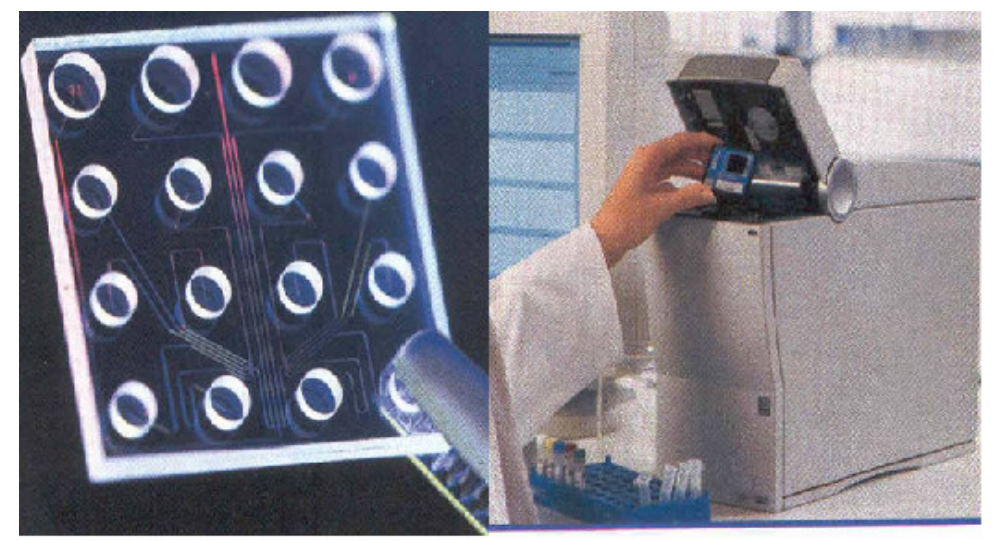

Figura 1.1: Eletroforese no Lab-on-a-Chip Agilent 2100 Bioanalyzer. 
Aplicações de PCR-RFLP no Bioanalyzer 2100 foram desenvolvidas na identificação de diferentes espécies de peixes em alimentos processados, quando combinadas as enzimas de restrição Nlalll e Haelll, perfis específicos de dez espécies foram geradas. O método foi aplicado em diferentes produtos e submetido a um estudo interlaboratorial executado por cinco laboratórios de controle de alimentos no Reino Unido (DOOLEY, 2005).

Também a tecnologia microchips foi utilizada para diferenciar espécies de parasitas Cyathostomin. C. elongatus e C. insigne, utilizando PCR-RAPD e o Bioanalyzer 2100. As análises dos dados eletroforéticos foram otimizadas e foi possível realizar uma árvore filogenética a partir de doze espécies de larvas (POSEDI, 2003).

\subsubsection{Filogenia molecular para classificação bacteriana}

A filogenia consiste na identificação e entendimento das relações entre as espécies que resultam da evolução. Sob a premissa que as espécies evoluem de um ancestral comum, as espécies mais próximas têm mais características em comum do que as mais distantes. Porém a sistemática filogenética é utilizada para identificar características similares e definir a relação histórica ou evolucionaria com base nessas características, incluindo genes ou fragmentos de DNA. Com base nessas relações, árvores filogenéticas são desenvolvidas mostrando as relações evolucionarias ou agrupamento de organismos.

As técnicas de DNA recombinante também são úteis para classificar organismos segundo a sua filogenia. Esses estudos podem ser realizados estudando a seqüência total de nucleotídeos do genoma do microorganismo, mas atualmente se utilizam os estudos do $16 \mathrm{~S}$ rRNA ou $18 \mathrm{~S}$ rRNA porque são 
seqüências que se mantiveram bastante conservadas ao longo da evolução, e por isso observamos as diferenças entre os diferentes microorganismos; porem podem se realizar árvores filogenéticas e esquemas evolutivos (BUSO, 2005).

Para trabalhar com filogenética baseada em dados moleculares é preciso conhecer algumas propriedades das seqüências a serem comparadas. Primeiramente, elas devem ser homólogas, ou seja, apresentar uma ancestralidade comum. Uma vez obtidas as seqüências, estas devem ser alinhadas corretamente. Para tal, apesar de haver muitos programas computacionais que realizam essa tarefa, as seqüências devem ser alinhadas manualmente. Entretanto, alinhamento automático pode ser um primeiro passo. Essa etapa é de extrema importância, pois um alinhamento errado comprometerá toda a análise.

Em todas as metodologias de filogenética molecular, cada posição ocupada na seqüência (nucleotídeo ou aminoácido) é considerada como um caráter do tipo multi-estado (podendo ser um dos quatro nucleotídeos ou um dos vinte aminoácidos) e cada caráter é considerado independente dos demais. A variação dos estados de caracteres fornecerá informações filogenéticas. Metodologias filogenéticas são essencialmente estatísticas e podem ser classificadas em dois grupos principais, de acordo com seus critérios: quantitativos (métodos de distância) e qualitativos (métodos de parcimônia e verossimilhança) (MATIOLI, 2001).

Nos métodos de distância, as diferenças entre duas seqüências são reduzidas a uma só variável (número de diferenças) e suas relações evolutivas não são consideradas. Nesse método, primeiramente calcula-se a distância, para, a seguir, construir a árvore filogenética, utilizando um algoritmo específico. Existem diferentes modelos que podem ser utilizados para a construção de uma matriz de distância (NEI, 2000; MATIOLI, 2001). A partir dessa matriz será reconstruída a 
árvore com um dado algoritmo, sendo os mais utilizados o UPGMA (Unweighted Pair Group Method with Arithmetic Mean) e o neighbor joining.

Assim, a determinação correta da taxonomia dentro do gênero é um fator essencial para que se possa chegar a generalizações e conclusões acerca da ecologia e fisiologia relacionadas a qualquer microorganismo, uma vez que a falta de linhagens bem definidas causa grandes equívocos na comparação de diversos casos estudados. No nosso caso, várias "espécies" do gênero Alicyclobacillus já foram responsabilizadas pelas contaminações de sucos nas indústrias cítricas, e por isso é importante realizar um estudo exaustivo de identificação e classificação filogenética destas bactérias utilizando métodos moleculares e ferramentas de bioinformática

\subsection{OBJETIVOS}

> Incrementar o conhecimento genético microbiológico das Alicyclobacillus acidoterrestris com a utilização de ferramentas moleculares e de bioinformática para o seu estudo.

> Estudar um método analítico sensível, com técnicas moleculares e eletroforéticas, na detecção de $A$. acidoterrestris viáveis para melhorar o controle de qualidade na indústria cítrica.

$>$ Monitorar as condições de crescimento e inibição de $A$. acidoterrestris frente a inibidores naturais e temperatura utilizando técnicas moleculares para o seu controle. 
Analisar a classificação de diversos isolados de Alicyclobacillus spp, para estudar as diferentes linhagens encontradas em sucos e frutas ácidas por meio de técnicas de RAPD, eletroforese em microchips, e seqüenciamento. 
CAPÍTULO 2: DETECÇÃO DE Alicyclobacillus acidoterrestris EM SUCOS DE LARANJA POR RT-PCR E NESTED RT-PCR UTILIZANDO MÉTODOS ELETROFORÉTICOS DE ANÁLISE 


\subsection{INTRODUÇÃO}

Na indústria, a contagem de $A$. acidoterrestris em sucos de laranja é realizada aproximadamente em oito dias de análise, utilizando técnicas microbiológicas tradicionais. Tipicamente, amostras pasteurizadas são diluídas e enriquecidas a 45 ${ }^{\circ} \mathrm{C}$ por três dias e depois, alíquotas da cultura enriquecida são analisadas por técnicas de contagem em placas e incubadas a $45^{\circ} \mathrm{C}$ por cinco dias. Geralmente, sucos concentrados apresentam contaminação nas concentrações de $1 \times 10^{3}$ até 10 $\mathrm{UFC} / \mathrm{mL}$.

Métodos moleculares oferecem uma rápida, sensível e específica detecção de bactérias. Os DNA e RNA são comumente analisados usando métodos de amplificação molecular, tais como a Reação em Cadeia da Polimerase (PCR) e a transcrição reversa de PCR (RT-PCR). O RNA ribossomal (rRNA) por sua vez, pode ser considerado como uma ótima molécula alvo em análises para detecção de patógenos em alimentos contaminados, devido ao seu alto número de cópias produzidas, e conseqüente melhora significativa no limite de detecção. Diversos estudos têm mostrado que o estado dos ribossomos é um indicador biológico sensível do estado fisiológico das células, e que o rRNA pode estar correlacionado com a viabilidade celular (ROSENTHAL, 1970; ROSENFIELD, 1998; McKILLIP, 1998).

Diferentes regiões no gene 16S rRNA têm variabilidade extremamente baixa e extremamente alta, simultaneamente, e são denominadas como regiões universais (U) e regiões variáveis $(\mathrm{V})$, respectivamente. O 16S rRNA procariótico conta com 8 regiões universais (U1-U8) e 9 regiões variáveis (V1-V9) (GRAY, 1984). Um par de primers específicos é selecionado da região variável V2 e V4 do gene 16S rRNA, e 
esses serão utilizados para a detecção de $A$. acidoterrestris viáveis em bebidas ácidas (YAMAZAKI, 1996).

No presente capítulo, descreveremos o desenvolvimento de um método de transcrição reversa da reação em cadeia da polimerase (RT-PCR) e nested RTPCR, visando incrementar a sensibilidade na detecção de microorganismos viáveis presente nos sucos de laranja. Assim, utilizaremos métodos de eletroforese capilar em gel com detecção de fluorescência induzida a laser, para a quantificação dos produtos de RT-PCR e nested RT-PCR produzidos para cada amostra de suco de laranja inoculado com a bactéria. Como parte complementar neste capítulo, também realizaremos uma aplicação específica de RT-PCR e nested RT-PCR para estudar e monitorar o grau de viabilidade dos esporos de $A$. acidoterrestris inativados em contato com temperaturas elevadas e com frações purificadas de Sapindus saponaria.

\subsubsection{Métodos Quantitativos em RT-PCR}

Um dos aspectos mais importantes das análises de RT-PCR está na separação e detecção de produtos de PCR (amplicons). A maioria das técnicas analíticas para análise de produtos de PCR é a eletroforese em gel de agarose com brometo de etídeo. No entanto, esta técnica apresenta algumas desvantagens sobre a eletroforese capilar (CE), tais como: alto consumo de amostra e reagentes, baixa resolução, exposição a reagentes tóxicos e as análises não são facilmente automatizadas.

A metodologia da detecção semi-quantitativa utiliza métodos de diluições como uma maneira rápida e sensível para a detecção e contagem em culturas 
puras, alimentos e em amostras ambientais. Este método permite a quantificação de alvos, que é capaz de estimar o número correspondente de células (Li, 2001).

A PCR em tempo real (rt) é uma técnica cinética que realiza a detecção de produtos de PCR ciclo-a-ciclo para sua quantificação, usando métodos de fluorescência ou fluorescência de ressonância por transferência de energia. Além, de fornecer resultados quantitativos mais precisos em diferentes amostras, o real time PCR ainda não é amplamente utilizada, devido ao custo considerável e ao desenho específico de reagentes e instrumentação (BUSTIN, 2000).

O Bioanalyzer 2100 (Agilent Technologies) é um dos primeiros sistemas comerciais que utiliza tecnologia baseada em chips para a separação de ácidos nucléicos. As amostras são adicionadas em orifício do suporte que contém um chip de vidro com canais microfabricados. Usando este instrumento, amostras de ácido nucléico são automaticamente separadas e analisadas por CE com detecção de fluorescência induzida a laser (LIF) (NACHAMKIM, 2001).

A estrutura do microchip consiste de microcanais interconectados, construídos por técnicas de microfabricação. A separação do fragmento de DNA pode ser realizada dentro do microcanal, no qual são preenchidos com um polímero e um corante fluorescente. A mobilidade do DNA a través dos microcanais é efetuada por eletrodos, o qual cria forças eletrocinéticas capazes de empurrar os fluidos e moléculas de DNA. A regulação automatizada da alta voltagem, entre os 16 eletrodos de platina, controla a velocidade e direção do movimento do fluido. Com a diferença de potencial aplicada, fragmentos de DNA de diferentes tamanhos, intercalados com corante fluorescente são separados segundo sua massa e podem ser detectados por um detector a laser (PANARO, 2000). 
Os dados quantitativos apresentados pelo equipamento Bioanalyzer 2100 são apresentados em concentração de DNA (ng/ $\mu \mathrm{L})$, molaridade (nmol/L), área do pico e tamanho do fragmento (bp). A concentração é calculada a partir da relação área/concentração do marcador superior (upper) fornecido pelo próprio kit. Os experimentos são analisados e calculados usando o próprio software do equipamento Agilent biosizing (version A.02.12) (PANARO, 2000).

\subsubsection{Diagnóstico e precisão analítica em PCR}

Os métodos baseados em PCR têm um alto grau de precisão analítica no diagnóstico. A precisão analítica inclui o limite de detecção e a seletividade, definida como uma medida do grau de resposta de microorganismos alvos e não alvos utilizando cepas puras.

A precisão no diagnóstico considera microorganismos alvos e não alvos na presença de uma matriz biológica e inclui os termos de especificidade e sensibilidade. A especificidade no diagnóstico é definida como uma medida do grau para o qual o método é afetado por componentes não alvos presentes em uma matriz biológica, que pode resultar em respostas falsas positivas. No caso da sensibilidade no diagnóstico de patógenos, é definida como uma medida do grau para detectar alvos patogênicos na matriz biológica, o qual pode resultar em respostas falsas negativas. Portanto, a precisão no diagnóstico é usada para avaliar a proximidade de concordância entre resultados de um método baseado em PCR e a referência aceita por métodos tradicionais. (MALORNY, 2003).

Durante a última década, vários métodos de PCR foram estabelecidos para a detecção de bactérias contaminantes ou patogênicas e vírus em diferentes matrizes de alimentos e água. Dependendo das circunstâncias específicas, tais como; região 
do gene, sistema de detecção e tipo de alimento, os limites de detecção obtidos em varias reações de PCR variaram entre 10 e $10^{4}$ UFC/g de alimento. No entanto, a sensibilidade não só depende do sistema de detecção, mas também da constituição da matriz do alimento a ser analisada. Por exemplo, o queijo é uma matriz extremamente problemática, com um limite de detecção que atinge até $2 \times 10^{8}$ UFC/g, devido a presença de inibidores na PCR. (SCHEU, 1998).

Entretanto, o limite de detecção deve ser determinado em relação a um cálculo de probabilidade de detecção (KNUTSSON, 2002). Assim, a freqüência relativa esperada de uma resposta positiva de PCR, a diferentes concentrações de ácidos nucléicos alvos ou células, deve ser estabelecida. A aplicação direta de PCR para alimentos precisa de métodos eficazes para a separação de células bacterianas a partir de amostras de alimentos. Esses métodos idealmente devem possuir o número menor possível de passos, a capacidade para remover completamente os inibidores da PCR, e um alto potencial para a conversão em um formato automatizado (LANTZ, 2000).

\subsubsection{Sensibilidade na detecção por nested PCR}

A técnica de nested PCR consiste em duas reações de PCR sucessivas com dois pares de primers diferentes, de tal modo que, os primers utilizados na segunda PCR (nested PCR) intercalem uma região genômica amplificada na primeira reação em cadeia (PCR), como ilustra a Figura 2.1.

O método nested PCR utiliza-se quando se têm pequenas quantidades de DNA de interesse ou quando se requer evitar amplificações não específicas que às vezes se observam com a PCR clássica. Se o produto da primeira PCR for um amplicon inespecífico, o segundo par de primers não reconhecerá a seqüência 
complementar, e por tanto, não terá amplificação positiva. Este procedimento incrementa a sensibilidade dos ensaios pela reamplificação do produto da primeira reação em uma segunda reação. A especificidade da análise é incrementada porque os primers internos amplificam somente se a primeira reação produziu um produto específico.

A técnica de nested RT-PCR é uma poderosa técnica de diagnóstico para determinar a presença ou ausência de vírus ou tumores celulares com extrema sensibilidade. Em aplicações de diagnóstico clínico, a sensibilidade pode ser melhorada com a técnica nested RT-PCR quantitativo competitivo, que utiliza um padrão interno de RNA competitivo. No entanto, a síntese do competidor interno é laborioso, requerindo-se o uso de vetores de clonagem e técnicas de deleção (O’CONNELL, 2002).

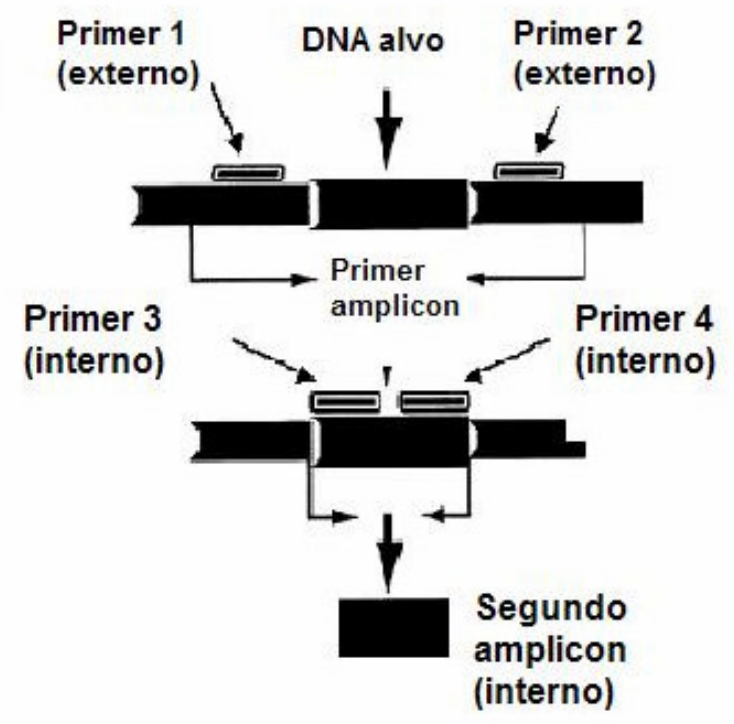

Figura 2.1: Diagrama para reação de nested PCR na amplificação específica de um alvo de DNA para reação nested PCR. 


\subsubsection{Atividade antibacteriana sobre Alicyclobacillus acidoterrestris}

A inibição de $A$. acidoterrestris em sucos de frutas tem sido regulada pelo peptídeo antibacteriano nisina, obtida a partir do Lactococcus lactis sp. Lactis (KOMITOPOULOU, 1999). Outros agentes antibacterianos, como o hipoclorito de sódio e a lisozima, mataram e reduziram, respectivamente, os esporos de $A$. acidoterrrestris (ORR, 2000).

Outros peptídeos inibidores do crescimento da $A$. acidoterrestris, $\alpha$ e $\beta$ tioninas, foram isolados dos grãos de cevada e trigo. As tioninas consistem em 45 aminoácidos que inibem o crescimento de outras bactérias Gram positivas (OTTA, 2002).

A utilização de agentes bactericidas a partir de produtos naturais está crescendo nos últimos anos. Por isto, a inibição de $A$. acidoterrrestris pelo tratamento com substâncias antibacterianas extraídas de produtos naturais tais como saponinas (Sapindus saponaria), serão estudados como parte complementar da nossa pesquisa.

\subsubsection{Atividade antimicrobiana de saponinas}

Saponina é o nome genérico dado a uma classe de glicosídeos formados por uma aglicona com esqueleto de triterpeno, esteróide ou alcalóide esteroidal a qual está ligada a uma ou duas cadeias de açúcar. Devido ao fato de possuírem regiões lipofílica (aglicona) e hidrofílica (açúcares) na mesma molécula, são denominadas anfifílicas e, quando dissolvidas em água, tendem a formar micelas. Estas provocam uma diminuição na tensão superficial da solução e melhoram a solubilidade de compostos hidrofóbicos em água (OLESZEK, 2002). 
Sapindus saponaria é uma árvore da família sapindaceae encontrada nos trópicos do Brasil e a Índia, onde seus frutos são utilizados como sabão devido ao alto teor de saponinas (LEMOS, 1992). A Sapindus saponaria pode ser considerada uma importante fonte para obtenção de saponinas, já que esta árvore é encontrada em grande parte do país e produz uma grande quantidade de frutos com alto percentual de saponinas. A figura 2.2 mostra a estrutura de algumas saponinas isoladas da planta Sapindus saponaria.

$$
\begin{aligned}
& \text { R } \\
& -\operatorname{Ara}(\mathrm{p}) \stackrel{2}{-} \mathrm{Rha}-\frac{3}{-} \operatorname{Ara}(\mathrm{p}) \\
& -\operatorname{Ara}(\mathrm{p}) \stackrel{2}{-} \mathrm{Rha}-\frac{3}{-} \mathrm{xyl} \\
& -\operatorname{Ara}(\mathrm{p}) \stackrel{2}{-} \mathrm{Rha} \stackrel{3}{-} \mathrm{Xyl} \stackrel{4}{-} \mathrm{Ac} \\
& -\operatorname{Ara}(\mathrm{p}) \stackrel{2}{-} \mathrm{Rha}-\frac{2}{2} \mathrm{Xyl} \underset{4}{\frac{3}{\mathrm{AC}} \mathrm{AC}} \\
& \text { - Glc } \stackrel{6}{-} \text { Rha } \frac{3}{-} \operatorname{Ara}(p) \\
& \text { - Glc } \stackrel{3}{-} \mathrm{Rha}
\end{aligned}
$$

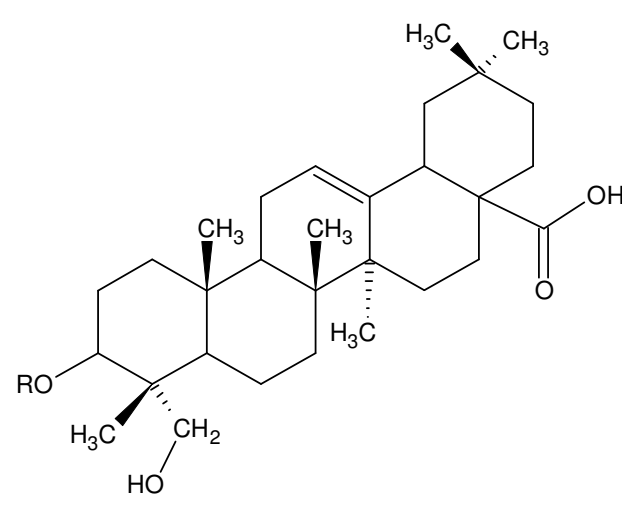

$\operatorname{Ara}(p)$ : $\alpha$-arabinopiranosil; Ara(f): $\alpha$-arabinofuranosil; Glc: $\alpha$-D-glicopiranosil; Rha: $\alpha$-L-ramnopiranosil; Xyl: $\alpha$-D-xilopiranosil; Ac: O-acetil.

Figura 2.2: Saponinas isoladas de Sapindus saponaria (MURGU, 2006).

\subsubsection{Métodos de extração e purificação de saponinas}

Sendo glicosídeos, e por tanto, substâncias polares, as saponinas são geralmente solúveis em água e pouco solúveis em solventes apolares. O extrato aquoso apresenta como vantagem, além do custo menor, a ausência de lipídeos e clorofila. No entanto, como desvantagens devem ser consideradas as possibilidades 
de hidrólise, durante o processo extrativo, ou ainda a hidrotermólise, no caso de extração a quente, devido a baixa estabilidade desses extratos. De modo geral, são utilizados álcoois, etanol ou metanol, ou misturas hidroalcoólicas para a extração, através de maceração, decocção, percolação ou extração exaustiva sob refluxo. Freqüentemente, o extrato hidroalcoólico assim obtido é submetido à purificação, após eliminação do conteúdo alcoólico, através da partição com solvente pouco polar (diclorometano ou clorofórmio) para a retirada de composto apolares, seguida da partição com n-butanol, para a eliminação de açúcares livres, aminoácidos e ácidos orgânicos.

Outros métodos de purificação incluem a complexação com colesterol, diálise, cromatografia de troca iônica ou extração seletiva utilizando a formação de sal, quando na presença de saponinas ácidas, bem como métodos cromatográficos, utilizando resinas sintéticas, gel de sílica ou géis de exclusão molecular, tipo Sephadex (HOSTETTMANN, 1995).

\subsubsection{Propriedades biológicas de saponinas}

O comportamento anfifílico das saponinas e a capacidade de formar complexos com esteróides, proteínas e fosfolipídeos de membranas determinam um número variado de propriedades biológicas para essas substâncias. Destaca-se a ação sobre as membranas celulares, onde a sua permeabilidade é alterada, causando sua destruição. As membranas das células da parede intestinal, ao contato com as saponinas, se fazem mais permeáveis permitindo uma melhor absorção dos nutrientes, além de acelerar a atividade microbiana da flora intestinal, melhorando a digestão e o aproveitamento dos alimentos (SIMÕES, 1999). 
Estas moléculas possuem a capacidade de precipitar o colesterol; quando estão próximas das membranas celulares interagem com o colesterol criando estruturas semelhantes a poros que podem causar a ruptura da membrana. Apresentam uma grande diversidade de atividades biológicas tais como: antibactericida, antiviral, antifúngica, moluscicida, antitumoral, entre outras (HOSTETTMANN, 1995).

A ingestão diária de saponinas presentes na ampla variedade de alimentos varia de acordo com a dieta do indivíduo. Pesquisas sobre seu consumo na dieta de uma pessoa normal foram calculadas em média $15 \mathrm{mg}$ por dia e, no caso de vegetarianos chegam a consumir diariamente $110 \mathrm{mg}$. Felizmente, a toxicidade via oral de saponinas para animais de sangue quente é relativamente baixa, estando os valores de dose letal na faixa de 50 a 1000 mg/kg. (OAKENFUL, 1981). A razão para que este fenômeno apresente um baixo risco é a baixa absorção de saponinas pelo corpo.

As saponinas extraídas da alfafa e ginseng para o consumo humano, foram intensamente pesquisadas. Ratos alimentados com saponinas de alfafa em níveis de $1 \%$ na dieta por seis meses, não mostraram sintomas de hipercolesteromia e arteriosclerose, embora uma redução potencialmente benéfica de colesterol e triglicerídeos foram observadas (MALINOW, 1981).

O princípio geral da ação de saponinas em microorganismos é sua interação com as membranas esteroidais, resultando uma significante perda na atividade vital do organismo, especialmente em microorganismos Gram-positivos tal como Bacillus sp. O grau de atividade depende da estrutura da saponina e do microorganismo alvo, chegando a inibir em bactérias Gram positivas com concentração de inibição mínima (MIC) de 0,3 - 1,25 mg/mL, e em Gram-negativas de 1,25 - $5 \mathrm{mg} / \mathrm{mL}$ 
respectivamente. As saponinas podem ser encontradas em muitas plantas e utilizadas como alimento para humanos, devido a que não são absorvidos no trato digestivo e não criar sérios problemas toxicológicos (OLESZEK, 2000).

\subsection{OBJETIVOS}

$>$ Quantificar de maneira simples e rápida $A$. acidoterrestris viáveis por RT-PCR em sucos de laranja, usando a tecnologia de microchips.

> Desenhar e otimizar primers internos específicos da região variável do gene $16 \mathrm{~S}$ rRNA das $A$. acidoterrestris para reações de nested PCR.

$>$ Estudar o limite de detecção de $A$. acidoterrestris inoculados em meio de cultura YGS e sucos de laranja por reações RT-PCR e nested PCR.

> Monitorar o poder de inibição das saponinas de $S$. saponaria em diferentes concentrações e tempos de incubação nos sucos de laranja utilizando a RTPCR e nested RT-PCR.

\subsection{MATERIAIS E MÉTODOS}

\subsubsection{Linhagem e meio de cultura}

A cultura de Alicyclobacillus acidoterrestris utilizada neste estudo foi fornecida pela empresa de sucos de laranja CARGILL AGRíCOLA S.A. e reproduzida no laboratório em amostra de suco de laranja. As bactérias de Alicyclobacillus acidoterrestris cresceram a $45^{\circ} \mathrm{C}$ no meio de cultura YGS (yeast glucose starch) contendo extrato de levedura $2,0 \mathrm{~g}$, glicose $1,0 \mathrm{~g}$, amido solúvel 2,0 g, água destilada $500 \mathrm{~mL}$. $\mathrm{O} \mathrm{pH}$ foi ajustado até $3,7 \mathrm{com} \mathrm{H}_{2} \mathrm{SO}_{4}$. 
A produção de esporos de $A$. acidoterrestris foi realizada por incubação a 45 ${ }^{\circ} \mathrm{C}$ durante 5 dias. Os esporos foram removidos e lavados por centrifugação com água acidificada autoclavada. Finalmente os pellets foram ressuspendidos em tampão ácido (pH 3,7).

Os testes de contagem total em placas no meio YGS, além de servirem para a quantificação dos sucos inoculados antes da extração dos ácidos nucléicos também é um teste muito utilizado nos laboratórios microbiológicos das indústrias cítricas e será possível comparar satisfatoriamente o método empregado pelas indústrias com o proposto neste trabalho.

\subsubsection{Sensibilidade nas reações de RT-PCR}

Para determinar a sensibilidade da detecção das bactérias $A$. acidoterrestris, realizaram-se diluições seriadas de $2 \times 10^{5} \mathrm{UFC} / \mathrm{mL}$ até $2 \mathrm{UFC} / \mathrm{mL}$ de células em meio líquido de YGS (yeast, glicose, starch) e incubadas a $45^{\circ} \mathrm{C}$ por 0 e 12 horas. Simultaneamente, amostras de sucos de laranja foram inoculadas com $A$. acidoterrestris em diferentes concentrações.

\subsubsection{Isolamento do DNA}

Foi coletado $1 \mathrm{~mL}$ dos meios contaminados antes e depois da incubação, lavaram-se as células com tampão $1 \times$ PBS, e em seguida foram centrifugadas. A partir desta suspensão de células, foi extraído o DNA genômico usando o kit EasyDNA $^{\mathrm{TM}}$ (Invitrogen), segundo as instruções do protocolo do kit. As amostras foram tratadas com $1 \mu \mathrm{l}$ de RNase A, e finalmente suspendeu-se em $70 \mu \mathrm{L}$ de água livre de DNase. 


\subsubsection{Isolamento do RNA}

Todo o material de vidraria para o preparo de reagentes na extração de RNA foi esterilizado à $180^{\circ} \mathrm{C}$ por $12 \mathrm{~h}$ em estufa. Todos os reagentes foram preparados com solução $0,1 \%$ de $\mathrm{H}_{2} \mathrm{O}$-DEPC (dietilpirocarbonato) e logo esterilizados antes de serem usados.

O RNA foi extraído das amostras de sucos e meios inoculados com $A$. acidoterrestris $(1 \mathrm{~mL})$ antes e depois das $12 \mathrm{~h}$ de incubação à $45^{\circ} \mathrm{C}$. A extração foi realizada com o reagente Trizol (Invitrogen) e os pellets de RNA foram suspendidos em $70 \mu \mathrm{L}$ de $\mathrm{H}_{2} \mathrm{O}$-DEPC. Finalmente, os RNA foram tratados com $1 \mathrm{U}$ de DNase I (Invitrogen) por 20 min à $30^{\circ} \mathrm{C}$, depois a enzima foi inativada à $65^{\circ} \mathrm{C}$ por 15 min.

\subsubsection{Transcrição reversa da RT-PCR}

Para as reações de RT-PCR, primers específicos foram desenhados a partir da seqüência do 16S rRNA (YAMASAKI, 1996). Os primers sintetizados têm um produto amplificação de 294 bp (Tabela 2.1). O passo da transcrição reversa (RT) para gerar o cDNA (DNA complementar) foi realizado num volume final de $20 \mu \mathrm{L}$ utilizando-se i) $0,1 \mu \mathrm{g}$ de RNA total previamente digerido com DNase I $(0,5 \mu \mathrm{M})$, ii) primer antisense $(1 \mu \mathrm{M})$, logo desnaturados à $70^{\circ} \mathrm{C}$ por $5 \mathrm{~min}$, e imediatamente resfriados para acrescentar ao mix da RT $(2,0 \mathrm{mM}$ dNTP, $3 \mathrm{mM} \mathrm{MgCl} 2,1 \times$ tampão RT) e iii) $1 \mu \mathrm{L}$ da enzima transcriptase reversa, Improm-II ${ }^{\mathrm{TM}}$ (Promega). A mistura foi incubada à $25^{\circ} \mathrm{C} / 5 \min , 40^{\circ} \mathrm{C} / 60 \min$ e $70^{\circ} \mathrm{C} / 15 \min$.

Uma vez sintetizado o cDNA, realizou-se uma reação de PCR no volume final de $13 \mu \mathrm{L}$; contendo $1 \times$ PCR tampão, $1,5 \mathrm{mM} \mathrm{MgCl}$, 0,2 mM dNTP, $1 \cup$ Taq-DNA polimerase (Invitrogen), $1 \mu \mathrm{M}$ de cada um dos primers e $3 \mu \mathrm{L}$ do cDNA. 
As condições do ciclo foram as seguintes: desnaturação inicial à $94{ }^{\circ} \mathrm{C} / 4 \mathrm{~min}$, seguida de 35 ciclos de desnaturação à $94{ }^{\circ} \mathrm{C} / 1 \mathrm{~min}$, pareamento de $54{ }^{\circ} \mathrm{C} / 30 \mathrm{~s}$, extensão à $72{ }^{\circ} \mathrm{C} / 30$ s e uma extensão final à $72^{\circ} \mathrm{C} / 7 \mathrm{~min}$. Todas as reações de RTPCR foram analizadas por triplicata, realizadas no termociclador PTC-100 da MJ Research.

As reações de PCR foram realizadas com as amostras de DNA $(0,1 \mu \mathrm{g})$ extraídas das culturas, e as mesmas condições de concentração de reagentes e de ciclos foram utilizadas para uma comparação direta.

Tabela 2.1: Seqüência dos primers específicos dos Alicyclobacillus acidoterrestris (YAMASAKY, 1996)

\begin{tabular}{lll}
\hline Primers & Seqüência & Tamanho \\
\hline Ba 190F & 5' AC(A/G)GGGTAGGCATCTCTTGT 3' & \\
Ba 490R & 5' AGGAGCTTTCCACTCTCCTTGT 3' & 294 bp \\
\hline
\end{tabular}

\subsubsection{Desenho de primers para testes de nested RT-PCR em A. acidoterrestris}

Os primers utilizados nas reações nested RT-PCR foram desenhados a partir do produto amplificado da primeira reação de RT-PCR (294 bp). Os fragmentos foram purificados com o kit SV gel PCR clean-up System (Promega ${ }^{\mathrm{TM}}$ ) e posteriormente sequenciados no ABI PRISM 3100 Avant Genetic Analyzer (Applied Biosystems), para a confirmação da seqüência de Alicyclobacillus acidoterrestris. As análises de seqüenciamento foram realizadas no laboratório de Biotecnologia Animal da CPPSE-EMBRAPA, seguindo o protocolo descrito no Capítulo 4 item 4.3.4.

Com a sequência obtida no $A B I P R I S M 3100$, foram desenhados os primers internos (nested) utilizando o Programa GeneRunner (Versão 3.05), considerando diferentes variáveis para o respectivo desenho (Tabela 2.2). As condições 
encontradas para a síntese dos primers foram: tamanho do produto 191 bp, temperatura ótima de fusão (Tm) foi de 59,2 e com \%GC de $61,8 \%$. Esses primers foram sintetizados pela Invitrogen (Invitrogen, Carlsbad, CA, EUA).

Para avaliar a especificidade dos primers nested, foram utilizados os controles A. acidoterrestris, A. acidocaldarius e A. cycloheptanicus. Primeiro foram realizadas as reações de RT-PCR com os primers listados na Tabela 2.1, e posteriormente alíquotas do primeiro produto (294 bp) foram utilizadas para as reações nested RTPCR com os primers desenhados (191 bp).

Tabela 2.2: Seqüência de primers nested desenhados para detecção de Alicyclobacillus acidoterrestris em reações nested RT-PCR.

\begin{tabular}{lll}
\hline Primers & Seqüência & Tamanho \\
\hline NAtb-F & 5' GATGCGTAGCCGACCTGAGAG 3' & \\
NAtb-R & 5' TTGCCACTCTCCTTGTCGCTC 3' & $191 \mathrm{bp}$ \\
\hline
\end{tabular}

\subsubsection{Otimização dos primers nested em reações nested PCR}

A otimização da PCR foi realizada no termociclador com gradiente de temperatura, testando-se a temperatura de anelamento que servirá para as reações posteriores de nested PCR e nested RT-PCR. A reação de otimização dos primers nested foi realizada na reação nested PCR em um volume final de $20 \mu \mathrm{L}$ com os seguintes reagentes: tampão de PCR 10×, $\mathrm{MgCl}_{2} 1,5 \mathrm{mM}$, dNTPs $20 \mathrm{mM}$, primer sense 1,0 $\mu \mathrm{M}$ e primer antisense 1,0 $\mu \mathrm{M}$, Taq-DNA polimerase $1 \mathrm{U}$ e $2 \mu \mathrm{L}$ do amplicon 294 bp produzido na primeira PCR.

A PCR foi realizada no termociclador modelo Mastercycler Gradient da Eppendorf por 35 ciclos a $94^{\circ} \mathrm{C}$ de desnaturação inicial por 4 min, desnaturação de 
$94{ }^{\circ} \mathrm{C} / 1$ min para desnaturação; as temperaturas de pareamento variaram de 48,4 até $67,5^{\circ} \mathrm{C} / 30 \mathrm{~s}, 72{ }^{\circ} \mathrm{C} / 30 \mathrm{~s}$ de extensão e uma extensão final de $72{ }^{\circ} \mathrm{C}$ por $7 \mathrm{~min}$. Os produtos amplificados na nested PCR foram analisados no gel de agarose $1,5 \%$ a $80 \mathrm{~V} \mathrm{~cm}^{-1}$ por 1 hora e $30 \mathrm{~min}$, apresentando um tamanho de produto amplificado de 191 bp. Também realizamos uma detecção e quantificação dos amplicons produzidos no Bioanalyzer 2100 (Agilent Technologies), com o kit DNA 500 LabChip $^{\circledR}$, para encontrar a temperatura que apresentou maior concentração do produto.

\subsubsection{Limite de deteç̧ão nas reações RT-PCR e nested RT-PCR}

O limite de deteç̧ão das reações nested RT-PCR na deteç̧ão de $A$. acidoterrestris foram realizados primeiro com as reações RT-PCR. As reações de RT-PCR foram testadas em diluições 1:5 do RNA total previamente tratado com DNAse I e variando as concentrações de $1,4 \mathrm{ng} \mu \mathrm{L}^{-1}$ até $3,6 \mathrm{fg}^{\mathrm{L}} \mathrm{L}^{-1}$. A amostra controle de RNA total foi extraída a partir de esporos de $A$. acidoterrestris na

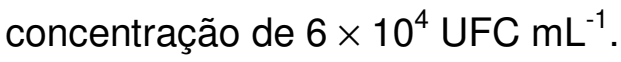

As reações de nested RT-PCR foram realizadas com os produtos de RT-PCR, e uma curva padrão foi obtida utilizando as concentrações produzidas pelos produtos de RT-PCR e nested RT-PCR.

Também foi realizada uma comparação entre os produtos das reações de RTPCR de $A$. acidoterrestris inoculados em meio de cultura e suco de laranja nas concentrações de $2 \times 10^{4}$ até $2 \mathrm{CFU} \mathrm{mL}{ }^{-1}$, para avaliar a influência produzida pela matriz do alimento nas reações. 


\subsubsection{Reação nested RT-PCR}

A segunda reação de nested RT-PCR foi realizada em volume final de $20 \mu \mathrm{L}$ contendo tampão de PCR $1 \times 1,5 \mathrm{mM} \mathrm{MgCl}, 0,2 \mathrm{mM}$ dNTPs, 1 U Taq-DNA polimerase (Invitrogen), $1 \mu \mathrm{M}$ de cada primer específico desenhado (NAtb-F e NAtbR) e $2 \mu \mathrm{L}$ do primeiro produto de RT-PCR como alvo. As condições térmicas foram às mesmas utilizadas na reação RT-PCR, usando a temperatura de pareamento de $56{ }^{\circ} \mathrm{C}$. Os produtos das reações nested RT-PCR foram analisados por eletroforese em gel de agarose $1,5 \%$ e depois por eletroforese capilar em microchips com detecção por fluorescência a laser no Bioanalyzer 2100 (Agilent Technologies) para sua quantificação.

\subsubsection{Detecção da viabilidade de $A$. acidoterrestris por RT-PCR}

O poder bactericida das saponinas em sucos de laranja foi estudado com o extrato metanólico da Sapindus saponaria. Uma amostra de suco de laranja contaminada com $1 \times 10^{4} \mathrm{UFC} / \mathrm{mL}$, foi inoculado com $1 \%$ do extrato metanólico de saponinas e logo incubadas à $45^{\circ} \mathrm{C}$ por 2 e 4 dias. Usando o mesmo procedimento de extração direta com o reagente Trizol; $1 \mathrm{~mL}$ de cada amostra retirada nos diferentes dias foi usada para a extração do RNA. As reações de RT-PCR foram realizadas seguindo o mesmo protocolo descrito anteriormente.

\subsubsection{Monitoração da viabilidade de $A$. acidoterrestris por reações nested RT- PCR}

As análises de viabilidade foram monitoradas com extratos purificados de Sapindus saponaria na concentração de $200 \mathrm{mg} \mathrm{L}^{-1}$ inoculados em sucos de laranja 
contendo $4 \times 10^{4}$ UFC $\mathrm{mL}^{-1}$ de $A$. acidoterrestris. As amostras inoculadas foram expostas nos seguintes tratamentos para monitorar o grau de inibição: I) incubação de $45^{\circ} \mathrm{C}$ por 2 dias, e ii) tratamento térmico de $99^{\circ} \mathrm{C}$ por $1 \mathrm{~h}$.

Foram realizadas as contagens de células viáveis para confirmar a não viabilidade das amostras inativadas nesses tratamentos. Alíquota de $100 \mu \mathrm{L}$ de cada amostra tratada foi analisada por plaqueamento por profundidade no meio agar-YGS $(\mathrm{pH} 3,7)$ e incubadas a $45^{\circ} \mathrm{C}$ por 5 dias.

Utilizando o procedimento direto de extração de RNA total, foi realizado o isolamento com o reagente Trizol a partir de $1 \mathrm{~mL}$ de cada amostra. As reações de RT-PCR e nested RT-PCR foram realizadas seguindo os mesmos protocolos descritos nas seções 2.3 .5 e 2.3.9, respectivamente.

\subsubsection{Eletroforese capilar em gel com detecção UV}

Um instrumento comercial Agilent HP3DCE com detecção UV constituído de um detector com arranjo de diodos (DAD) foi utilizado na separação eletroforética utilizando um capilar com revestimento interno de PVA (polivinilalcool) de $75 \mu \mathrm{m}$ de diâmetro interno e $39,5 \mathrm{~cm}$ de comprimento. A solução tampão de eletroforese utilizada foi de 100 mM NPe4-TAPS (100 mM de NPe4OH, 100 mM de TAPS, 2 mM EDTA, pH 8,3), contendo hidroxietilcelulose (1\% HEC, MM140-160 kDa) como meio de separação. A injeção eletrocinética foi utilizada para as alíquotas de DNA que foram injetadas por $10 \mathrm{~s}$ a $300 \mathrm{~V} \mathrm{~cm}^{-1}$, o campo elétrico aplicado foi de $300 \mathrm{~V} \mathrm{~cm}^{-1} \mathrm{a}$ $25{ }^{\circ} \mathrm{C}$. O padrão de DNA $\Phi \times 174 /$ Haelll $\left(1 \mathrm{mg} \mathrm{mL}^{-1}\right)$ constituído de 11 fragmentos variando de 72 a 1323 bp (CARUSO, 2003). 
Esta técnica foi utilizada para realizar as análises preliminares na quantificação dos produtos de PCR, obtidos a partir de sucos de laranja inoculados com $A$. acidoterrestris.

\subsubsection{Detecção dos produtos amplificados por eletroforese em microchips}

Para utilização do Bioanalyzer 2100 (Agilent Technologies, Alemanha) seguese detalhadamente o protocolo de manipulação de preparo do chip de separação em eletroforese em gel, introdução dos marcadores de tamanho, amostras e corantes. Aplica-se em cada reservatório indicado no chip, o gel de poliacrilamida com intercalador fluorescente $(9 \mu \mathrm{L})$, marcador de corrida $(5 \mu \mathrm{L})$ com cada amostra $(1 \mu \mathrm{L})$ e o padrão de tamanho de corrida de correspondente ao kit. O microchip foi colocado dentro do equipamento que contém um detector de fluorescência induzida a laser. O tempo de análise para 12 amostras foi de aproximadamente de 30 min entre preparação, aplicação de amostra, análise e coleta de dados.

Todos os experimentos foram realizados utilizando o kit DNA 500 LabChip $^{\circledR} \mathrm{e}$ DNA 1000 LabChip $^{\circledR}$, e analisados no software da Agilent Biosizing (Versão A. 02.12).

\subsection{RESULTADOS E DISCUSSÕES}

\subsubsection{Comparação de métodos eletroforéticos para a detecção das $\boldsymbol{A}$. Acidoterrestris.}

A avaliação do melhor método eletroforético foi realizada em produtos amplificados na PCR (294 bp) de cada amostra de DNA extraídas dos sucos 
inoculados com as A. acidoterrestris. A detecção do amplicon foi verificada por eletroforese em placa de gel de agarose e eletroforese capilar em gel.

2.4.1.1. Eletroforese em placa de gel de agarose com coloração por brometo de etídeo

Na Figura 2.3, observa-se claramente que foram amplificados o DNA de sucos inoculados até com $10 \mathrm{UFC} / \mathrm{mL}$. Nas concentrações abaixo de $10 \mathrm{UFC} / \mathrm{mL}$, i.e., 1 e $10^{-1} \mathrm{UFC} / \mathrm{mL}$, pode-se perceber a presença de leves traços de coloração. Como não temos disponível um densitômetro ou um analisador digital de imagens, a determinação inequívoca da menor concentração de UFC/mL dever ser mantida em valores elevados.

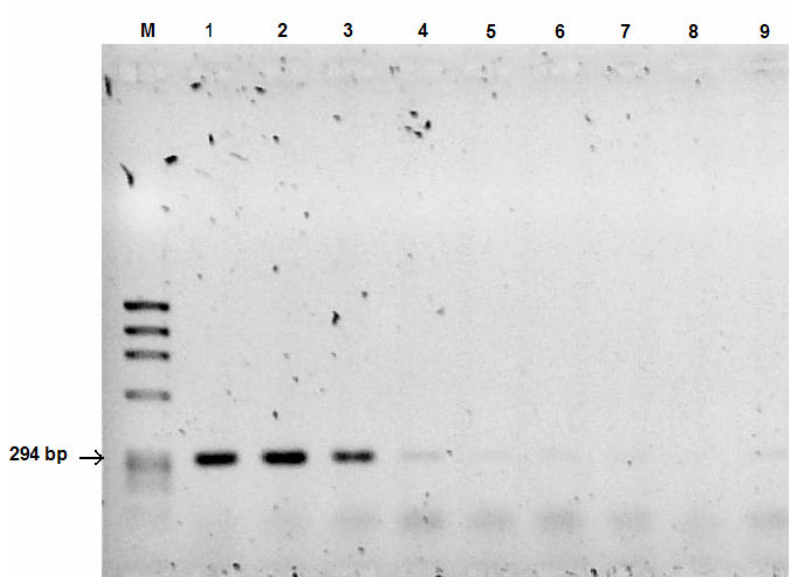

Figura 2.3: Determinação do número mínimo de UFC/mL para deteç̧ão positiva de A. acidoterrestris por PCR. Identificação das canaletas: marcador de tamanho de DNA phiX174/Hae III (M), $10^{3} \mathrm{UFC} / \mathrm{mL}$ (1), $10^{2} \mathrm{UFC} / \mathrm{mL}$ (2), $10 \mathrm{UFC} / \mathrm{mL}$ (3), 1 $\mathrm{UFC} / \mathrm{mL}$ (4), $10^{-1} \mathrm{UFC} / \mathrm{mL}$ (5), $10^{-2} \mathrm{UFC} / \mathrm{mL}$ (6), $10^{-3} \mathrm{UFC} / \mathrm{mL}$ (7), $10^{-4} \mathrm{UFC} / \mathrm{mL}$ (8), $10^{-5} \mathrm{UFC} / \mathrm{mL}$ e controle negativo (9). 


\subsubsection{Eletroforese capilar com soluções poliméricas}

Na Eletroforese Capilar (Figura 2.4) com detecção UV, no comprimento de onda de $260 \mathrm{~nm}$, observa-se claramente que foram amplificados os DNA de sucos inoculados até com $10 \mathrm{UFC} / \mathrm{mL}$, tanto no gel quanto no eletroforese capilar. Nas concentrações abaixo de $10 \mathrm{UFC} / \mathrm{mL}, 1$ e $10^{-1} \mathrm{UFC} / \mathrm{mL}$, pode-se perceber a presença de leves traços de coloração e ruído, respectivamente. Porém, a determinação inequívoca da menor concentração em UFC/mL deve ser mantida em valores elevados.
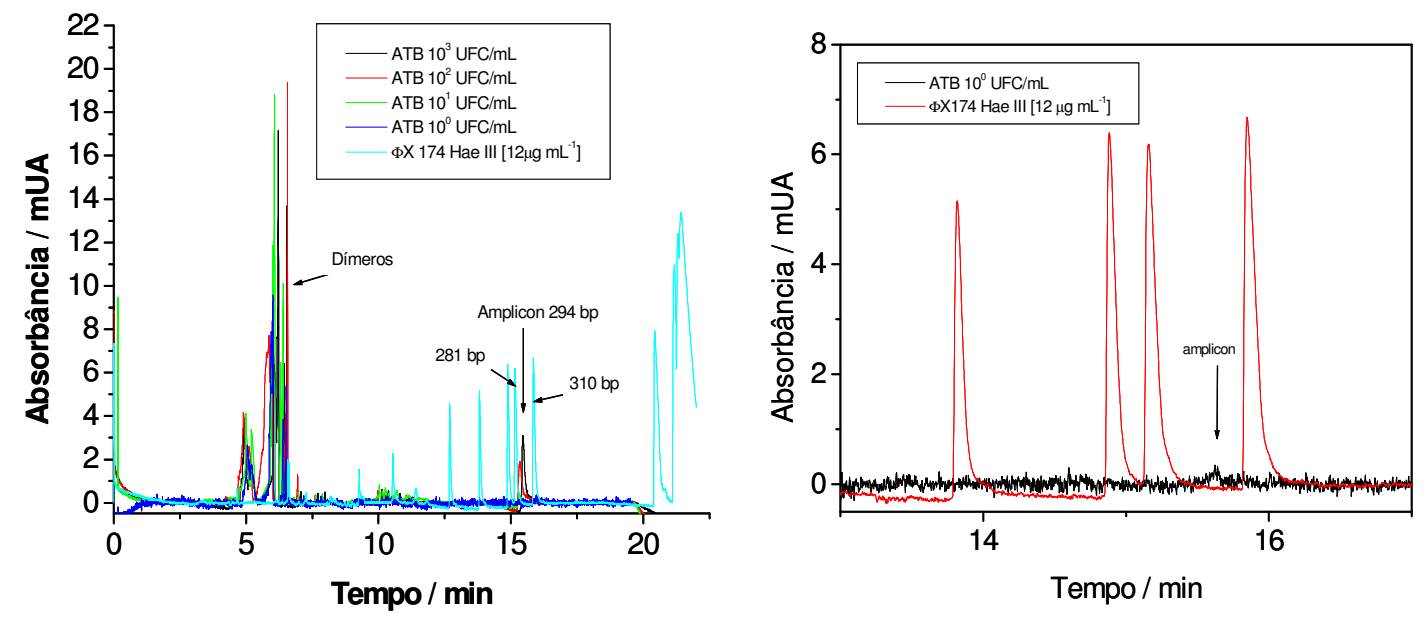

Figura 2.4: Eletroferograma de eletroforese capilar em gel com detecção espectrofotométrica em $260 \mathrm{~nm}$ para amostras de PCR em diferentes graus de inoculação em sucos de laranja com $A$. acidoterrestris (ATB).

2.4.1.3. Eletroforese capilar em microchip com detecção por florescência a laser (LIF)

As mesmas amostras de produtos de PCR foram analisadas por eletroforese capilar em gel com a detecção de florescência induzida a laser no equipamento Bioanalyzer 2100 e os resultados são mostrados na Figura 2.5. As corridas 
realizaram-se em menos de 2 min por cada amostra, utilizando como padrão de corrida um marcador de tamanho de $1000 \mathrm{bp}$ fornecido pelo mesmo fabricante do equipamento. Este método de separação e detecção resultou-se mais sensível permitindo-se detectar claramente até $10^{-3} \mathrm{UFC} / \mathrm{mL}$ de $A$. acidoterrestris em suco de laranja, como pode ser confirmado na Figura 2.5.

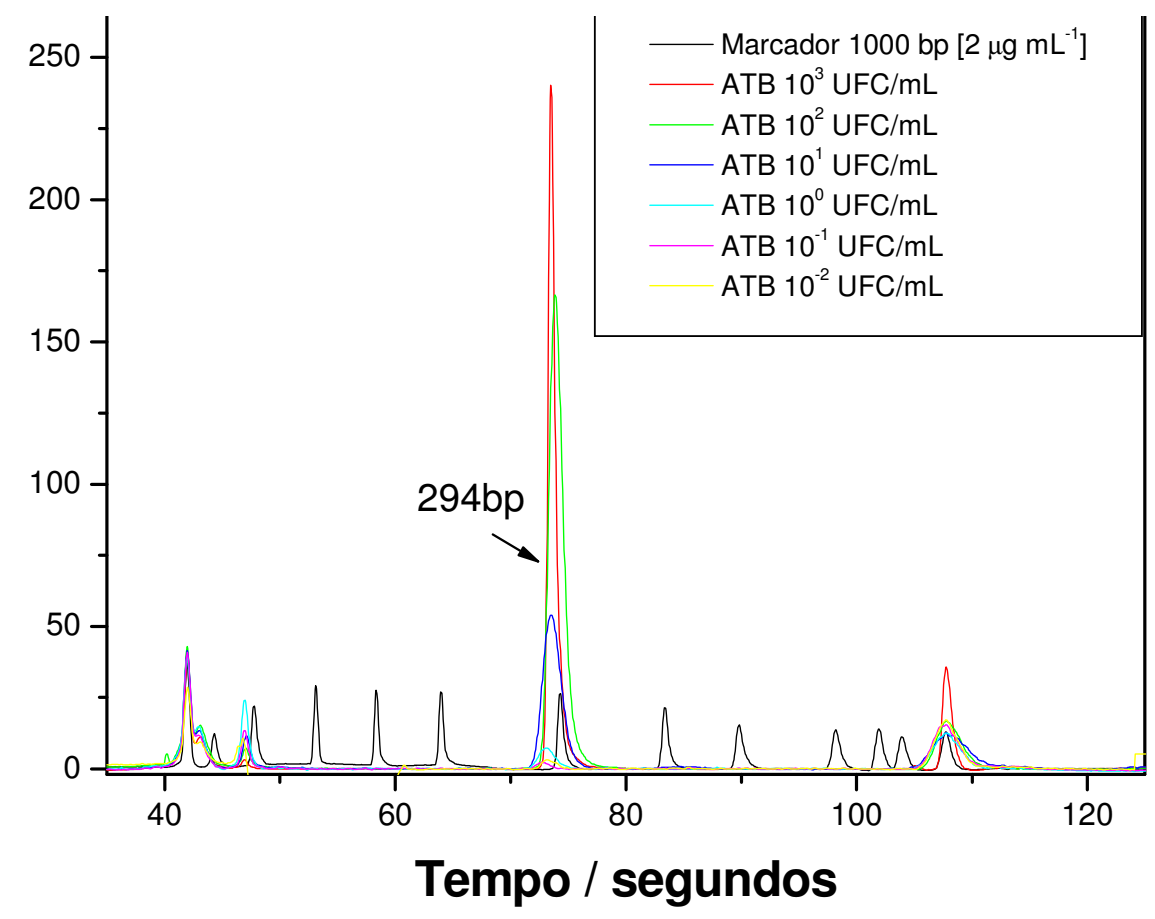

Figura 2.5: Eletroferograma com detector LIF para amostras de PCR a diferente grau de inoculação em sucos de laranja das $A$. acidoterrestris (ATB) em plataforma microfluidica.

\subsubsection{Quantificação de A. acidoterrestris por RT-PCR em microchips}

Os amplicons de produtos de PCR e RT-PCR foram analisados por eletroforese capilar em gel com detecção de fluorescência induzida a laser no equipamento Bioanalyzer 2100 (Agilent Technologies). Este método de detecção, também realiza a quantificação e medição automatizada de cada amplicon, sendo calculada a concentração em ng/ $\mu \mathrm{L}$. 
Os produtos mostraram um aumento quantitativo na concentração da banda do amplicon específico de acordo com o número de células viáveis e tempos de incubação. As análises foram mais sensíveis após o enriquecimento por 12 h à 45 ${ }^{\circ} \mathrm{C}$ de incubação, no entanto, com uma linearidade menor $(r=0,969)$ do que a $0 \mathrm{~h}(\mathrm{r}$ $=0,985)$. Na Figura 2.6, estão representadas as curvas de $0 \mathrm{~h}$, claramente linear, enquanto que a curva de $12 \mathrm{~h}$ apresenta uma forma sigmoidal. Isto é devido à formação de endoesporos de $A$. acidoterrestris nas diluições de $2 \times 10^{1}$ a 2 UFC/mL, apresentando uma diminuição na síntese de RNA. Quando a bactéria está na forma de endoesporos seu metabolismo é lento (síntese de RNA e proteínas) e isto é marcado através da baixa concentração de RNA extraído nas menores diluições realizadas.

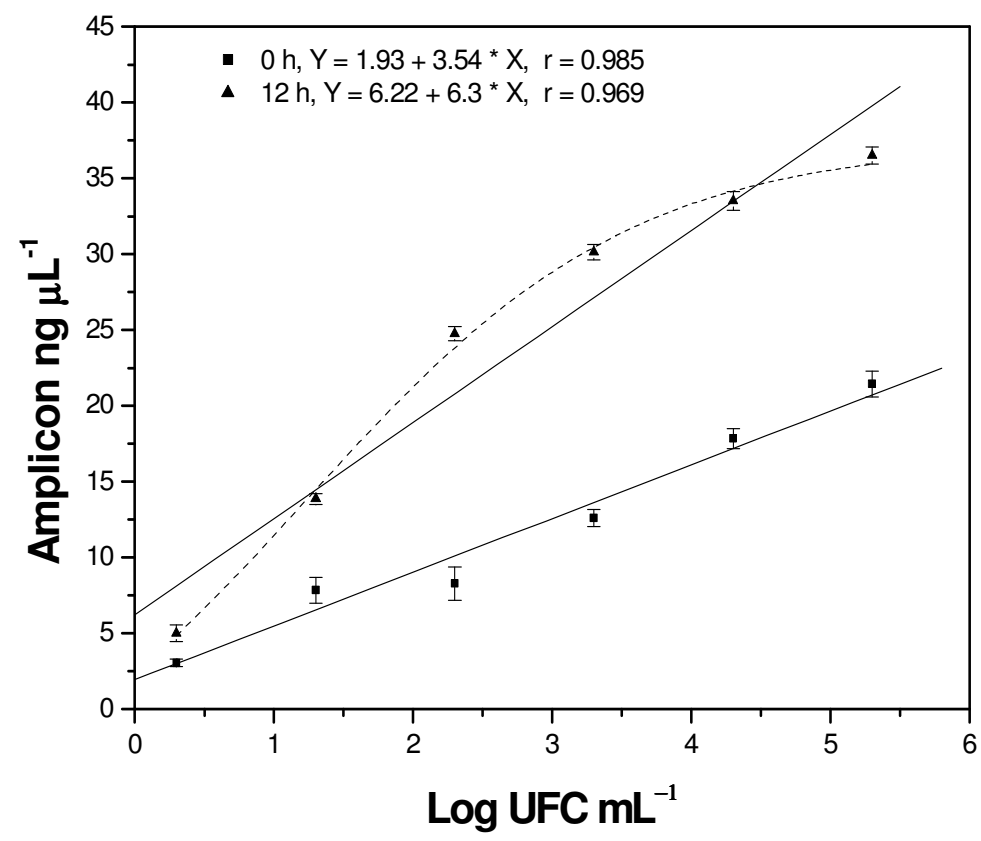

Figura 2.6: Variação de concentração de amplicons de RT-PCR de produtos do gene de $A$. acidoterrestris. Concentração de amplicons de RT-PCR suspendidos em médio de $2 \times 10^{5}-2$ UFC/mL depois de 0 e $12 \mathrm{~h}$ de incubação. 
A diferença é maior em valores elevados de UFC/mL, mas isto não oferece vantagem particular, sendo que a concentração para $0 \mathrm{~h}$ é suficientemente alta para permitir a medida da concentração precisa. De qualquer forma, a curva levantada a $12 \mathrm{~h}$ de crescimento foi tratada como linear para efeitos de comparação.

A comparação de produtos de RT-PCR de $A$. acidoterrestris inoculados $(2 \times$ $10^{4}$ até 2 UFC $\mathrm{mL}^{-1}$ ) em meio de cultura e em suco de laranja foram obtidos no gráfico de concentração de amplicons contra a concentração de células em UFC mL 1. Estas análises indicaram que foi possível detectar $A$. acidoterrestris em concentrações até de 2 UFC $\mathrm{mL}^{-1}$ em meio de cultura pura e suco de laranja. $\mathrm{Na}$ Figura 2.7, observamos que a concentração dos amplicons obtidos de sucos inoculados foram proporcionalmente menores, isto pode ser atribuído às substâncias presentes na matriz do suco de laranja que inibiram as enzimas transcriptase reversa e DNA polimerase nas duas reações de amplificação, respectivamente. No entanto, o grau de inibição é amplamente dependente do tipo de alimento a ser analisado.

Embora as diferenças na amplificação, os valores de regressão linear de culturas puras e de sucos de laranja foram 0,993 e 0,994 , respectivamente. Considerando a grande diferença em ambos meios, a correlação pode ser considerada aceitável nos dois casos, indicando a confiabilidade do método. 


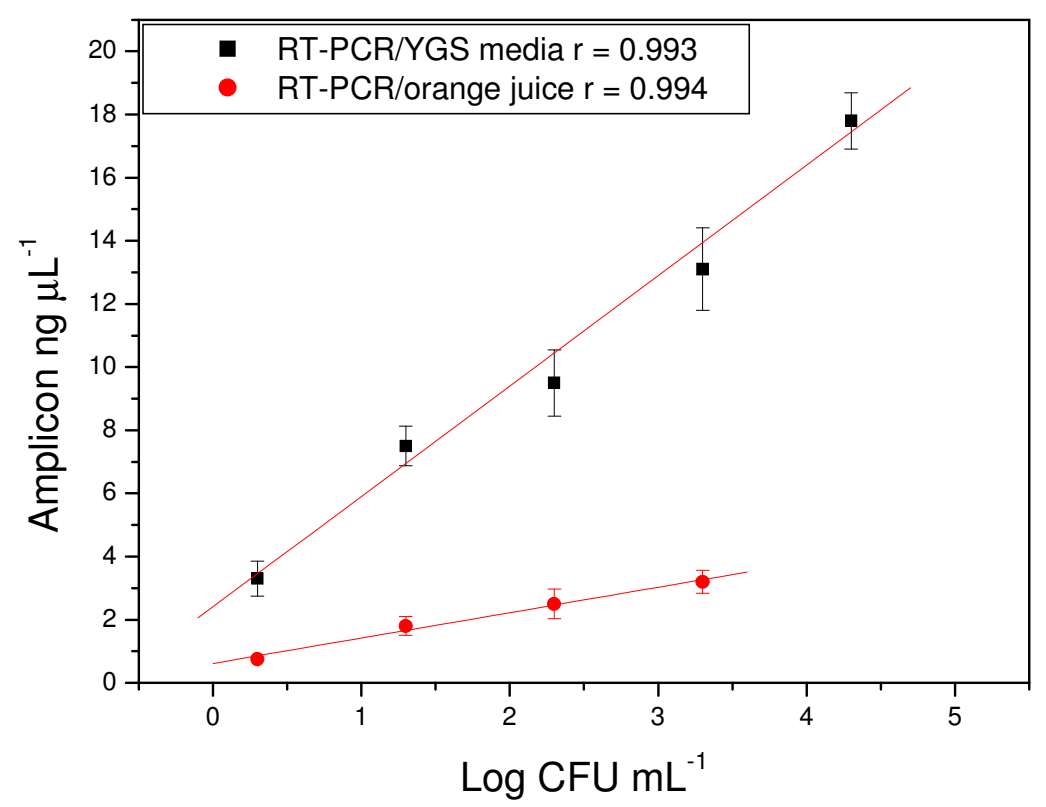

Figura 2.7: Comparação entre produtos de RT-PCR detectados no meio YGS e sucos de laranja inoculado com $A$. acidoterrestris, nas concentrações de $2 \times 10^{4}$ até 2 UFC $\mathrm{mL}^{-1}$.

\subsubsection{Comparação entre PCR e RT-PCR}

A comparação entre dois métodos de amplificação foi realizada com a mesma quantidade de amostra para cada ensaio e com variação do enriquecimento de 0 a 12 h. A PCR apresentou uma concentração do produto amplificado para meios com $2 \times 10^{5} \mathrm{UFC} / \mathrm{mL}$ de $25,3 \mathrm{ng} / \mu \mathrm{L}$ em comparação com $21,4 \mathrm{ng} / \mu \mathrm{L}$ para RT-PCR (Figura 2.8). A maior concentração apresentada foi devido à enzima Taq-DNA polimerase atuar indistintamente em DNAs de células de bactérias viáveis e não viáveis. Ao contrário da PCR, a técnica de RT-PCR esta diretamente relacionada com a viabilidade das células. 

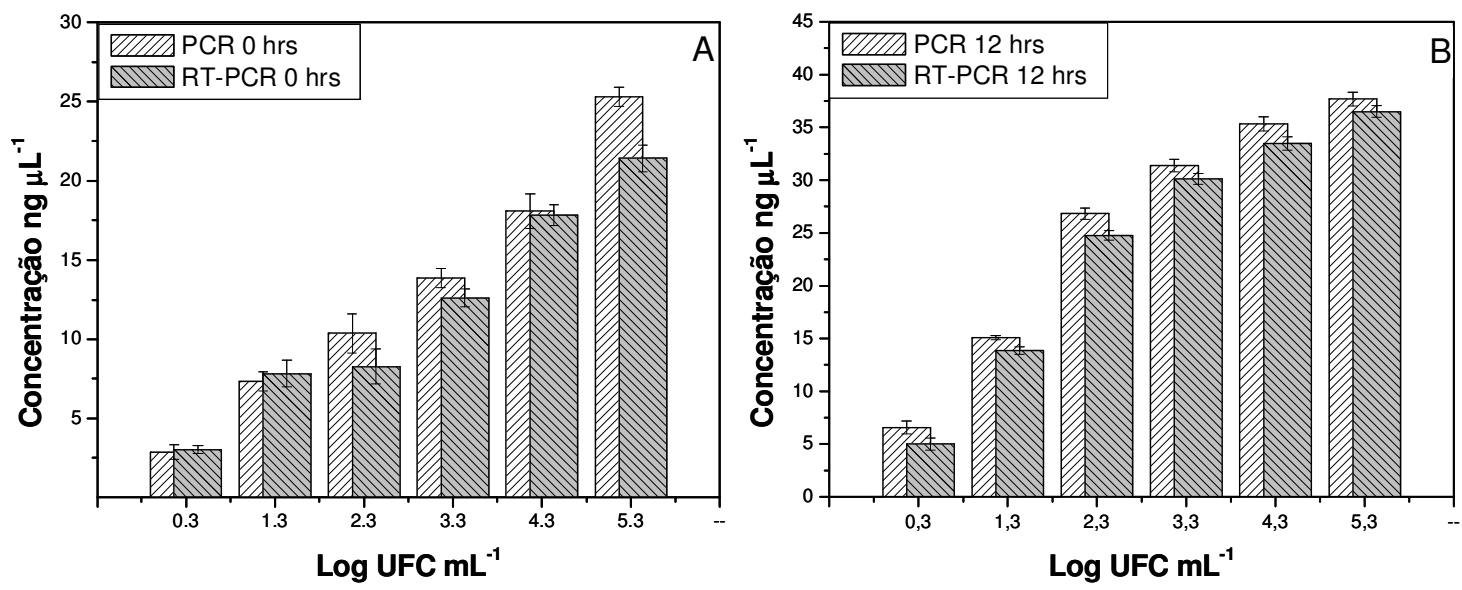

Figura 2.8: Comparação entre quantidade amplicons de PCR e RT-PCR das $A$. acidoterrestris em diluições de $2 \times 10^{5}-2 \mathrm{UFC} / \mathrm{mL}$, para $0 \mathrm{~h}(\mathrm{~A})$ e $12 \mathrm{~h}$ de incubação. Testes realizados no Bionalyzer 2100 (Agilent Technologies).

\subsubsection{Viabilidade e Inibição de A. acidoterrestris em sucos de laranja por RT- PCR.}

Usando a RT-PCR, o controle da contaminação em bebidas ácidas pode ser realizado em menos de $24 \mathrm{~h}$, com limites de detecção de 1 UFC/mL. Estes ensaios acelerados, melhoram e simplificam a rotina microbiológica. Os dados apresentados na Tabela 2.3, mostram que diferenças na concentração de amplicons podem ser observadas entre os produtos de RT-PCR de culturas puras e células inoculadas em sucos de laranja (Figura 2.9), devido à inibição dos componentes da matriz do alimento. Alguns componentes residuais dos alimentos podem inibir as reações enzimáticas; tais como as usadas em PCR. Geralmente, quando se incrementa a complexidade da matriz, a eficiência da extração dos ácidos nucléicos diminui (McKILLIP, 2000). 


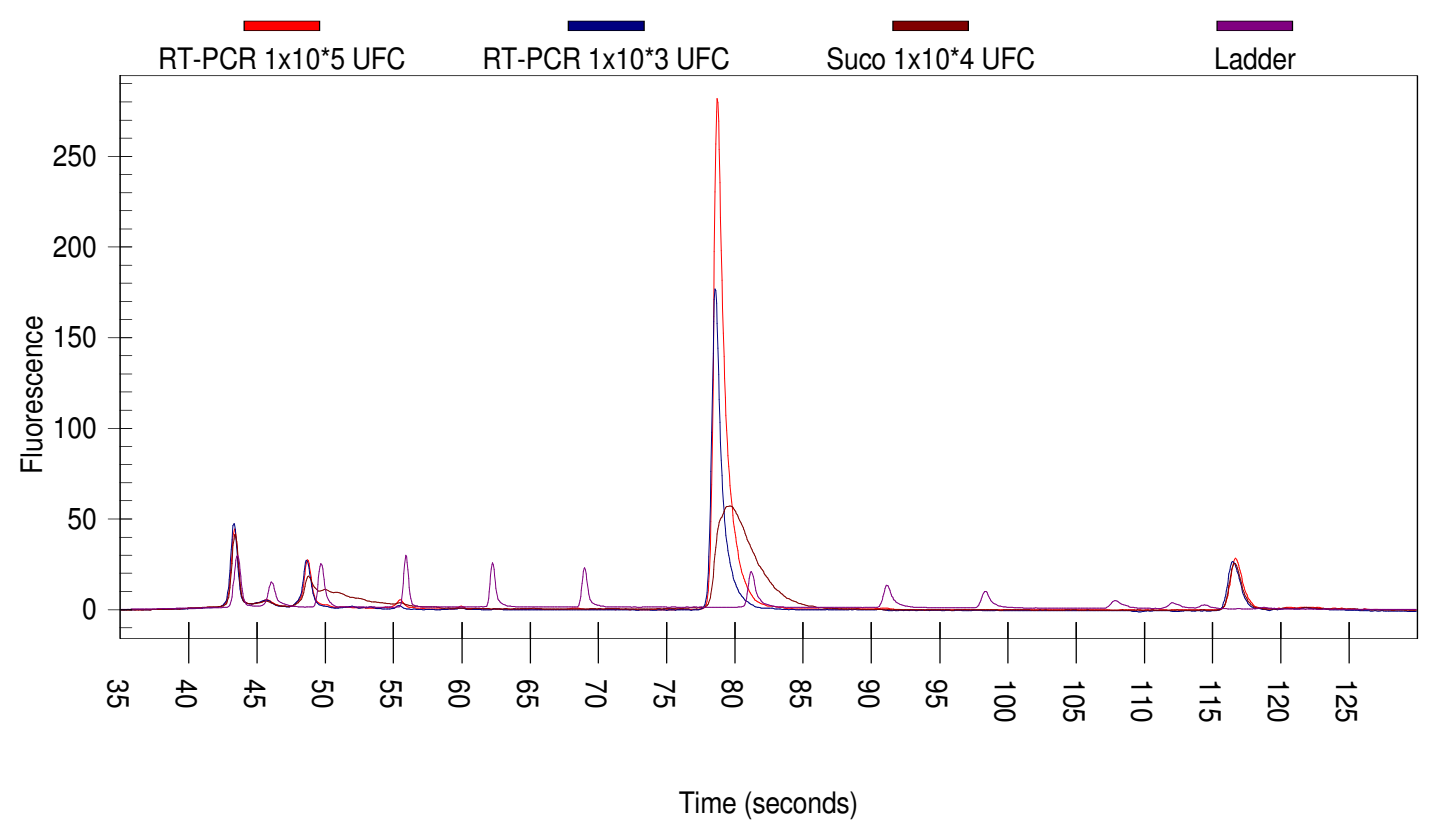

Figura 2.9: Comparação de amplicons de RT-PCR (294 bp) em amostras de culturas puras e sucos de laranja inoculados com A.acidoterrestris.

A variação entre a concentração de produtos de RT-PCR e células viáveis em sucos de laranja tratadas com inibidor foi verificada na incubação das células com extrato metanólico a $1 \%$ do fruto da S. saponaria, para zero, dois e quatro dias de incubação à $45^{\circ} \mathrm{C}$ (Tabela 2.3). Uma diminuição significativa no número de células foi observada depois de dois dias de incubação. 
Tabela 2.3: Dados quantitativos de produtos de RT-PCR das $A$. acidoterrestris em sucos de laranja inoculados com e sem inibidor natural do extrato metanólico dos frutos da S. saponaria.

\begin{tabular}{l|c|c}
\hline \hline \multicolumn{1}{c|}{$\begin{array}{l}\text { Amostra } \\
(\mathrm{UFC} / \mathrm{mL})\end{array}$} & $\begin{array}{c}\text { Concentração } \\
\text { do amplicon } \\
(\mathrm{ng} / \mathrm{\mu L})\end{array}$ & $\begin{array}{c}\text { Intensidade de } \\
\text { fluorescência } \\
(\mathrm{URF})\end{array}$ \\
\hline \hline RT-PCR cultura pura, $2 \times 10^{5}$ & 21.4 & 283.0 \\
RT-PCR cultura pura, $2 \times 10^{4}$ & 17.8 & 177.0 \\
RT-PCR suco de laranja, $1 \times 10^{4}$ & 3.6 & 50.8 \\
RT-PCR suco de laranja, $1 \times 10^{3}$ & 1.7 & 18.9 \\
RT-PCR suco de laranja, $1 \times 10^{2}$ & 0.8 & 8.3 \\
RT-PCR suco de laranja, $1 \times 10^{1}$ & 0.7 & 3.4 \\
RT-PCR suco de laranja, $1 \times 10^{4} /$ & 0.3 & 2.6 \\
inibidor 2d. & & \\
RT-PCR suco de laranja, $1 \times 10^{4} /$ & 0.1 & 1.6 \\
inibidor 4d. & & \\
Controle negativo RT-PCR & $\mathrm{ND}$ & $\mathrm{ND}$ \\
\hline \hline
\end{tabular}

ND: Não detectado URF: Unidade Relativa de Fluorescência.

O suco de laranja inoculado com $1 \times 10^{4} \mathrm{UFC} / \mathrm{mL}$, mostrou uma diminuição de 90\% no segundo dia de incubação, indicando que o método de RT-PCR realizado neste estudo está bem fundamentado, principalmente para detectar células viáveis. As análises realizadas por eletroforese em microchips, mostraram uma diminuição na viabilidade de células depois do quarto dia de incubação (Figura 2.10). 


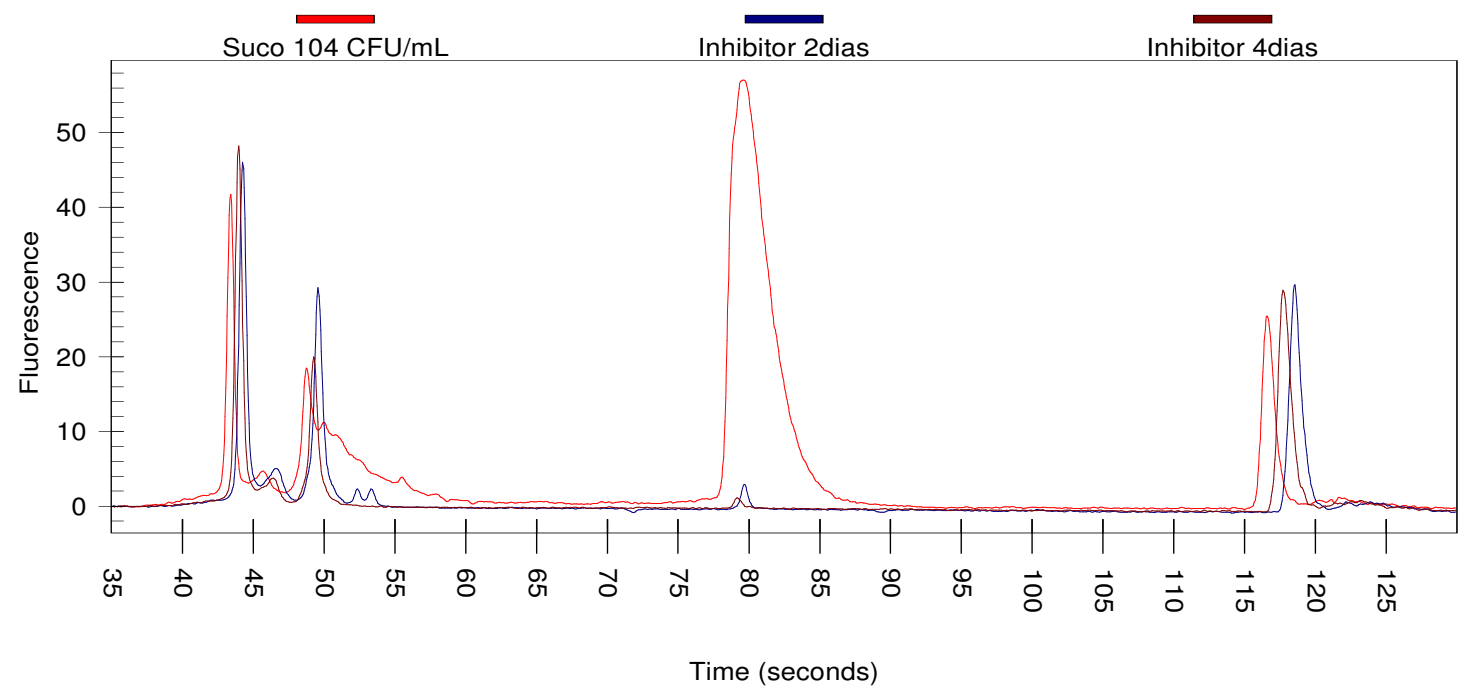

Figura 2.10: Eletroferograma de $1 \times 10^{4} \mathrm{UFC} / \mathrm{mL}$ em sucos de laranja e depois do tratamento com inibidor por dois e quatro dias.

\subsubsection{Desenho dos primers nested para reações nested RT-PCR}

Os primers NAtb-F e NAtb-R foram desenhados a partir da seqüência obtida pelo primeiro amplicon (294 bp) correspondente ao gene $16 \mathrm{~S}$ rRNA de $A$. acidoterrestris. Os primers desenhados amplificaram fragmentos internos de $191 \mathrm{bp}$, correspondentes a $A$. acidoterrestris. Na Figura 2.11, observamos o alinhamento gerado no programa GeneRunner (Versão 3.05), onde a seqüência do primeiro amplicon (294 bp) indica a região interna onde os primers NAtb-F e NAtb-R estão sendo hibridizados.

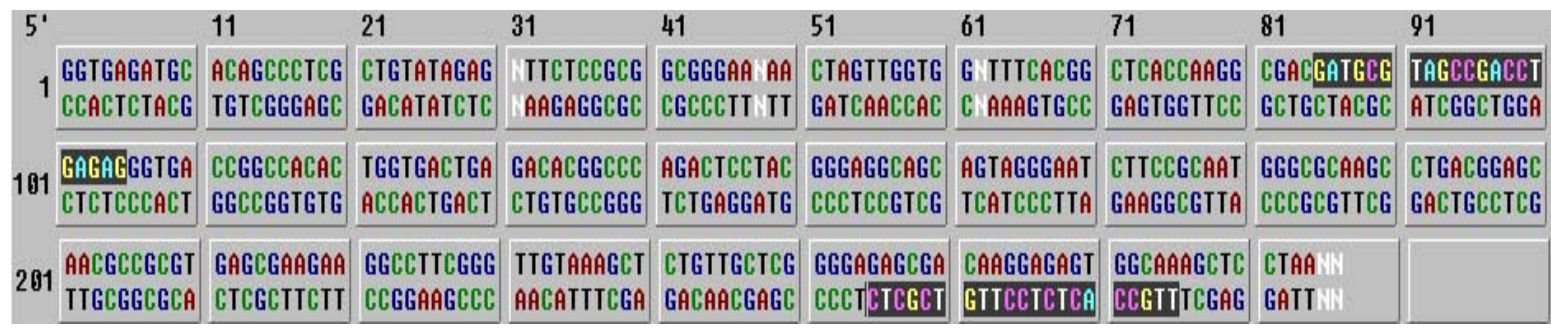

Figura 2.11: Seqüência do amplicon de 294 bp de $A$. acidoterrestris mostrando o pareamento dos primers NAtb-F e NAtb-R. 
Para avaliar a especificidade, primeiro foram realizadas as reações RT-PCR e posteriormente as nested RT-PCR, utilizando os controles: $A$. acidoterrestris, $A$. acidocaldarius e A. cycloheptanicus. Nas reações RT-PCR somente amplificou o controle de A. acidoterrestris (294 bp), comprovando a especificidade dos primeiros primers. No entanto, nas reações nested RT-PCR apresentaram amplificações positivas para os três controles. Em conseqüência a estes resultados, foram realizados reações de seqüenciamento, com os amplicons de 294 bp e 191 bp, para analisar a seqüências de cada controle.

Após o alinhamento das seqüências obtidas, pudemos identificar que os controles $A$. acidocaldarius e $A$. cycloheptanicus estiveram amplificando em regiões internas conservadas do $A$. acidoterrestris, devido a que todas as seqüências tiveram porcentagens de identidade entre 99 e $100 \%$ com respeito a $A$. acidoterrestris. Nos três casos, as seqüências pertencem ao 16S rRNA de Alicyclobacillus acidoterrestris, com número de acesso AY573797. O que indica que estes primers somente seriam específicos para avaliar a sensibilidade na detecção de $A$. acidoterrestris.

\subsubsection{Avaliação do limite de detecção em reações nested RT-PCR}

O limite de deteçcão nas reações RT-PCR e nested RT-PCR foram testadas em diluições seriadas 1:5 de RNA total que variaram entre $1,4{\mathrm{ng} \mu \mathrm{L}^{-1}}$ até $3,6 \mathrm{fg} \mu \mathrm{L}^{-1}$, obtido a partir de uma cultura $A$. acidoterrestris com $6 \times 10^{4} \mathrm{UFC} \mathrm{mL}^{-1}$. Por tanto, as diluições seriadas do RNA total corresponderam a concentrações de $6 \times 10^{4}$ até 0,1 UFC $\mathrm{mL}^{-1}$.

Os eletroferogramas de produtos de nested RT-PCR (191 bp) apresentados na Figura 2.12, indicaram que o limite de detecção foi de 3,6 fg de RNA, equivalente 
0,1 UFC $\mathrm{mL}^{-1}$. Estes resultados, demonstraram uma boa correlação linear entre os produtos amplificados de cada diluição e o sinal de fluorescência obtido na eletroforese capilar em microchips. Uma comparação desta linearidade é apresentada na Figura 2.13, onde as primeiras reações de RT-PCR tiveram um valor de coeficiente de regressão $(r=0.995)$, levemente maior do obtido na curva de calibração de produtos nested RT-PCR $(r=0.966)$.

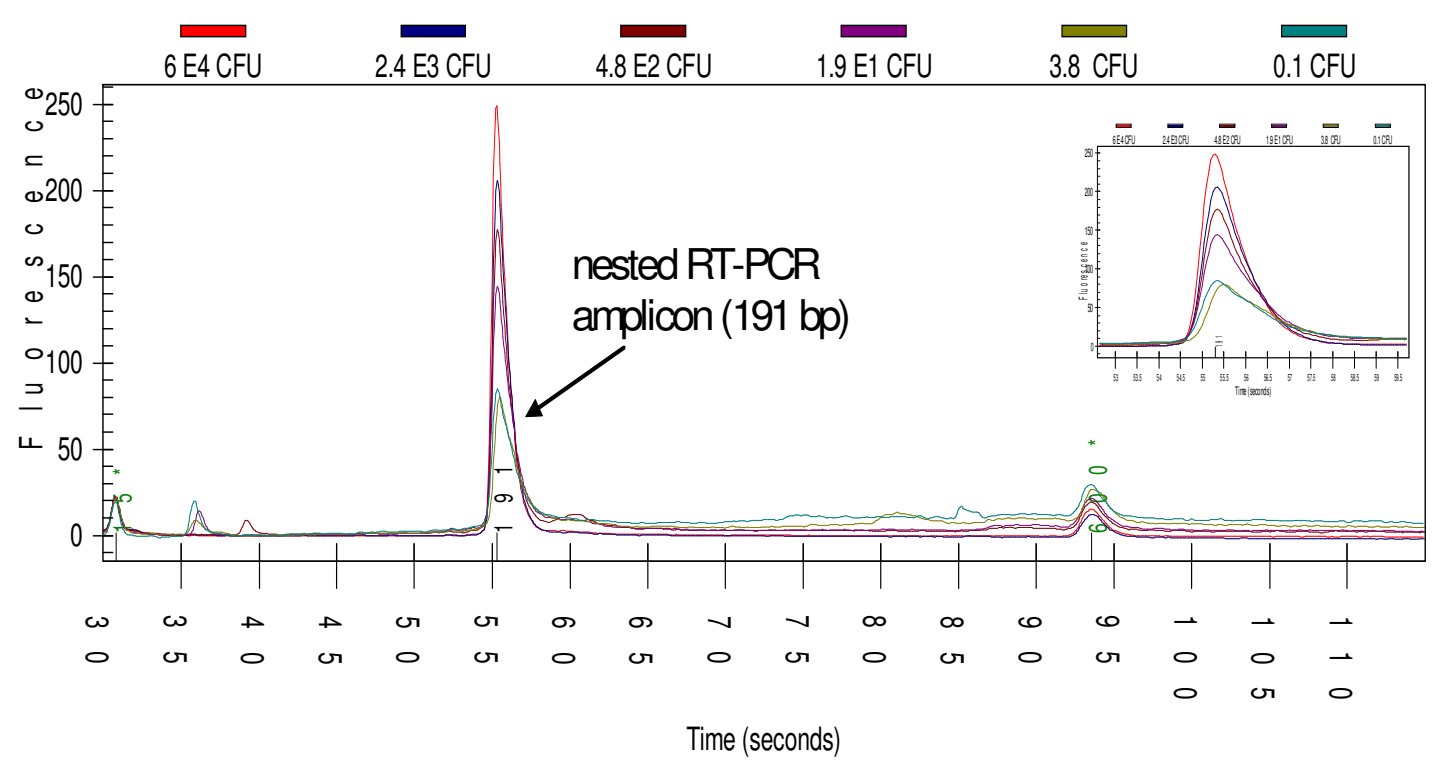

Figura 2.12: Eletroforese em microchips de produtos nested RT-PCR. Limite de detecção de nested RT-PCR de $A$. acidoterrestris inoculados com $6 \times 10^{4}$ até 0,1 UFC ml${ }^{-1}$, usando o Bioanalyzer 2100 (Agilent Technologies). 


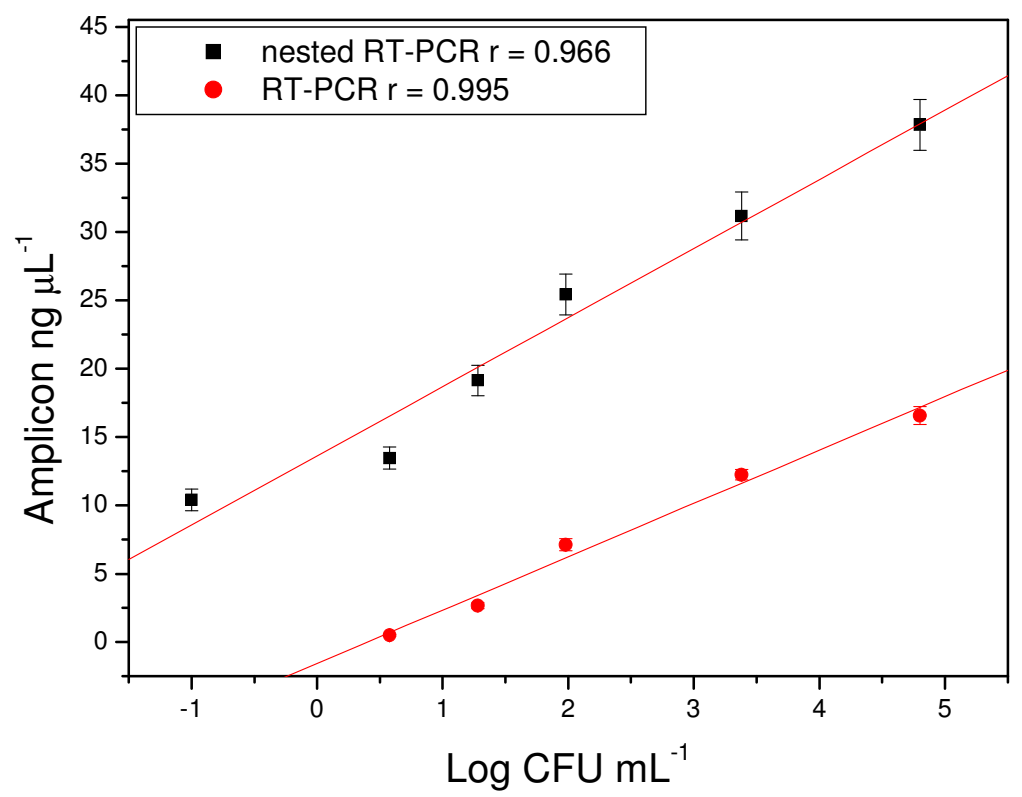

Figura 2.13: Comparação entre produtos de RT-PCR e nested RT-PCR detectados a partir de $A$. acidoterrestris inoculados no meio $Y G S$, a concentrações de $6 \times 10^{4}$ até 0,1 UFC $\mathrm{mL}^{-1}$. Dados quantitativos foram obtidos usando o Bioanalyzer 2100 (Agilent Technologies).

\subsubsection{Monitoração da viabilidade de A. acidoterrestris sob tratamento térmico e inibição com saponinas utilizando nested RT-PCR.}

A incubação de $A$. acidoterrestris em sucos de laranja com frações purificadas de S. saponaria, indicou a relação entre a detecção de RNA por nested RT-PCR e a viabilidade das $A$. acidoterrestris. $\mathrm{O}$ efeito de inibição térmica, a $99{ }^{\circ} \mathrm{C}$ por $1 \mathrm{~h}$, no crescimento das bactérias inoculadas em suco de laranja $\left(4 \times 10^{4} \mathrm{UFC} \mathrm{mL}^{-1}\right)$ foi de $96,3 \%$, diminuindo sua concentração de $12,1 \mathrm{ng} \mathrm{LL}^{-1}$ até $0,44 \mathrm{ng}^{\mathrm{L}} \mathrm{L}^{-1}$. No entanto, utilizando as reações nested RT-PCR, a sensibilidade foi incrementada em

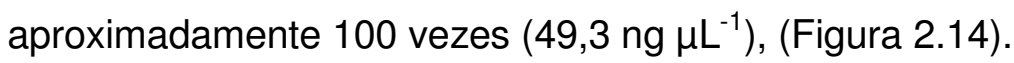




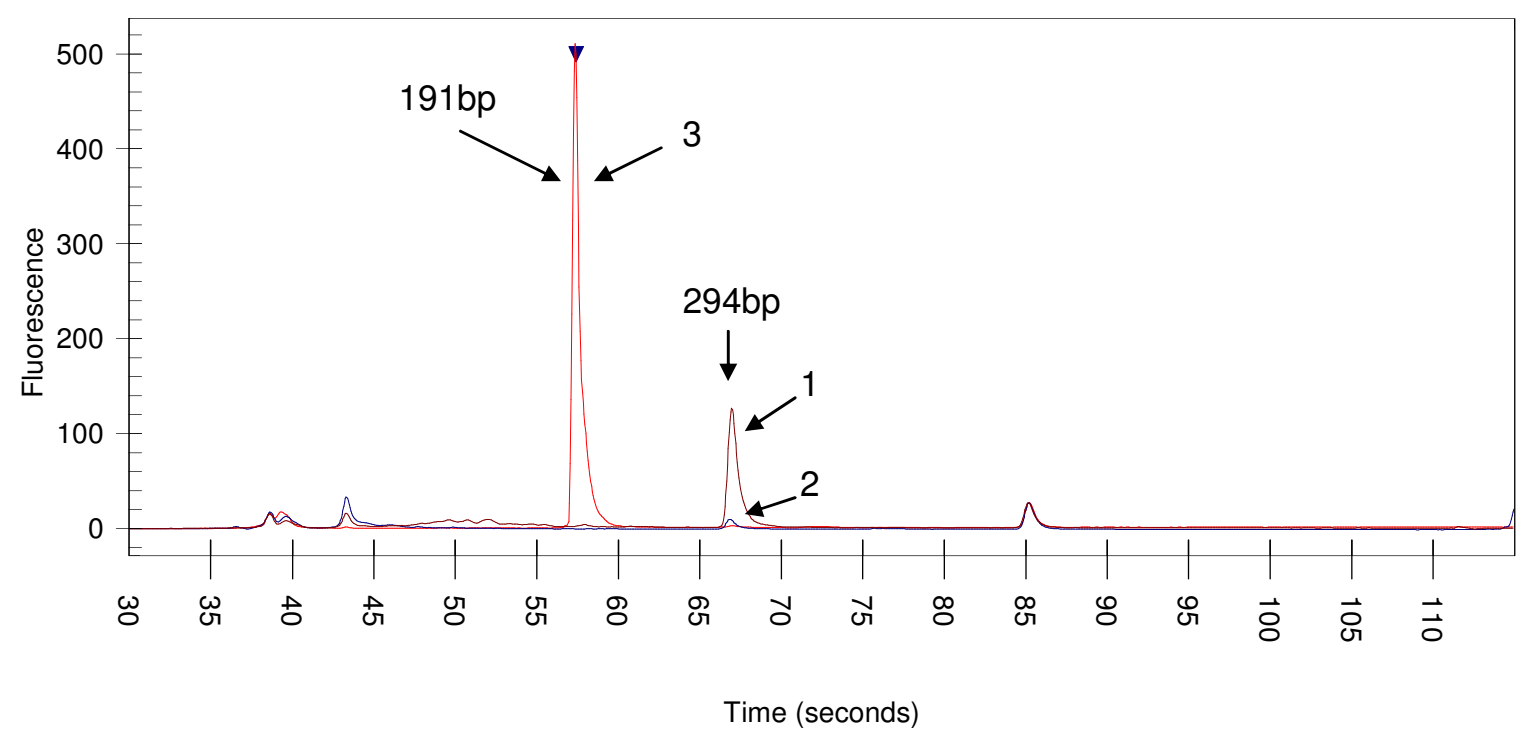

Figura 2.14: Eletroforese em microchips de RT-PCR (294 bp) e nested RT-PCR (191 bp) de $A$. acidoterrestris inoculados com $4 \times 10^{4}$ UFC $\mathrm{mL}^{-1}$ em suco de laranja. Comparação da viabilidade com tratamento de temperatura: (1) RT-PCR, suco de laranja, (2) RT-PCR, suco de laranja tratado a $99^{\circ} \mathrm{C} / 1 \mathrm{~h}$, (3) nested RT-PCR, suco de laranja tratado a $99^{\circ} \mathrm{C} / 1 \mathrm{~h}$.

Adicionalmente, o uso de uma fração purificada de Sapindus saponaria (200 $\mathrm{mg} \mathrm{L}^{-1}$ ) a diferentes temperaturas de incubação contribuiu na redução das bactérias viáveis. A incubação com $S$. saponaria à $45^{\circ} \mathrm{C} / 2 \mathrm{~d}$, condição típica para crescimento de $A$. acidoterrestris, inibiu o crescimento em $93,6 \%$, enquanto que com incubação a $99{ }^{\circ} \mathrm{C} / 1 \mathrm{~h}$ reduziu em $98,7 \%$ nas mesmas concentrações de saponinas. Estes resultados demonstraram que mesmo na temperatura regular de crescimento, as saponinas inibiram às $A$. acidoterrestris (Figura 2.15) e a inibição foi incrementada com o aumento da temperatura de incubação. 


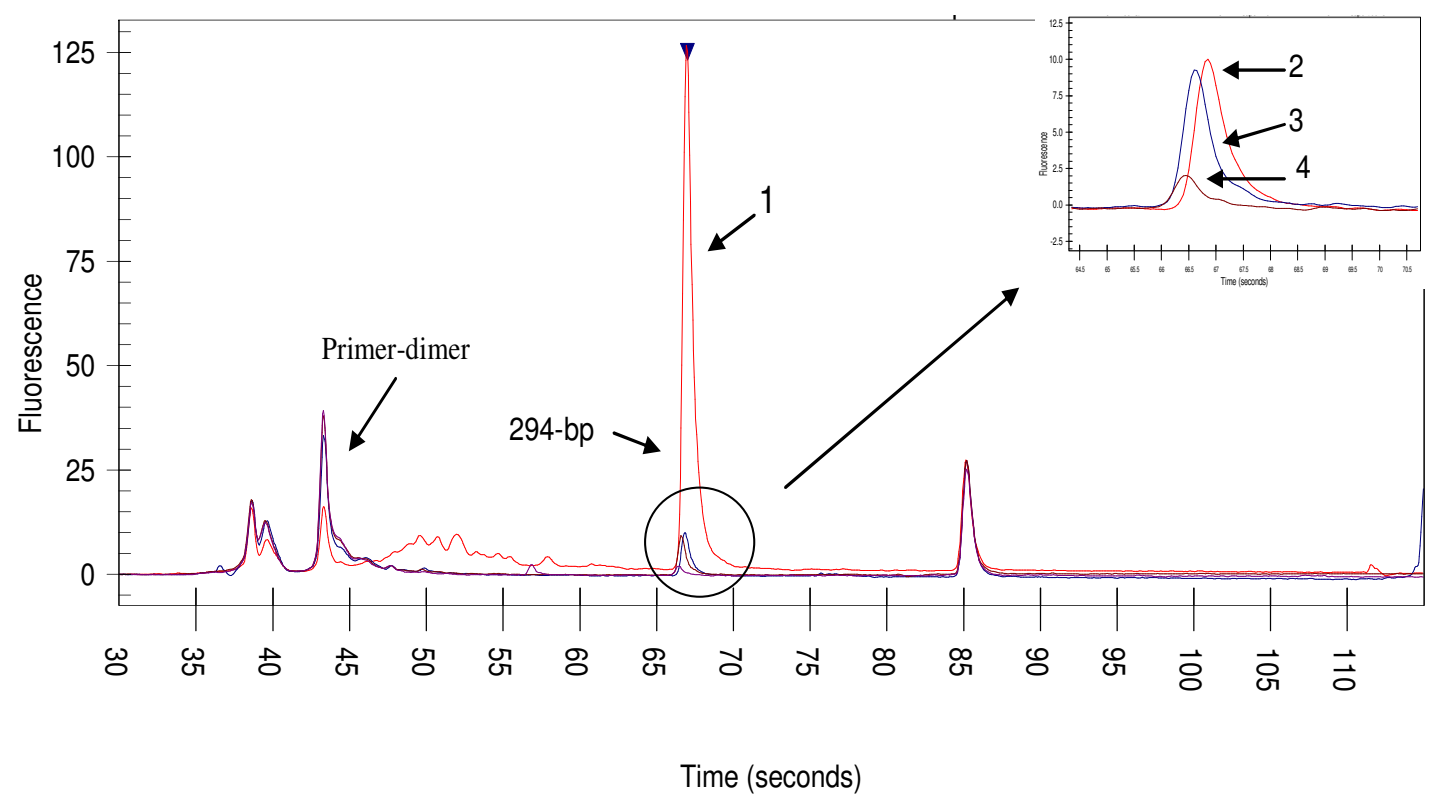

Figura 2.15: Eletroforese em microchips de RT-PCR (294-bp) de A. acidoterrestris inoculados com $4 \times 10^{4}$ UFC mL $\mathrm{mL}^{-1}$ em suco de laranja. Monitoração da viabilidade: (1) suco de laranja, (2) suco de laranja tratado a $99^{\circ} \mathrm{C} / 1 \mathrm{~h}$, (3) suco de laranja com S. saponaria $\left(200 \mathrm{mg} \mathrm{L}^{-1}\right)$, tratado a $45^{\circ} \mathrm{C} / 2 \mathrm{~d}$ (4) suco de laranja com S. saponaria $\left(200 \mathrm{mg} \mathrm{L}^{-1}\right)$, tratado a $99^{\circ} \mathrm{C} / 1 \mathrm{~h}$.

$\mathrm{Na}$ Tabela 2.4, mostramos claramente diferenças na concentração dos amplicons, referindo-se a diferentes números de células viáveis em cada tratamento. A comparação de dados quantitativos entre produtos de RT-PCR e nested RT-PCR de $A$. acidoterrestris incubados com frações purificadas de $S$. saponaria e tratadas a $99{ }^{\circ} \mathrm{C} / 1 \mathrm{~h}$, mostraram que a concentração dos produtos incrementaram em 200 vezes, de $0,13 \mathrm{ng} \mu \mathrm{L}^{-1}$ até $35,3 \mathrm{ng} \mu \mathrm{L}^{-1}$, respectivamente. 
Tabela 2.4: Dados quantitativos de RT-PCR e nested RT-PCR de produtos de $A$. acidoterrestris, em sucos de laranja inoculado com fração purificada de inibidor (Sapindus saponaria) e tratamentos à $99^{\circ} \mathrm{C}$.

\begin{tabular}{|c|c|c|}
\hline $\begin{array}{l}\text { Amostra } \\
\text { (UFC/mL) }\end{array}$ & $\begin{array}{l}\text { Concentração } \\
\text { do amplicon } \\
(\mathrm{ng} / \mu \mathrm{L})\end{array}$ & $\begin{array}{l}\text { Instensidade de } \\
\text { Fluorescência } \\
\text { (URF) }\end{array}$ \\
\hline RT-PCR cultura pura, $8 \times 10^{4}$ & $35,2^{*}$ & 380,7 \\
\hline $\begin{array}{l}\text { RT-PCR cultura pura, } 8 \times 10^{4} / \\
\text { inibidor } 99^{\circ} \mathrm{C} / 1 \mathrm{~h}\end{array}$ & $7,8^{*}$ & 89,4 \\
\hline RT-PCR suco de laranja, $4 \times 10^{4}$ & $12,1^{*}$ & 136,4 \\
\hline $\begin{array}{l}\text { RT-PCR suco de laranja, } 4 \times 10^{4} / \\
99^{\circ} \mathrm{C} / 1 \mathrm{~h}\end{array}$ & $0,44^{*}$ & 4,7 \\
\hline $\begin{array}{l}\text { n-RT-PCR suco de laranja, } 4 \times 10^{4} / \\
99^{\circ} \mathrm{C} / 1 \mathrm{~h}\end{array}$ & $49,3^{* *}$ & 501,4 \\
\hline $\begin{array}{l}\text { RT-PCR suco de laranja, } 4 \times 10^{4} / \\
\text { inibidor } / 45^{\circ} \mathrm{C} / 2 \mathrm{~d}\end{array}$ & $0,77^{*}$ & 7,1 \\
\hline $\begin{array}{l}\text { n-RT-PCR suco de laranja, } 4 \times 10^{4} / \\
\text { inibidor } / 45^{\circ} \mathrm{C} / 2 \mathrm{~d}\end{array}$ & $39,3^{* *}$ & 410,6 \\
\hline $\begin{array}{l}\text { RT-PCR suco de laranja, } 4 \times 10^{4} / \\
\text { inibidor } / 99^{\circ} \mathrm{C} / 1 \mathrm{~h}\end{array}$ & $0,13^{*}$ & 2,3 \\
\hline $\begin{array}{l}\text { n-RT-PCR suco de laranja, } 4 \times 10^{4} / \\
\text { inibidor } / 99^{\circ} \mathrm{C} / 1 \mathrm{~h}\end{array}$ & $35,3^{* *}$ & 427,3 \\
\hline Negative control RT-PCR & ND & ND \\
\hline
\end{tabular}

ND: Não detectado

URF: Unidade Relativa de Fluorescência

n-RT-PCR: nested RT-PCR

* 294-bp ** 191-bp. 


\subsection{CONCLUSÕES}

O método eletroforético em microchips pode ser utilizado para a detecção e quantificação rápida e sensível de $A$. acidoterrestris viáveis em sucos de laranja por RT-PCR e nested RT-PCR, utilizando primers específicos para incrementar a sensibilidade.

Os primers internos desenhados a partir da região variável do $16 \mathrm{~S}$ rRNA de $A$. acidoterrestris (294 bp) foram utilizados para reações nested RT-PCR (191 bp), obtendo-se um limite de detecção de 0,1 UFC $\mathrm{mL}^{-1}$ na detecção de $A$. acidoterrestris. No entanto, estes primers não apresentaram especificidade para os controles de $A$. acidocaldarius e $A$. cycloheptanicus, os quais amplificaram regiões conservadas do $A$. acidoterrestris.

As análises de RT-PCR e nested RT-PCR foram capazes de detectar concentrações de 0,1 UFC $\mathrm{mL}^{-1}$ para culturas puras e 2 UFC $\mathrm{mL}^{-1}$ em sucos de laranja artificialmente inoculados. Um seguimento da viabilidade de esporos de $A$. acidoterrestris também foi estudado por testes de RT-PCR e nested RT-PCR. O grau de inibição com uma fração purificada de Sapindus saponaria na concentração de $200 \mathrm{mg} \mathrm{L}^{-1}$ incubada à $45{ }^{\circ} \mathrm{C}$ por 2 dias foi de $93,6 \%$, e a inibição foi melhorada quando incubada à $99^{\circ} \mathrm{C}$ por $1 \mathrm{~h}(98,7 \%)$.

Comparando com a inibição de temperatura direta de $99^{\circ} \mathrm{C}$ por $1 \mathrm{~h}$, teve uma diminuição da viabilidade de $96,3 \%$, ou seja, que ainda nesta temperatura os esporos sobrevivem, e que poderíamos continuar estudando o grau de inibição com temperaturas e concentrações diferentes de inibidores naturais. Este procedimento oferece varias vantagens nas análises de rotina para avaliar a qualidade de alimentos e, em particular, na indústria de bebidas cítricas. 
CAPÍTULO 3: ISOLAMENTO E CLASSIFICAÇÃO DE ALICYCLOBACILLUS spp. EM DIFERENTES SUCOS DE FRUTOS ÁCIDOS POR RAPD-PCR E ELETROFORESE CAPILAR EM MICROCHIPS. 


\subsection{INTRODUÇÃO}

$\mathrm{Na}$ detecção de microorganismos esporulados deteriogênicos em sucos ácidos, se necessita que a amostra receba um tratamento especial para ativação das células em estado de dormência e a germinação dos esporos. O procedimento usado, freqüentemente, é o aquecimento de suspensões das amostras em solução salina, soluções tamponadas ou água, por dez minutos sob temperatura de 80 a 85 ${ }^{\circ} \mathrm{C}$, sendo que isso ocasiona apenas a morte das células vegetativas. Muitas vezes, é necessário um cultivo de enriquecimento por um tempo determinado a uma temperatura adequada para que se obtenha o crescimento e a multiplicação das células, que se encontra em número reduzido, e, posteriormente, procede-se o plaqueamento em meio adequado (PRIEST, 1989; PINHATTI, 1999).

Os métodos comumente utilizados para o isolamento e a detecção de bactérias viáveis são: plaqueamento por profundidade (pour plate), plaqueamento por superfície (spread plate) e filtração em membrana. Os meios mais utilizados no isolamento de bactérias acidotermofílicas do gênero Alicyclobacillus spp. são: BAM (Bacillus acidocaldarius Medium), OSA (Orange Serum Agar), PDA (Potato Dextrose Agar), BAT (Bacillus acidoterrestris Medium) e YGS (Yeast Glucose Starch) sendo estes dois últimos meios bastante aplicados na indústria de cítricos.

No trabalho de pesquisa desenvolvido pela Fundação Tropical de Culturas Tropicais e ABEcitrus, foi feito o isolamento de bactérias esporuladas pertencentes ao gênero Alicyclobacillus em amostras de suco de laranja concentrado congelado (SLCC) e amostras do campo agrícola e fábrica. Foram realizados dois protocolos: o isolamento com enriquecimento para detecção de aliciclobacilos, e o plaqueamento direto das diluições para uma enumeração da quantidade de esporos presentes nas 
amostras. Os meios de cultura utilizados nos ensaios foram seletivos para o gênero. Algumas técnicas de plaqueamento foram testadas com o objetivo de obter crescimento favorável desses microorganismos (EGUCHI, 1999).

$\mathrm{Na}$ grande maioria das indústrias de sucos de laranja do estado de São Paulo, são adotados estes meios de isolamento: BAT (Bacillus acidoterrestris Medium) e YGS (Yeast Glucose Starch) (MOTOHIRO, 1994), sendo este último meio de cultura, o meio seletivo para a detecção de aliciclobacilos no Japão. Porém, o mercado brasileiro teve que se adaptar aos diferentes protocolos de detecção microbiológica exigido por cada empresa importadora de sucos de laranja concentrado.

A identificação de Alicyclobacillus spp. é realizada pela observação de características morfológicas das células e das colônias, crescimento sob diferentes temperaturas e pH, utilização de fontes de carbono e testes bioquímicos convencionais; como catalase, oxidase e produção de acetoína, entre outros.

Taxonomicamente, ácidos graxos $\omega$-ciclohexano e $\omega$-cicloheptano são componentes característicos das espécies Alicyclobacillus spp. (De ROSA, 1974; DEINHARD, 1987). Os microorganismos deste gênero apresentam ácidos graxos, alguns triterpenos pentacíclicos, hopanóides na fração glicolipídica da membrana celular. A presença dos lipídeos contendo hopanóides, esta relacionado a adaptações da membrana celular bacteriana, à situação termoacidofílica, ou seja, resistência ao aumento de temperatura e ao $\mathrm{pH}$ reduzido (OSHIMA, 1975; KANNENBERG, 1994).

No presente capítulo, será descrito o desenvolvimento das metodologias utilizadas para o isolamento de diferentes cepas, a partir de diferentes amostras de frutas e sucos ácidos. As cepas isoladas serão utilizadas para as análises de RAPD- 
PCR por eletroforese capilar em microchips, e encontrar o melhor primer para a classificação das Alicyclobacillus spp.

\subsubsection{Taxonomia do gênero Alicyclobacillus}

Alicyclobacillus spp. são organismos obrigatoriamente acidofílicos e seu crescimento ocorre entre $\mathrm{pH}$ 2,0 e 6,0. A temperatura de crescimento varia entre 40 e $70{ }^{\circ} \mathrm{C}$. Fatores de crescimento como vitaminas e fontes orgânicas de nitrogênio, podem ou não ser requeridos. As células são em forma de bastonetes com 0,3 a 0,8 $\mu \mathrm{m}$ de comprimento. $\mathrm{O}$ crescimento é aeróbico ou facultativamente anaeróbio. A coloração é Gram-positiva / Gram variável, seus endósporos são formados sob condições ambientais e nutricionais adversas.

Estas bactérias possuem algumas classes de compostos expostos em sua membrana celular. Os ácidos graxos presentes na matriz lipídica da célula contém, predominantemente, $\omega$-alicíclico, com cadeias de 6 a 7 carbonos. A principal quinona isoprenóide é uma menaquinona com sete unidades isoprênicas (MK-7). Outras classes de compostos, como os hopanóides, podem estar presentes assim como sulfanolipídios (WISOTZKEY, 1992).

\subsubsection{Alicyclobacillus acidocaldarius}

São organismos aeróbicos, bastonetes Gram-positivos formadores de endósporos, com 2 a $3 \mu \mathrm{m}$ de comprimento e 0,7 a $0,8 \mu \mathrm{m}$ de largura, formando cadeias curtas com 5 ou 6 células. $O$ esporo não é intumescido, possuem formas elipsoidais e são localizados terminalmente ou subterminalmente. Os esporos possuem resistência relativamente fraca ao calor. 
As colônias não são pigmentadas, são planas e possuem margens irregulares. Os ácidos graxos predominantes na membrana são os ácidos $\omega$ ciclohexil undecanóico (C:17) e $\omega$-ciclohexil tridecanóico (C:19) e contribuem com 50 e 90\% do total de ácidos graxos, respectivamente (DE ROSA, 1997; DEINHARD, 1987). Hopanóides e sulfanolipídeos estão presentes na membrana.

As fontes de carbono utilizadas pelas linhagens desta espécie são glicose, galactose, glicerol e ácido casamino. O crescimento não ocorre nas seguintes fontes de carbono: sorbitol, citrato, acetato, succinato e etanol. $\mathrm{O} \mathrm{pH}$ de crescimento é de 2,0 a 6,0 e a temperatura varia entre 45 e $70{ }^{\circ} \mathrm{C}$. Nenhum fator de crescimento é requerido. A principal menaquinona é MK-7. O conteúdo $\mathrm{G}+\mathrm{C}$ do DNA varia de 61,2 a $62,2 \mathrm{~mol} \%$. As principais fontes de isolamento são ambientes de fontes geotermais. A linhagem tipo é ATCC (American Type Culture Collection) 27009, DSM (Deutsche Sammlung von Mikroorganismen) 446, = CCT (Centro de Culturas Tropicais) 4385.

\subsubsection{Alicyclobacillus acidoterrestris}

São bastonetes formadores de endósporos, aeróbicos, Gram positivos/variável, com 2,9 a 4,3 $\mu$ m de comprimento e 0,6 a $0,8 \mu \mathrm{m}$ de largura. Os esporos são ovais, localizados na posição subterminal ou terminal. As colônias são circulares com pigmentação branco-amarelada, translúcida ou opaca. Fatores de crescimento não são requeridos. A temperatura ótima de crescimento varia entre menos de $35^{\circ} \mathrm{C}$ e mais que $55^{\circ} \mathrm{C}$, sendo a temperatura ótima de crescimento é cerca de 42 a $53^{\circ} \mathrm{C} . \mathrm{O}$ pH de crescimento varia entre 2,2 a 5,8. 
O crescimento não ocorre na presença de $5 \%$ de $\mathrm{NaCl}$. Os ácidos graxos $\omega$ ciclohexano são os ácidos predominantes nas membranas celulares. Hopanóides e sulfanolipídeos são presentes. A menaquinona MK-7 é predominante sendo que também se detecta MK-6. O conteúdo de $G+C$ do DNA varia entre 51,6 a 53,3 mol\%. A linhagem tipo da espécie é DSM 3922 (= CCT 4380). (WISOTZKEY, 1992)

\subsubsection{Alicyclobacillus cycloheptanicus}

São bastonetes formadores de endósporos, aeróbios, Gram positivos. O tamanho das células varia entre 2,5 a 4,5 $\mu \mathrm{m}$ de comprimento e 0,35 a 0,55 $\mu \mathrm{m}$ de largura. Os esporos são ovais, localizados na posição subterminal e o esporângio é levemente intumescido. As colônias são circulares, pequenas, com pigmentação amarela esbranquiçada e opaca.

Vários fatores de crescimento são necessários como metionina, pantotenato, isoleucina e vitamina B12. A temperatura de crescimento varia de 40 a $53{ }^{\circ} \mathrm{C}$, sendo que a temperatura ótima de crescimento é $48^{\circ} \mathrm{C}$. O pH de crescimento é entre $3,0 \mathrm{a}$ 5,5. O crescimento ocorre em meio contendo aminoácidos e açúcares.

Os principais ácidos graxos da membrana celular são o ácido $\omega$-cicloheptil undecanóico, $\omega$-cicloheptil tridecanóico e $\omega$-cicloheptil $\alpha$-hidroxi undecanóico. A menaquinona MK-7 é predominante, sendo que também se detecta a presença de MK-6 e MK-9. O conteúdo de $G+C$ de DNA varia entre 54,0 a 56,9 mol\%. A linhagem tipo é DSM 4006 (CCT 4382). (WISOTZKEY, 1992) 


\subsubsection{Alicyclobacillus hesperidum}

São células de 2,1 a 3,9 $\mu \mathrm{m}$ de comprimento e 0,50 a 0,70 $\mu \mathrm{m}$ de largura, forma de esporos ovais subterminais, bastonetes aeróbios Gram positivos. As suas colônias não apresentam pigmentação. A temperatura de crescimento esta entre 35 e $60{ }^{\circ} \mathrm{C}$, com temperatura ótima ao redor de 50 a $53{ }^{\circ} \mathrm{C}$. $\mathrm{O} \mathrm{pH}$ ideal para crescimento varia de 3,5 a 4,0.

Utiliza varias fontes de carbono, tais como hexoses e dissacarídeos. No caso de pentoses e polióis, com exceção de manitol e glicerol, não são utilizados como fontes de carbono. Diversos aminoácidos também podem ser utilizados como fontes de carbono.

Os principais ácidos graxos predominantes na membrana são os ácidos $\omega$ ciclohexil (C 17:0) e o $\omega$-ciclohexil (C 19:0). O conteúdo G+C esta entre 60,3 a 53,3 mol\%. Esta bactéria foi isolada de solos sulfatados em Furnas na ilha de São Miguel de Azores. A linhagem tipo da espécie é DSM 12489. (ALBUQUERQUE, 2000).

\subsubsection{Alicyclobacillus acidiphilus sp. nov.}

Uma nova bactéria termo-acidofílica foi isolada de bebidas ácidas que tiveram odor a guaiacol. São células aeróbias, Gram positivas, esporos em forma de bastonetes com dimensões de 0,9-1,1 × 4,8-6,3 $\mu \mathrm{m}$. Este microorganismo, linhagem TA-67 ${ }^{\top}$, cresce a temperaturas entre 20 a $55^{\circ} \mathrm{C}$ (temperatura ótima $50{ }^{\circ} \mathrm{C}$ ) e a pH com valores de 2,5 - 5,5 (ótimo pH 3,0). Apresenta ácidos graxos $\omega$-ciclohexano como maior predominância na membrana celular. O conteúdo de $G+C$ no seu DNA é de $54,1 \mathrm{~mol} \%$. 
Em função das evidêcias fenotípicas e filogenéticas, se concluiu que a linhagem $T A-67^{\top}$, representa uma nova espécie do gênero Alicyclobacillus, sendo adotado o nome de Alicyclobacillus acidiphilus. O tipo de linhagem é TA-67 ${ }^{\top}$ (DSM $14558^{\top}=$ IAM $14935^{\top}=$ NRIC $\left.6496^{\top}\right)($ MATSUBARA, 2002).

\subsubsection{Detecção e identificação de $\boldsymbol{A}$. acidoterrestris}

\subsubsection{Contagem de bactérias pelo método das diluições}

O método requer a distribuição de um inóculo da amostra em placa com meio de cultura adequado. Após alguns dias de crescimento, contam-se as colônias que cresceram na placa e, portanto, cada célula dará origem a uma colônia. Para facilitar a contagem, que é expressa em número de bactérias por mililitros de cultura, são realizadas diluições sucessivas da amostra que consiste na diluição de $1 \mathrm{~mL}$ da cultura de bactéria em $9 \mathrm{~mL}$ de caldo, a seguir $1 \mathrm{~mL}$ desta solução é diluída novamente em $9 \mathrm{~mL}$ de caldo e isso é repetido de maneira que as soluções fiquem cada vez mais diluídas, e fáceis de contar.

\subsubsection{Análise morfológica}

Entre as principais características das células bacterianas estão suas dimensões, forma, estrutura e arranjo. Estes elementos constituem a morfologia da célula. De acordo com a espécie, as células individuais são esféricas, em bastão ou espiraladas. Além disso, em certas espécies bacterianas, as células se dispõem em grupamentos; os mais comuns são: aos pares, em grumos, em cadeias e filamentos. 
É importante reconhecer esses padrões de arranjo, pois, muitas vezes, caracteriza uma categoria taxonômica ou um gênero, por exemplo (PELCZAR, 1980).

\subsubsection{Coloração Gram}

A técnica de Gram consiste no tratamento sucessivo de um esfregaço bacteriano com os reagentes cristal violeta e lugol, e posteriormente com safranina. Todas as bactérias, tanto as Gram-positivas quanto as Gram-negativas, absorvem o cristal violeta e o lugol de maneira idêntica, adquirindo a cor roxa devido à formação de um complexo composto pelas duas substâncias. Entretanto, ao serem lavadas com o álcool apresentam comportamento diferente, isto é, as Gram-positivas não se deixam descorar pelo álcool, adquirindo a cor avermelhada do corante, enquanto que as Gram-negativas ficam descoradas.

\subsubsection{Polimorfismo de DNA por amplificação aleatória (RAPD-PCR)}

A técnica denominada de RAPD (random amplified polymorphic DNA) ou APPCR - arbitrarily amplified PCR é uma variação da PCR que gera fragmentos de DNA polimórficos, exclusivos para um determinado microorganismo. Esta técnica utiliza somente um oligonucleotídeo com 10 bases em vez de um par de primers, e sua seqüência é construída ao acaso, o qual gera a amplificação de várias seqüências alvo desconhecidas. A reação de amplificação procede em condições de baixa estringência, permitindo que ocorra o pareamento entre os iniciadores e 0 DNA alvo, mesmo que não haja complementaridade total entre as duas seqüências (WELSH, 1990), 
Na Figura 3.1 observa-se que a localização do primer 2 e 5 se intercala à fita oposta complementar, produzindo a síntese do produto $\mathrm{B}$, isto é realizado da mesma forma para produzir os produtos A e C.

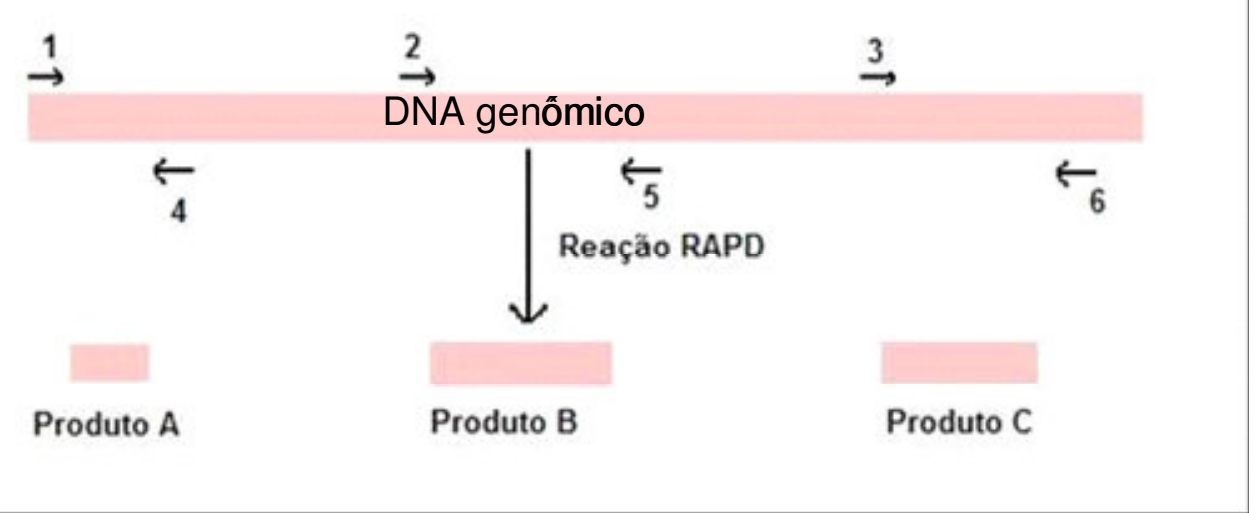

Figura 3.1: Diagrama da Reação de Polimorfismos de DNA por Amplificação Aleatória (RAPD).

A irrestrita adoção de marcadores moleculares do tipo RAPD na detecção, no diagnóstico e na determinação da diversidade genética deve-se, principalmente, à sua simplicidade de uso, rapidez, segurança e amplitude dos resultados gerados. Esta técnica tem se mostrado extremamente útil para medir e caracterizar a variabilidade genética e também para uma rápida identificação de diferentes diversidades de microorganismos (FUNGARO, 2000).

\subsection{OBJETIVOS}

> Isolar cepas do gênero Alicyclobacillus spp. a partir de sucos de frutas comercialmente pasteurizados assim como sucos in natura e superfície de frutas, e identificá-las por meio de técnicas microbiológicas e moleculares;

$>$ Realizar reações de RAPD-PCR a partir do DNA genômico das cepas isoladas; 
Analisar os produtos das reações de RAPD-PCR utilizando eletroforese capilar em gel com tecnologia microchips.

\subsection{MATERIAIS E MÉTODOS}

\subsubsection{Meios de isolamento e cultivo}

Os meios de isolamento e cultivo utilizados nos experimentos, assim como os procedimentos de preparo e condições de cultivo estão indicadas a seguir:

\subsubsection{Meio BAT (Bacillus acidoterrestris Medium)}

O meio BAT é composto de três soluções: Solução A, solução de elementos e solução de agar $1,5 \%$. A solução A contém $0,25 \mathrm{~g}$ de $\mathrm{CaCl}_{2} \cdot 2 \mathrm{H}_{2} \mathrm{O} ; 0,50 \mathrm{~g}$ de $\mathrm{MgSO}_{4} .7 \mathrm{H}_{2} \mathrm{O} ; 0,20 \mathrm{~g}$ de $\left(\mathrm{NH}_{4}\right)_{2} \mathrm{SO}_{4} ; 3,0 \mathrm{~g}$ de $\mathrm{KH}_{2} \mathrm{PO}_{4} ; 2,0 \mathrm{~g}$ de extrato de levedura; $5,0 \mathrm{~g}$ de glicose; $1,0 \mathrm{~mL}$ de solução de elementos traços e $500 \mathrm{~mL}$ de água Milli-Q. $\mathrm{O}$ pH da solução foi ajustado para $3,5 \mathrm{com}_{2} \mathrm{SO}_{4} 1 \mathrm{~N}$ ou $\mathrm{NaOH} 1 \mathrm{~N}$. Em seguida, a solução foi autoclavada a $120{ }^{\circ} \mathrm{C}$ por 15 min. A solução de elementos traço contém $0,25 \mathrm{~g}$ de $\mathrm{CoCl}_{2} \cdot \mathrm{H}_{2} \mathrm{O} ; 0,10 \mathrm{~g}$ de $\mathrm{ZnSO}_{4} .7 \mathrm{H}_{2} \mathrm{O} ; 0,20 \mathrm{~g}$ de $\mathrm{CuSO}_{4} \cdot 5 \mathrm{H}_{2} \mathrm{O} ; 0,03 \mathrm{~g}$ de $\mathrm{MnSO}_{4} \cdot \mathrm{H}_{2} \mathrm{O} ; 0,30 \mathrm{~g}$ de $\mathrm{H}_{3} \mathrm{BO}_{3} ; 0,03 \mathrm{~g}$ de $\mathrm{Na}_{2} \mathrm{MoO}_{4} \cdot 2 \mathrm{H}_{2} \mathrm{O} ; 0,02 \mathrm{~g}$ de $\mathrm{NiCl} .6 \mathrm{H}_{2} \mathrm{O}$ e $1000 \mathrm{~mL}$ de água Milli-Q. Finalmente a solução de agar 1,5\% foi preparada em 500 $\mathrm{mL}$ de água Milli-Q e autoclavada a $120{ }^{\circ} \mathrm{C}$ por 15 minutos. No preparo do meio sólido combinou-se a solução A e solução de ágar 3\% sendo que esta deve estar fundida. 


\subsubsection{Meio YGS (Yeast Glucose Starch)}

O meio YGS é composto de duas soluções: Solução A e solução de ágar $3,0 \%$. A solução A contém 2,0 $\mathrm{g}$ de extrato de levedura; $1,0 \mathrm{~g}$ de glicose; $2,0 \mathrm{~g}$ de amido solúvel e $500 \mathrm{~mL}$ de água Milli-Q. O pH da solução foi ajustado para 3,7 com $\mathrm{H}_{2} \mathrm{SO}_{4} 1 \mathrm{~N}$ ou $\mathrm{NaOH} 1 \mathrm{~N}$. Em seguida, a solução foi autoclavada a $120{ }^{\circ} \mathrm{C}$ por 15 min. A solução de ágar 3,0\% foi preparada em $500 \mathrm{~mL}$ de água Milli-Q e autoclavada a $120{ }^{\circ} \mathrm{C}$ por 15 min. No preparo do meio sólido combinou-se a solução $A$ e solução de ágar $1,5 \%$ sendo que esta deve estar fundida e ter concentração final de 1,5\%.

\subsubsection{Método Ehime}

Este método é utilizado para análise de sucos concentrados, o qual requer a diluição de $43 \mathrm{~g}$ do suco em $207 \mathrm{~mL}$ de água Milli-Q. As amostras foram ativadas por choque térmico à $85{ }^{\circ} \mathrm{C}$ durante $10 \mathrm{~min}$ e depois resfriadas até $30^{\circ} \mathrm{C}$ por $10 \mathrm{~min}$. $\mathrm{A}$ seguir são incubadas à $45{ }^{\circ} \mathrm{C}$ por três dias. Após o enriquecimento, $1 \mathrm{~mL}$ das amostras foram inoculadas por plaqueamento em profundidade, com meio YGS, em duplicata. As placas foram incubadas a $45{ }^{\circ} \mathrm{C}$ por cinco dias. $\mathrm{O}$ meio de cultura utilizado para a contagem é o YGS, tal como descrito no item 3.3.1.2.

\subsubsection{Isolamento e cultivo de Alicyclobacillus}

Foram utilizadas aproximadamente trinta amostras, entre sucos processados e superfícies de frutas ácidas provenientes de diversas marcas e regiões do estado de São Paulo e Minas Gerais, safra dos anos 2004 e 2005. Todas as amostras foram armazenadas em câmaras frias a $-20^{\circ} \mathrm{C}$, durante o tempo de realização dos experimentos. Na Tabela 3.1, apresentamos dezenove amostras que apresentaram 
detecção positiva com Alicyclobacillus spp, e que serviram para as análises de RAPD-PCR.

Sucos concentrados e diluídos de maracujá, laranja, abacaxi, tangerina e limão foram analisados por técnicas microbiológicas. Para a detecção e isolamento das diferentes linhagens de Alicyclobacillus spp. foram realizados com o método Ehime e os meios YGS e BAT, como pre-tratamento de incubação. Também foram avaliadas as contagens por plaqueamento com os meios YGS e BAT para todas as amostras.

Para a detecção e isolamento dos microorganismos nas superfícies de frutas, utilizamos laranjas, limões e maracujás procedentes de pomares e do comércio. Os pre-tratamentos e contagens para 0 isolamento dos microorganismos, foram realizados com os meios YGS e BAT a partir de $1 \mathrm{~kg}$ de amostras, variando as temperaturas e tempos de incubação.

Tabela 3.1: Amostras de sucos de frutas concentrados, diluídos e de superfície de frutas ácidas.

\begin{tabular}{|l|l|c|}
\hline \multicolumn{1}{|c|}{ Amostra/Suco } & \multicolumn{1}{c|}{ Procedência } & Código \\
\hline Concentrado de laranja Lanjal & Matão - SP & 1 \\
\hline Concentrado de laranja Nutricitrus & Matão - SP & 2 \\
\hline Diluído de maracujá da Fruta & Mogi das Cruzes - SP & 4 \\
\hline Diluído de maracujá Serigy & São Cristóvão - SE & 5 \\
\hline Diluído de laranja Maguary & Araguari - MG & 6 \\
\hline Superfície de frutos de maracujá & São Carlos - SP & 7 \\
\hline Concentrado de maracujá Maracujal & Matão - SP & 8 \\
\hline Concentrado de tangerina Nutricitrus & Matão - SP & 9 \\
\hline Concentrado de limão Limonjal & Matão - SP & lim \\
\hline Superfície de frutos de laranja & São Carlos - SP & Lfr \\
\hline Superfície de frutos de limão & São Carlos - SP & Lim \\
\hline Diluído de abacaxi Milani 1 & Matão - SP & 14 \\
\hline Diluído de abacaxi da Fruta 1 & Matão - SP & 15 \\
\hline Diluído de abacaxi da Fruta 2 & Mogi das Cruzes - SP & 16 \\
\hline Diluído de abacaxi Milani 2 & Mogi das Cruzes - SP & 17 \\
\hline Superfície de laranjas do pomar/solo & São Carlos - SP & T1 \\
\hline Suco de laranja in natura da rua 1 & São Carlos - SP & T2 \\
\hline Suco de laranja in natura da rua 2 & São Carlos - SP & T3 \\
\hline Superfície de laranjas do pomar/meio & São Carlos - SP & T4 \\
\hline
\end{tabular}




\subsubsection{Linhagens controle}

As linhagens de referência de Alicyclobacillus spp. utilizadas neste trabalho foram obtidas da Coleção de Culturas Tropicais (CCT) da Fundação "André Tosello", Campinas, SP e da empresa Cargill Agrícola S.A., listadas na Tabela 3.2. Todas estas cepas serviram como controles para realizar as reações de RAPD-PCR.

Tabela 3.2: Linhagens controle do gênero Alicyclobacillus spp.

\begin{tabular}{|l|l|l|l|}
\hline Linhagem & $\mathrm{n}^{\circ}$ CCT & Fonte & Código \\
\hline Alicyclobacillus acidoterrestris & 4384 & ATCC 49028 & $\mathrm{C}+2$ \\
\hline Alicyclobacillus acidocaldarius & 4385 & ATCC 43034 & $\mathrm{C}+3$ \\
\hline Alyciclobacillus cycloheptanicus & 4382 & ATCC 49028 & $\mathrm{C}+4$ \\
\hline Alicyclobacillus acidoterrestris & - & Cargill S.A. & $\mathrm{C}+1$ \\
\hline Alicyclobacillus acidoterrestris & & Cargill - Japão & $\mathrm{C}+5$ \\
\hline
\end{tabular}

CCT: Coleção de Culturas Tropicais.

ATCC: American Type Culture Collection.

\subsubsection{Detecção e enumeração de esporos de Alicyclobacillus spp. em amostras de suco concentrado}

Para o enriquecimento e detecção, os sucos concentrados foram tratados pelo método Ehime, como descrito no item 3.3.1.3. Os resultados foram dados em unidades formadoras de colônias por kg do produto (UFC/kg). 


\subsubsection{Detecção e enumeração de esporos de Alicyclobacillus em amostras de sucos diluídos}

Em frasco devidamente esterilizado, $90 \mathrm{~mL}$ de suco foram diluídos com $10 \mathrm{~mL}$ de meio de cultura líquido BAT. As amostras foram pasteurizadas a $80{ }^{\circ} \mathrm{C}$ durante 10 min e depois incubadas a $50{ }^{\circ} \mathrm{C}$ por $24 \mathrm{~h}$. A contagem foi realizada com $1 \mathrm{~mL}$ das amostras enriquecidas, por plaqueamento em profundidade com os meios YGS e BAT, em duplicata. As placas foram incubadas durante cinco dias a $45^{\circ} \mathrm{C}$ e $50{ }^{\circ} \mathrm{C}$, respectivamente.

\subsubsection{Detecção e enumeração de esporos de Alicyclobacillus em amostras de superfícies de frutas ácidas}

Para a detecção do microorganismo em superfícies de frutas foram pesadas 1 $\mathrm{kg}$ da fruta em sacos plásticos herméticos estéreis. Adicionou-se $100 \mathrm{~mL}$ do caldo de cultura YGS (pH 3,7) no saco plástico e iniciou-se a agitação das frutas de modo que todas fossem lavadas. O caldo da lavagem foi transferido a um frasco e pasteurizado a $80{ }^{\circ} \mathrm{C}$ por $10 \mathrm{~min}$. O enriquecimento das amostras foi realizado a 45 ${ }^{\circ} \mathrm{C}$ por três dias. Após o enriquecimento foi feito o plaqueamento por profundidade no meio ágar-YGS (pH 3,7) e depois as placas incubadas por cinco dias a $45^{\circ} \mathrm{C}$.

Para facilitar a contagem foram realizadas diluições sucessivas 1:10 da amostra e os resultados foram dados em unidades formadoras de colônias por mililitro do produto (UFC/mL). O número de UFC/mL será calculado por:

$$
\mathrm{UFC} / \mathrm{mL}=\frac{\mathrm{n}^{\circ} \text { colônias }}{\mathrm{V} \times \mathrm{F}}
$$


UFC = unidade formadora de colônias .

$n^{\circ}=$ número de colônias visualizadas na placa .

$\mathrm{V}=$ volume de amostra em $\mathrm{mL}$.

$\mathrm{F}=$ fator de diluição.

\subsubsection{Purificação e preservação das linhagens}

As colônias isoladas foram purificadas pelos métodos de diluições seriadas e de esgotamento por estrias na superfície das placas. Para as purificações das Alicyclobacillus, os plaqueamentos foram realizados com o meio de cultura YGS $(\mathrm{pH}$ 3,7 ) incubadas a $45{ }^{\circ} \mathrm{C}$ por 5 dias. As culturas foram avaliadas quanto à pureza, por meio da visualização das características das colônias no crescimento em placa, coloração de Gram e visualização microscópica.

Todas as purificações foram realizadas repetidamente até obter cepas totalmente puras. Uma vez purificadas, as cepas isoladas foram cultivadas no caldo de cultura YGS a um pH 3,7 e incubadas a $45{ }^{\circ} \mathrm{C}$ durante 72 horas. Após a purificação as células foram retiradas das placas e lavadas por centrifugação a 5000× g por 15 minutos e lavadas com solução salina acidificada estéril pH 3,7 por três vezes. As biomassas de células foram transferidas a micro tubos e depois codificadas e estocadas a $4{ }^{\circ} \mathrm{C}$ 


\subsubsection{Classificação filogenética por técnicas de RAPD-PCR}

\subsubsection{Extração do DNA genômico}

O DNA das cepas isoladas foi extraído conforme protocolo do kit Easy-DNA (Invitrogen) que consiste na centrifugação da amostra e retirada do sobrenadante seguida de ressuspensão dos pellets em tampão PBS $1 \times$ para eliminar formação de sais. Acrescentou-se $350 \mu \mathrm{L}$ da solução A do kit, agitou-se e incubou-se a solução a $65{ }^{\circ} \mathrm{C}$ por 10 minutos. A seguir adicionou-se $150 \mu \mathrm{L}$ da solução $\mathrm{B}$ e agitou-se vigorosamente até completa homogeneização da amostra. Adicionou-se então 500 $\mu \mathrm{L}$ de clorofórmio à solução homogeneizando-a até formação de emulsão.

Posteriormente as amostras foram centrifugadas para separação das fases sendo que a fase superior aquosa foi transferida para um microtubo novo. Acrescentou-se então $1 \mathrm{~mL}$ de etanol absoluto, agitou-se o conteúdo do tubo incubando-o a seguir em gelo por 30 min. 0 passo seguinte foi remover o etanol absoluto e lavar o precipitado com etanol $80 \%$ gelado por centrifugação.

Depois de seco, o pellet foi hidratado com tampão Tris-EDTA $(\mathrm{pH} 7,4)$ e digerido em solução de RNase (na concentração de $40 \mu \mathrm{g} / \mathrm{mL}$ ) para ressuspensão do pellet. Finalmente este foi incubado a $-20{ }^{\circ} \mathrm{C}$.

Além das diferentes cepas isoladas, também foram extraídas os DNA dos controles de Alicyclobacillus spp obtidos da Coleção de Culturas Tropicais André Tosello e da Empresa Cargill Agrícola S.A., especificados na Tabela 3.2. 


\subsubsection{Quantificação espectrofotométrica do DNA}

Realizou-se a quantificação do DNA genômico em espectrofotômetro Gene Quantpro da Amersham Bioscience, nas densidades ópticas de $A_{260}$ e $A_{280}$, características de DNA e proteínas, respectivamente.

A concentração de DNA na amostra é obtida pelo cálculo:

DNA $(\mu \mathrm{g} / \mathrm{mL})=$ valor da leitura em $A_{260 n m} \times 50 \times$ fator de diluição.

$1 \mathrm{OD}_{260 \mathrm{~nm}}=50 \mu \mathrm{g} / \mathrm{mL}$ de DNA

\subsubsection{Reação de RAPD - PCR}

Para a classificação e identificação das cepas isoladas do gênero Alicyclobacillus por RAPD, foram obtidos cinco oligonucleotídeos ou primers aleatórios para a construção das arvores filogenéticas e de consenso (Tabela 3.3).

As amplificações foram feitas com primers de seqüência aleatória da Amersham Pharmacia Biotech e da Operon Technologies. A reação foi realizada a um volume final de $13 \mu \mathrm{L}$ com os reagentes: Tampão de PCR 10×, $\mathrm{MgCl}_{2} 50 \mathrm{mM}$, dNTP $20 \mathrm{mM}$, primer 0,6 $\mu \mathrm{M}$, Taq-DNA polimerase $1,5 \mathrm{U}$ e $150 \mathrm{ng}$ do DNA genômico.

A RAPD procedeu no termociclador PTC-100 da MJ Research com desnaturação inicial a $94{ }^{\circ} \mathrm{C}$ por $1 \mathrm{~min}$, e 45 ciclos que compreendem em desnaturação a $94{ }^{\circ} \mathrm{C}$ durante $1 \mathrm{~min}$, intercalação do primer a $40{ }^{\circ} \mathrm{C}$ por $45 \mathrm{~s}$ e extensão a $72{ }^{\circ} \mathrm{C}$ por $1 \mathrm{~min}$, finalmente ocorre uma extensão final a $72{ }^{\circ} \mathrm{C}$ por 5 min.

Os produtos amplificados na reação foram separados em gel de agarose $1,5 \%$ a $74 \mathrm{~V} / \mathrm{cm}$ por aproximadamente $1 \mathrm{~h}$ e $30 \mathrm{~min}$. O marcador de tamanho de 
DNA utilizado para calcular os tamanhos de cada banda produzida foi o marcador de $1 \mathrm{~kb}$ (Invitrogen).

Tabela 3.3: Seqüência de primers utilizados na reação de RAPD-PCR.

\begin{tabular}{ll}
\hline Oligonucleotídeo & Seqüência \\
\hline P4 & 5' AAGAGCCCGT 3' \\
P5 & 5' AACGCGCAAC 3' \\
OP-E2 & 5' GGTGCGGCAA 3' \\
OP-E15 & 5' ACGCACAACC 3' \\
OP-E16 & 5' GGTGACTGTG 3' \\
\hline
\end{tabular}

\subsubsection{Eletroforese no Lab-on-a-Chip Agilent 2100 Bioanalyzer}

Para separar e caracterizar cada banda polimórfica produzida nas reações de RAPD-PCR, utilizou-se o equipamento Bioanalyzer 2100 Agilent Technologies e o kit DNA 7500 LabChip $^{\circledR}$. O protocolo detalhado está descrito no Capítulo 2, item 2.3.13. 


\subsection{RESULTADOS E DISCUSSÕES}

\subsubsection{Contagem em diferentes meios de cultivo por diferentes métodos}

O método e meios de cultura utilizados para o isolamento e contagem das Alicyclobacillus spp foram: Ehime, YGS e BAT. Estes métodos se diferenciaram pela temperatura no choque térmico e pela temperatura e tempo de incubação. Frente aos resultados obtidos nos experimentos preliminares da condição ótima de crescimento de Alicyclobacillus, o meio YGS à $45^{\circ} \mathrm{C}$ e pH 3,7 foi selecionado para a execução das etapas de detecção e isolamento das bactérias nas amostras adquiridas.

$\mathrm{Na}$ Tabela 3.4, observamos resultados obtidos com o método Ehime, e os meios de contagem BAT e YGS, para amostras de superfícies de maracujás, laranja e suco concentrado de laranja. Em todos os casos observamos, que o meio de contagem YGS, com incubação à $45{ }^{\circ} \mathrm{C} / 5$ dias, foi aquele que teve melhores resultados no crescimento de colônias. No entanto, com o meio BAT resultou ter menor crescimento de colônias, este fato pode ser atribuído à presença de sais e ácidos no meio de cultura, o que pode ter levado a alguns microorganismos injuriados à morte. Na mesma tabela, também percebemos a diferença entre a contagem de colônias na superfície de maracujás e de laranjas. A maior quantidade de bactérias presentes no maracujá deve-se à sua superfície bastante rugosa que permite o alojamento de Alicyclobacillus 
Tabela 3.4. Efeito dos diferentes métodos e meios de enriquecimento e contagem, na detecção de Alicyclobacillus spp. em amostras de sucos concentrados e superfície de frutas ácidas.

\begin{tabular}{lccc}
\hline \multicolumn{1}{c}{ Amostra } & $\begin{array}{c}\text { Método/Meio } \\
\text { Enriquecimento }\end{array}$ & $\begin{array}{c}\text { Meio } \\
\text { Contagem }\end{array}$ & $\begin{array}{c}\text { Contagem } \\
(\mathrm{UFC} / \mathrm{mL})\end{array}$ \\
\hline Superfície de maracujás & YGS & BAT & - \\
Superfície de maracujás & YGS & YGS & $1,5 \times 10^{3}$ \\
Superfície de maracujás & BAT & YGS & $2,9 \times 10^{2}$ \\
Superfície de maracujás & BAT & BAT & $4,9 \times 10^{1}$ \\
Superfície de laranjas & YGS & BAT & $4,5 \times 10^{2}$ \\
Superfície de laranjas & YGS & YGS & $9,1 \times 10^{2}$ \\
Superfície de laranjas & BAT & YGS & $4,5 \times 10^{1}$ \\
Superfície de laranjas & BAT & BAT & - \\
Suco concentrado de laranja & Ehime & BAT & $8,7 \times 10^{3}$ \\
Suco concentrado de laranja & Ehime & YGS & $2,6 \times 10^{5}$ \\
\hline
\end{tabular}

Com relação aos sucos concentrados, o método Ehime foi o empregado para a diluição e enriquecimento, e a contagem foi realizada com os meios BAT e YGS. Dentre estes, o método Ehime e o meio YGS foram os que melhor recuperaram os esporos, portanto, foi 0 método selecionado para 0 isolamento de sucos concentrados (Tabela 3.5).

Comparando-se os resultados obtidos entre sucos concentrados e diluídos, nota-se uma baixa concentração nos sucos diluídos analisados pelo meio BAT e YGS. Este fato está relacionado à baixa atividade da água ( $>40^{\circ}$ Brix) nos sucos concentrados, o que mantém em estado dormente esporos e as células viáveis, conseqüentemente, após serem processadas e ativadas pelo choque térmico, os 
microrganismos se multiplicam, apresentando um maior número de $\mathrm{UFC} / \mathrm{mL}$ do que os sucos já diluídos.

Tabela 3.5: Contagem de bactérias em sucos concentrados, diluídos e de superfícies de diferentes frutas ácidas.

\begin{tabular}{|c|c|c|c|}
\hline Código & Suco/amostra & Método/meio & $\begin{array}{l}\text { Contagem } \\
\text { (UFC/mL) }\end{array}$ \\
\hline 1 & Concentrado de laranja Lanjal & Ehime/YGS & $2,6 \times 10^{5}$ \\
\hline 2 & $\begin{array}{l}\text { Concentrado de laranja } \\
\text { Nutricitrus }\end{array}$ & Ehime/YGS & $5,8 \times 10^{3}$ \\
\hline 8 & $\begin{array}{l}\text { Concentrado de maracujá } \\
\text { Maracujal }\end{array}$ & Ehime/YGS & $1 \times 10^{2}$ \\
\hline 9 & $\begin{array}{l}\text { Concentrado de tangerina } \\
\text { Nutricitrus }\end{array}$ & Ehime/YGS & $2,9 \times 10^{3}$ \\
\hline $\lim$ & Concentrado de limão Limonjal & Ehime/YGS & $5,8 \times 10^{3}$ \\
\hline 4 & Diluído de maracujá da Fruta & BAT/YGS & $<10$ \\
\hline 5 & Diluído de maracujá Serigy & BAT/YGS & $5 \times 10^{1}$ \\
\hline 6 & Diluído de laranja Maguary & BAT/YGS & $4 \times 10^{1}$ \\
\hline 14 & Diluído de abacaxi Milani 1 & BAT/YGS & $<10$ \\
\hline 15 & Diluído de abacaxi da Fruta 1 & BAT/YGS & $<10$ \\
\hline 16 & Diluído de abacaxi da Fruta 2 & BAT/YGS & $<10$ \\
\hline 17 & Diluído de abacaxi Milani 2 & BAT/YGS & $<10$ \\
\hline 7 & Superfície de frutos de maracujá & YGS/YGS & $9,1 \times 10^{2}$ \\
\hline Lfr & Superfície de frutos de laranja & YGS/YGS & $4,5 \times 10^{2}$ \\
\hline Lim & Superfície de frutos de limão & YGS/YGS & $7,1 \times 10^{2}$ \\
\hline T1 & $\begin{array}{l}\begin{array}{l}\text { Superfície de laranjas do } \\
\text { pomar/solo }\end{array}\end{array}$ & YGS/YGS & $5,4 \times 10^{5}$ \\
\hline T2 & $\begin{array}{l}\text { Suco de laranja in natura da rua } \\
1\end{array}$ & YGS/YGS & $8 \times 10^{1}$ \\
\hline T3 & $\begin{array}{l}\text { Suco de laranja in natura da rua } \\
2\end{array}$ & YGS/YGS & $5 \times 10^{1}$ \\
\hline T4 & $\begin{array}{l}\text { Superfície de laranjas do } \\
\text { pomar/meio }\end{array}$ & YGS/YGS & $4 \times 10^{5}$ \\
\hline
\end{tabular}




\subsubsection{Caracterização morfológica e coloração Gram}

Após o isolamento, as cepas foram analisadas macro e microscopicamente quanto à coloração, forma, tamanho e odor. Todas as cepas apresentaram colônias de coloração creme-amarelada, forma circular, superfície lisa, borda perfeita, tamanhos variáveis e odor característico de guaiacol. Na Figura 3.2, observamos colônias de cepas isoladas de suco concentrado de laranja (1) que apresentou contaminação de $2,6 \times 10^{5}$, isto foi verificado após diluições sucessivas até 1:103.

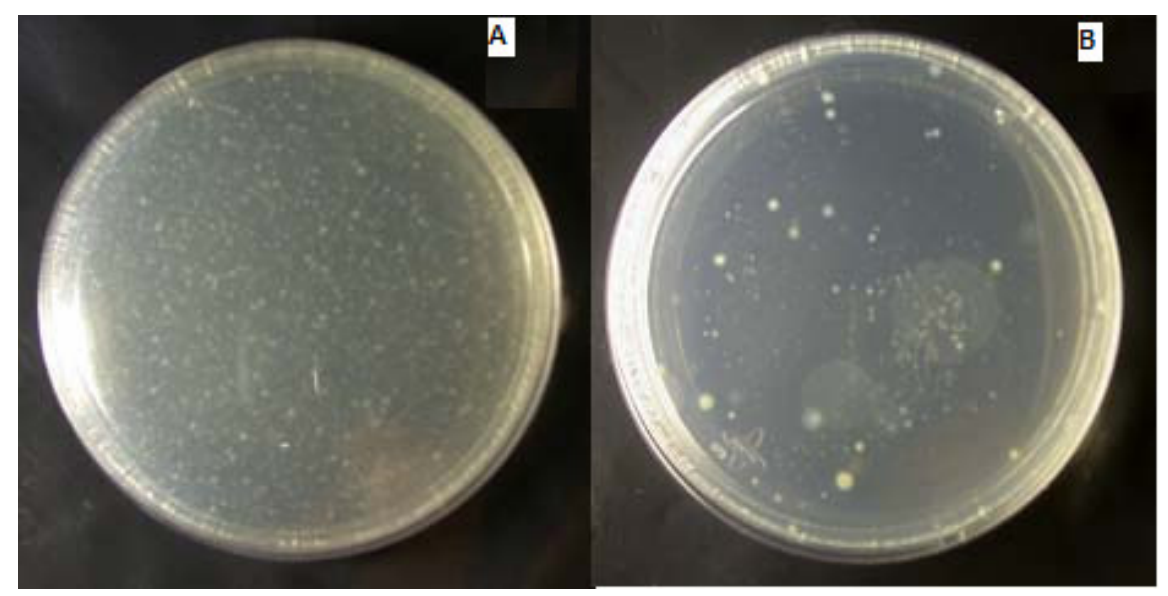

Figura 3.2: Características macroscópicas de colônias de Alicyclobacillus spp. isolada de sucos de laranja concentrado. Contagem em diluição 1:10 ${ }^{1}$ (A) e 1:10 (B).

A partir do teste de coloração de Gram, verificou-se diferenças morfológicas evidentes em algumas cepas. Na Figura 3.3, observamos os controles de $A$. acidoterrestris (ATCC 49028) e controle de A. acidoterrestris (C1) fornecida pela empresa Cargill Agrícola S.A. Estes controles foram identificados como Gram positivos, pela coloração azul violeta das células. No controle $\mathrm{C} 1$ também foi visualizada a presença de esporos. 

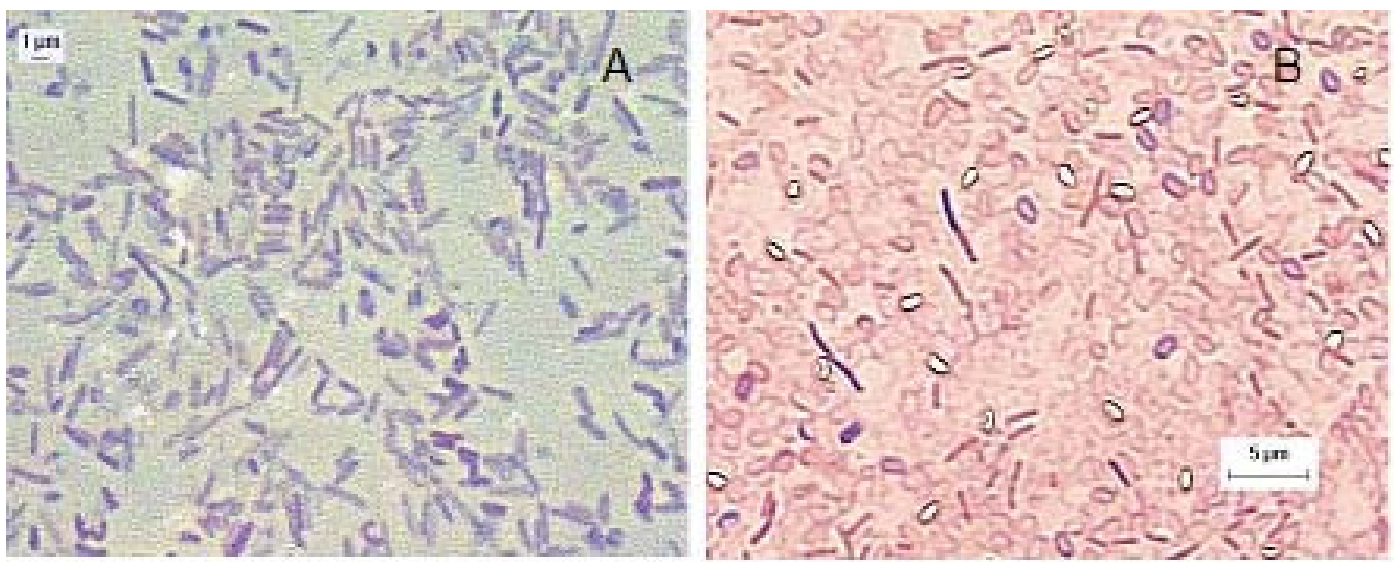

Figura 3.3: Características morfológicas visualizadas através de coloração Gram. (A) controle $\mathrm{C} 2$ correspondente a $A$. acidoterrestris e (B) controle $\mathrm{C} 1$ correspondente a A. acidoterrestris da empresa Cargill S.A.

$\mathrm{Na}$ Figura 3.4, comparamos duas cepas isoladas a partir do suco concentrado de limão (lim) e do suco diluído de abacaxi (15), com características de coloração Gram positiva. A cepa isolada a partir do suco diluído de abacaxi se caracterizou por ter células mais longas e mais espessas quando comparados aos demais. No caso da cepa do suco concentrado de limão, apresentou maior similaridade com os controles $\mathrm{C} 1$ e C2 pertencentes a $A$. acidoterrestris.

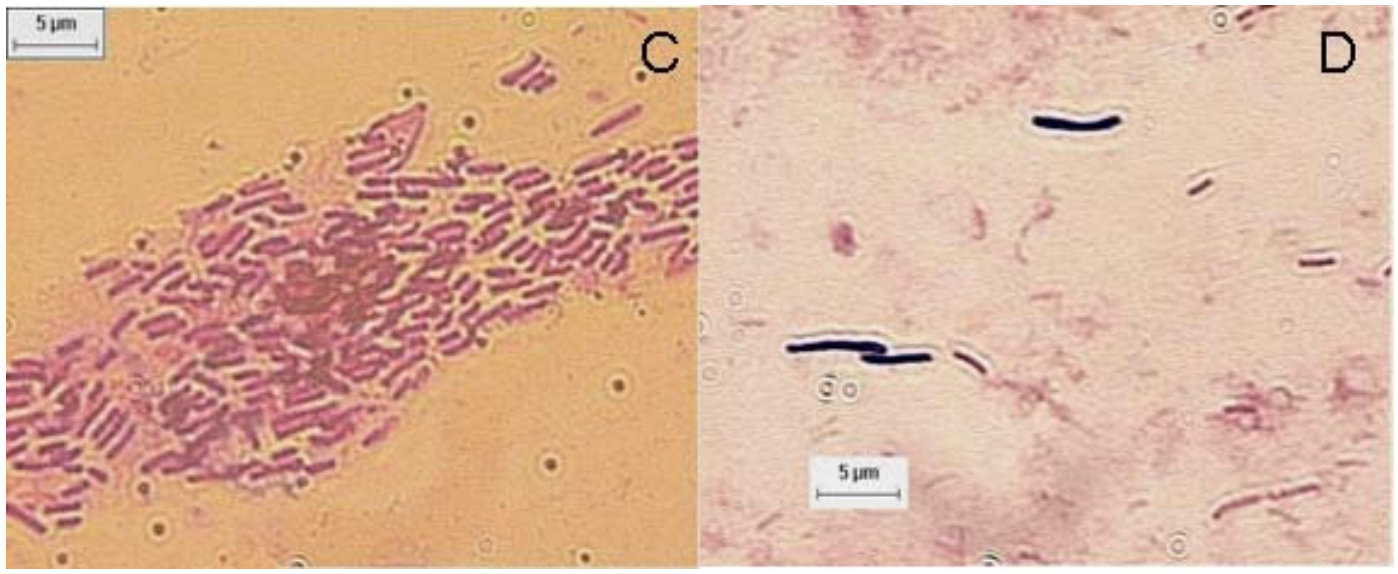

Figura 3.4: Características morfológicas, visualizadas através de coloração Gram. (C) cepa isolada de suco concentrado de limão, (D) cepa isolada de suco diluído de abacaxi. 


\subsubsection{Extração e quantificação de DNA de cepas isoladas}

As extrações do DNA de todas as cepas isoladas e controles tiveram bons rendimentos. As extrações realizadas com o kit Easy DNA (Invitrogen) teve relações de $A_{260} / A_{280}$ entre 1,7 e 2,0, o que indicou o alto grau pureza e livre de contaminação com proteínas. Todas as amostras do DNA genômico foram testadas para análise de RAPD-PCR com cinco primers diferentes, realizando-se posteriormente sua classificação filogenética.

\subsubsection{Métodos eletroforéticos para análise de RAPD-PCR}

Os produtos amplificados na RAPD-PCR com os cinco primers analisados, apresentaram fragmentos com diferentes bandas polimórficas variando os seus tamanhos entre 300 e 3000 bp. A visualização de todos os fragmentos foi verificada pelos géis virtuais e eletroferogramas gerados no equipamento Bioanalyzer 2100 . Com a eletroforese em placa de gel de agarose $1,5 \%$ não se obteve uma boa resolução e sensibilidade na detecção dos polimorfismos (figuras não apresentadas). Utilizando $o$ método de eletroforese capilar em microchip, observaram-se com melhor resolução as diferenças polimórficas entre todos os controles e cepas isoladas.

$\mathrm{Na}$ Figura 3.5, observamos o gel virtual com fragmentos produzidos com o primer $\mathrm{P} 4$. Todas as cepas isoladas produziram bandas polimórficas, com tamanhos que variaram entre 295 até $3670 \mathrm{bp}$, com um fragmento em comum de $750 \mathrm{bp}$, que se repetiram na maioria das cepas, e incluso os controles. As cepas provenientes de sucos concentrado e diluído de laranja $(1,2,6)$ e sucos diluídos de maracujá $(4,5)$ apresentaram similaridades muitos próximas, com bandas características entre 700 e 200 bp. No entanto, o primer P4 não pode ser utilizado para a detecção e 
diferenciação entre as diferentes cepas, devido a que os controles C2, C4 e a amostra de superfície de limões não apresentaram amplificação positiva nas reações de RAPD-PCR.

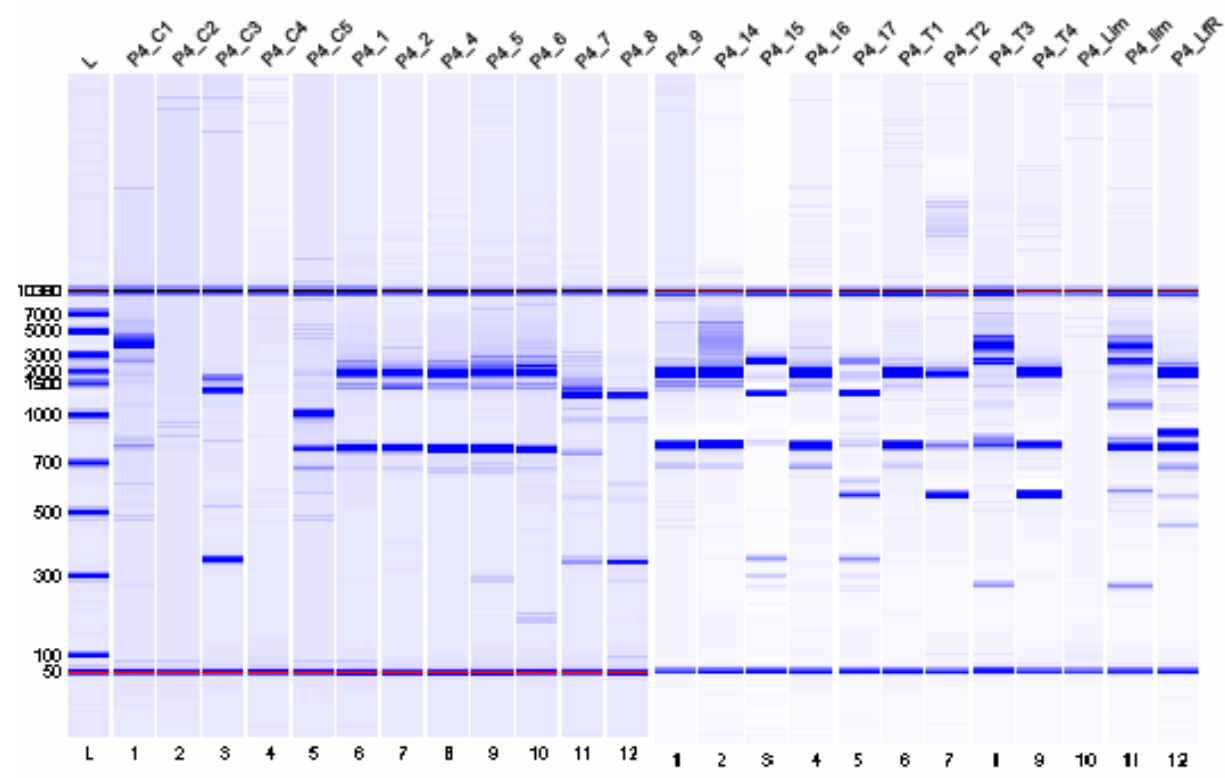

Figura 3.5: Análise eletroforética (gel virtual) dos produtos de amplificação do RAPDPCR das vinte e quatro cepas isoladas, analisadas com o primer P4: $L$ (marcador de tamanho de DNA) e as amostras estão codificadas segundo a Tabela 3.1.

Uma comparação entre três cepas controles de Alicyclobacillus spp. com o primer P5 foi realizado para comprovar os polimorfismos entre estas linhagens. Este primer mostrou que existe heterogeneidade genética entre as linhagens controles de A. acidoterrestris (C1), A. acidocaldarius (C3) e A. cicloheptánicus (C4), observandose três bandas polimórficas bem diferenciadas (240, 539 e 687 bp). Somente a banda de 1420 bp teve homogeneidade ou não polimorfismo devido ao seu mesmo gênero Alicyclobacillus spp. A cepa de suco de laranja in natura obtido no comercio da rua teve uma similaridade genética com a $A$. acidoterrestris (C1), obtendo-se o mesmo número de fragmentos não-polimórficos (Figura 3.6). 


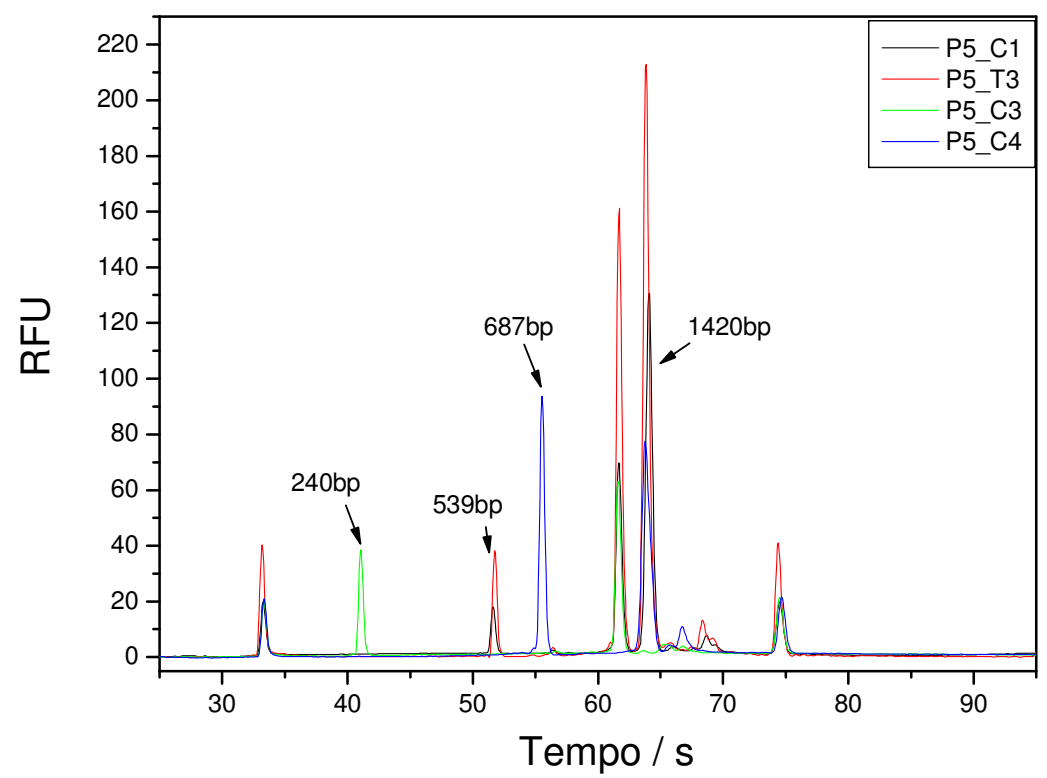

Figura 3.6: Eletroferograma de produtos de RAPD com o primer P5. Comparação entre os controles $A$. acidoterrestris (C1), A. acidocaldarius (C3), A. cicloheptánicus C4 e uma cepa isolada de suco de laranja in natura, analisados no Bioanalyzer 2100 Lab-on-a-Chip.

As reações de RAPD produzidas com o primer E2 demonstraram maior número de polimorfismos em comparação aos primers $\mathrm{P} 4$ e $\mathrm{P} 5$, estes resultados puderam diferenciar claramente a diferença filogenética entre as cepas da superfície de limões (Lim) e as cepas de suco concentrado de laranja (2), suco diluído de abacaxi (15) e controle $A$. acidoterrestris (C2). Na Figura 3.7, observamos um fragmento não polimórfico (1324 bp) característico das amostras C2, 2 e 15. No entanto, a cepa de superfície de limões (Lim) apresentou polimorfismos com fragmentos menores a 770bp. 


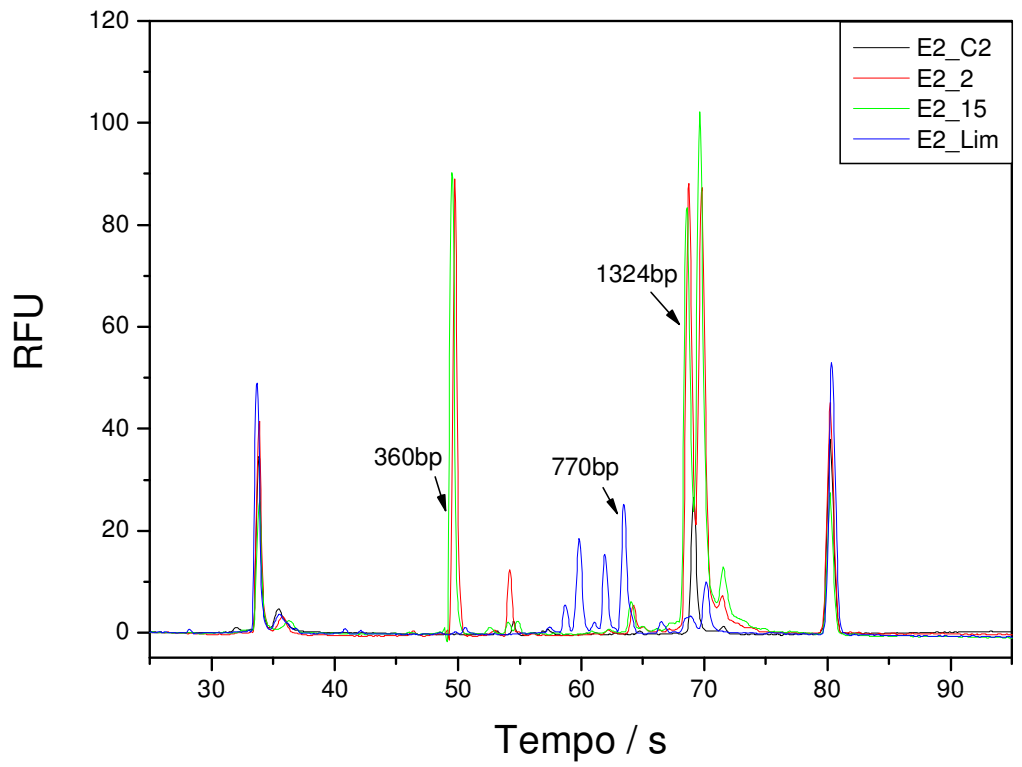

Figura 3.7: Eletroferograma de produtos de RAPD com o primer E2. Comparação entre $A$. acidoterrestris (C2), suco concentrado de laranja (2), suco diluído de abacaxi (15) e cepa isolada de superfície de limões, analisados no Bioanalyzer 2100 Lab-on-a-Chip.

As análises realizadas com o primer E15 também apresentaram polimorfismos que diferenciaram as cepas isoladas. Observaram-se diferenças polimórficas entre as cepas de superfície de laranjas do pomar/solo (T1) e de superfície de laranjas do comercio (Lfr), com respeito às cepas de suco concentrado de laranja e superfície de laranjas do pomar/meio. Os polimorfismos variaram entre 294 e 1491 bp, sendo os fragmentos de 294 e 975 bp as mais características entre elas (Figura 3.8). Contudo, podemos observar diferenças polimórficas entre todas as cepas provenientes de superfícies de frutas colhidas dos pomares e do comercio, e que tem similaridades próximas com as cepas presentes nos sucos processados de laranja. 


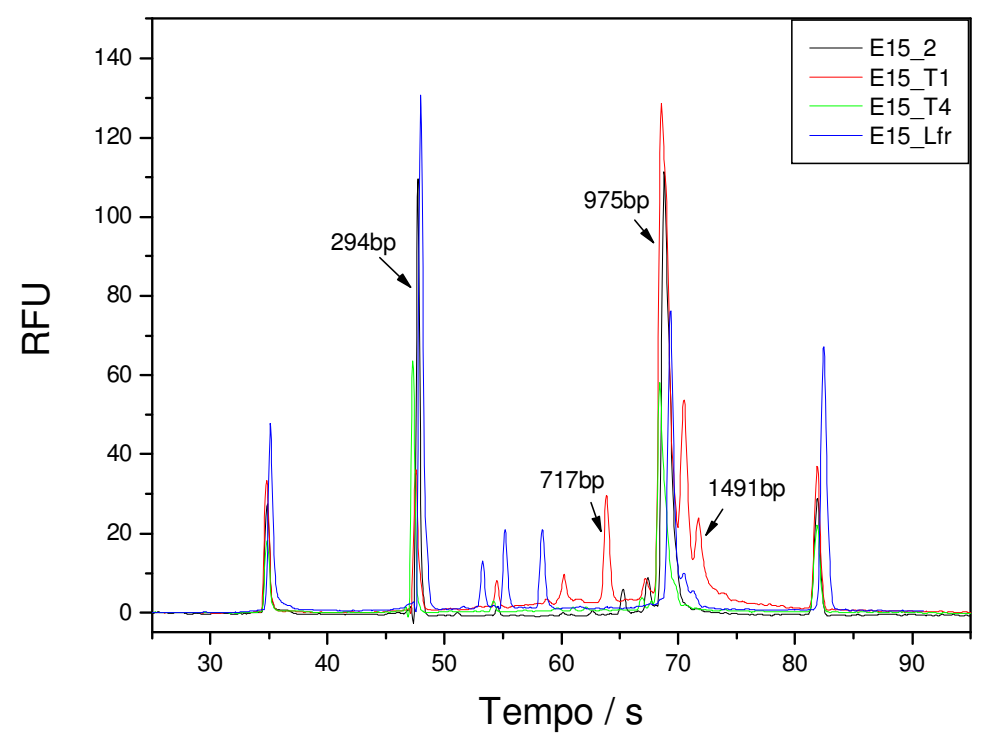

Figura 3.8: Eletroferograma de produtos de RAPD com o primer E15. Comparação entre cepas de suco concentrado de laranja (2), superfície de laranjas do pomar do solo e do meio (T1 e T4) e superfície de laranjas do comercio, analisados no Bioanalyzer 2100 Lab-on-a-Chip.

Na Figura 3.9, observamos as comparações de fragmentos produzidos com o primer E16, neste caso o controle de C5 (cepa extraída do Japão) teve maior similaridade com os sucos concentrados e diluídos de laranja $(2,6)$ respectivamente. O controle C5 também apresentou similaridade com as amostras de sucos diluídos de maracujá e abacaxi $(4,5,14,17)$, estes resultados foram comprovados com os primers anteriores. No entanto, foram observados polimorfismos gerados pelas cepas de superfície de maracujás (7) e suco concentrado de limão (lim), com fragmentos característicos de 481 e 700 bp, respectivamente. 


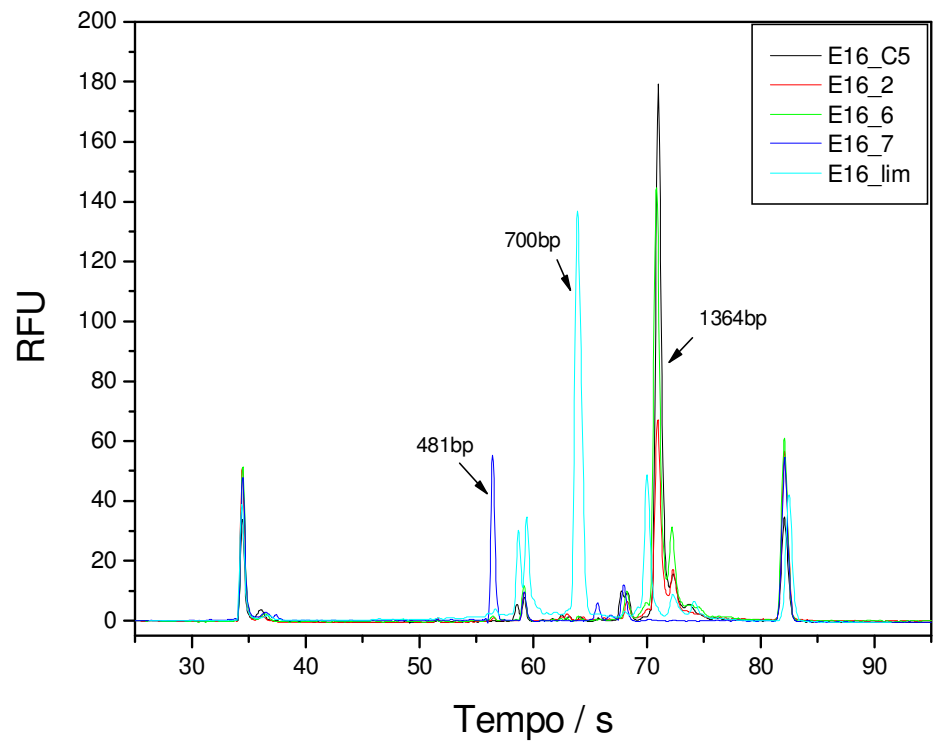

Figura 3.9: Eletroferograma de produtos de RAPD com o primer E16. Comparação entre o controle extraído do Japão (C5) e as cepas isoladas de suco concentrado de laranja (2), suco diluído de laranja (6), superfície de maracujás (7) e suco concentrado de limão (lim), analisados no Bioanalyzer 2100 Lab-on-a-Chip.

\subsection{CONCLUSÕES}

O isolamento de bactérias acidotermofílicas Alicyclobacillus spp. em sucos e superfícies de frutas ácidas, foi influenciada pelo choque térmico, temperatura e tempos de incubação no pré-tratamento. O método recomendado para o isolamento de bactérias em sucos concentrados e diluídos foi o Ehime e BAT, respectivamente. O meio YGS apresentou melhores condições de crescimento nas cepas isoladas.

A ocorrência de Alicyclobacillus spp. foi constatada pelo isolamento e detecção de dezenove cepas de frutas concentrados, diluídos e em superfícies de frutos ácidos, provenientes do comercio e de pomares; evidenciando uma distribuição do gênero Alicyclobacillus no estado de São Paulo. A detecção destes organismos nos sucos não foi associada à deterioração ou qualquer alteração do produto, devido a que não apresentaram cheiro e odor característicos, o que indicou que a deterioração seja incidental. 
A classificação molecular das dezenove cepas isoladas foi estudada utilizando cinco primers aleatórios em reações de RAPD-PCR e eletroforese capilar em microchips (Bioanalyzer 2100, Agilent Technology), os quais geraram diversos fragmentos polimórficos.

Os primers que produziram melhores fragmentos com diferenças polimórficas foram o P5, E2 e E15, demonstrando que estes primers podem servir como marcadores moleculares para a identificação e detecção de bactérias pertencentes ao gênero Alicyclobacillus. Segundo as análises eletroforéticas, as cepas de suco concentrado e diluído de laranja $(1,2,6)$ suco concentrado de limão (lim) e suco de laranja in natura (T2, T3), apresentaram similaridades genéticas com as cepas padrão $\mathrm{C} 1$ e C2, correspondentes a $A$. acidoterrestris. No entanto, as cepas da superfície de limões (Lim) e superfície de maracujás (7) que apresentaram diferenças polimórficas ao comparar-se com o controle de A. acidoterrestris.

As técnica RAPD-PCR e eletroforese capilar em microchips podem ser utilizadas como ferramentas na identificação e classificação de Alicyclobacillus spp., devido a melhor resolução, sensibilidade e pouco tempo nas análises (30 min) dos polimorfismos gerados. 
CAPÍTULO 4: ANÁLISE FILOGENÉTICA DE ALICYCLOBACILLUS spp. DE AMOSTRAS DE SUCOS DE FRUTOS ÁCIDOS UTILIZANDO TÉCNICAS DE RAPD-PCR E SEQÜENCIAMENTO 


\subsection{INTRODUÇÃO}

O uso extensivo de dados moleculares em estudos de filogenia é uma conseqüência do desenvolvimento de várias técnicas em biologia molecular. Nos últimos anos, se concluiu que a maioria das diferenças qualitativas entre dados genotípicos e fenotípicos facilitam o uso de seqüência de dados para estudos filogenéticos (OLSEN, 1993).

A filogenia molecular é o estudo da evolução e desenvolvimento das espécies. A comparação das seqüências de algumas macromoléculas é a forma mais precisa e confiável para inferir sobre as relações filogenéticas. Esses dados são preferidos sobre outros métodos moleculares por possuir proximidades evolutivas, devido a que permitem interpretações quantitativas e diretas, além de que vão formando uma crescente base de dados para subseqüentes referências.

Há cerca de quinze anos atrás, foi proposto o uso de seqüências do $16 \mathrm{~S}$ rRNA para estudos filogenéticos. As análises das seqüências do 16S rRNA, têm se tornado desde então, um método padrão para estudos filogenéticos de microrganismos (OLSEN, 1993). Baseando-se em dados do 16S rRNA, Woese e colegas, em 1990, propuseram mudar a classificação já existente da vida; dos domínios procariótico e eucariótico em uma classificação de três domínios, Archea, Bactéria e Eucarya (WOESE, 1990).

\subsubsection{O Gene 16S rRNA}

O ribossomo da E. coli possui uma massa de $2.5 \times 10^{6}$ Da e um coeficiente de sedimentação de $70 S$. O ribossomo $70 S$ esta constituído de duas subunidades diferentes em tamanho, com valores de sedimentação (Svedberg) de 30S e 50S. A 
subunidade pequena (30S) consiste de uma molécula de 16S rRNA e 21 proteínas diferentes, enquanto que a subunidade maior (50S) contém uma de 5S rRNA e outra de $23 \mathrm{~S}$ rRNA, com 31 proteínas diferentes. O 16S rRNA da E. coli, consiste de 1542 nucleotídeos, dos quais o 46\% estão emparelhados entre si.

A estrutura primaria do $16 \mathrm{~S}$ rRNA esta composta por regiões alternadas de alta e baixa variabilidade. As regiões com seqüências variáveis contêm informação de baixo nível filogenético, enquanto que, as regiões com seqüências conservadas contêm informação dos eventos evolutivos. Existe uma grande quantidade de cópias de rRNA em uma bactéria que esteja em fase de crescimento. Dessa forma, o rRNA é um excelente marcador molecular para a reconstrução da maioria das relações filogenéticas (FRY, 1991).

Para a amplificação do $16 \mathrm{~S}$ rRNA, as regiões conservadas facilitam o desenho de oligonucleotídeos iniciadores (aproximadamente de 20 nt). Quando se pretende amplificar o 16S rRNA completo, se utilizam primers desenhados em base a seqüências conservadas próximas aos extremos $5^{\prime}$ e $3^{\prime}$ do gene, que produzem amplicons de aproximadamente 1500 bp. Para a identificação de uma bactéria a nível de espécie, não se requer necessariamente o seqüenciamento do $16 \mathrm{~S}$ rRNA completo. De fato, embora existam posições filogeneticamente informativas ao longo de todo o gene, a maior variabilidade se concentra nas primeiras 500 bases nucleotídicas, correspondentes ao extremo 5’ (PATEL, 2000).

O gene 16S rRNA tem sido determinado para um grande número de linhagens. GenBank, o maior banco de dados de seqüências, tem aproximadamente 20 milhões de seqüências depositadas, das quais 90000 pertencem ao gene $16 \mathrm{~S}$ rRNA. Isso significa que existem um grande número seqüências depositadas para comparação de novas linhagens desconhecidas (CLARRIDGE, 2004). 


\subsubsection{Inferência Filogenética}

O alinhamento nas seqüências é o primeiro passo nas análises filogenéticas. Um alinhamento é obtido pela ordenação de espaços que correspondem a inserções ou remoções, para se obter a homologia posicional entre as seqüências. O alinhamento manual é ainda considerado dos mais exatos, mesmo, apesar do enorme número de programas de computação disponível para este fim. Não existem programas computacionais que alinhem automático e corretamente as seqüências. Existem diversos métodos para deduzir uma árvore filogenética a partir de uma seqüência alinhada. Os três métodos mais comuns são; Máxima Semelhança (MS), Máxima Parcimônia (MP) e o método de Matriz de Distâncias (LI, 1991). O método de Máxima Semelhança baseia-se em modelos evolutivos explícitos de substituição de nucleotídeos. Esses modelos são avaliados quanto a sua probabilidade de explicar um conjunto de dados de forma que reflita a história evolutiva mais verossímil. O princípio da Máxima Parcimônia é a hipótese mais simples, ou seja, aquela em que a árvore que apresente o menor número de passos será a escolhida para explicar um determinado conjunto de dados.

Os métodos de distância se baseiam em dois passos, o primeiro passo é a redução de variações entre seqüências alinhadas a valores de distância dispostos em uma matriz. No segundo passo, estes valores são utilizados na reconstrução filogenética. Um dos métodos de distância mais comuns é a chamada distância $p$, que expressa o número de sítios variáveis entre duas seqüências com relação ao total de sítios comparados. Além deste, existem também muitos outros modelos evolutivos utilizados para o cálculo de distâncias genéticas, como o Jukes-Cantor, Kimura 2 parâmetros, Tajima e Nei e Tamura 3 parâmetros. Na reconstrução filogenética, os algoritmos mais utilizados são o UPGMA e o neighbor joining, que 
realizam uma série de cálculos com a matriz de distância gerada a partir do alinhamento, para estimar a árvore filogenética (SAITOU, 1987).

Entre os vários métodos desenvolvidos para se investigar o nível de suporte para uma filogenia, o bootstrap é um dos mais utilizados, devido à facilidade de implementação e interpretação. Esse método se baseia na perturbação aleatória do conjunto de dados em um grande número de vezes (100 - 1000), seguida do cálculo de uma árvore para cada sub-réplica. O consenso de todas as árvores deveria indicar quais ramos são mais bem apoiados pelos dados em questão. O método se baseia na suposição de que pequenas modificações nos dados não diminuirão a capacidade de se encontrar os grupamentos se estes estiverem bem representados por esses dados. Assim, agrupamentos com baixos valores de bootstrap são aqueles que deixaram de ser inferidos em muitas sub-réplicas, o que sugere baixo suporte dos dados para esses grupos. Entretanto, é bom observar que os valores obtidos não indicam a probabilidade de que os grupamentos sejam corretos filogeneticamente, uma vez que diferentes seqüências podem determinar diferentes grupos, dependendo do caso analisado (FELSENSTEIN, 1985; SWOFFORD, 1996).

Uma vez obtidas as seqüências, estas devem ser alinhadas corretamente. Para tal, apesar de haver muitos programas computacionais que realizam esta tarefa, os alinhamentos devem ser verificados manualmente. Entretanto, alinhamentos automáticos pode ser um primeiro passo. Essa etapa é de extrema importância, pois um alinhamento errado comprometerá toda a análise. Para um alinhamento coerente, devem-se conhecer os diferentes tipos de mutações e substituições de nucleotídeos. Mutações ocorrem ao acaso em qualquer parte do genoma, modificando a seqüência de nucleotídeos na cadeia original de DNA, estas mutações podem ser por transição ou transversão (substituição de purina por 
pirimidina ou vice-versa, no DNA ou RNA), deleção/inserção e inversão. Substituições referem-se a regiões codificantes e podem ser sinônimas (quando não há alteração do aminoácido codificado), não sinônimas (quando há alteração) e sem sentido (quando um códon de parada é gerado).

Atualmente existem diversas bases de dados, algumas públicas, cujo aceso é livre na internet, como GenBank NCBI (National Center for Biotechnology Information), EMBL (European Molecular Biology Laboratory), RDP (Ribosomal Database Project), RIDOM (Ribosomal Differentiation of Medical Microorganisms) e outras privadas, como MicroSeq (Applied Biosystems) e SmartGene IDNS (Integrated Database Network System).

\subsubsection{Análise de Similaridade Genética}

O conhecimento da evolução das espécies e a relação entre elas são de extrema importância para a conservação e utilização dos recursos genéticos bem como para estudos de padrões evolucionários da diversidade biológica. Tais estudos incluem a Taxonomia (classificação dos organismos com base em similaridades de estruturas ou características) e a Filogenia.

A Filogenia lida com a identificação e entendimento das relações entre as espécies que resultam da evolução. Sob a premissa que as espécies evoluem de um ancestral comum, as espécies mais próximas têm mais características em comum do que as mais distantes. A sistemática filogenética é usada para identificar características similares e definir a relação evolucionária, incluindo genes ou fragmentos de DNA. Com base nessas relações, árvores filogenéticas são desenvolvidas mostrando o grupamento dos organismos. 
Existem dois tipos de análises utilizadas para o desenvolvimento de árvores filogenéticas: os métodos fenéticos e cladísticos. Os métodos fenéticos utilizam medidas de distância, que consolidam estatisticamente as diferenças entre os caracteres em um número. Uma matriz de distância entre todos os possíveis pares do grupo de estudo é criada e, árvores são desenvolvidas agrupando aqueles com menor diferença em um dendograma.

Os métodos cladísticos calculam árvores para cada caráter e então indicam a melhor árvore através da determinação daquela que requer menor número de mudanças (parcimônia) ou aquela mais provável estatisticamente (máxima verossimilhança).

A técnica conhecida UPGMA é o método mais simples de construção de árvores filogenéticas a partir de dados de distância. Para isso, emprega um algoritmo seqüencial de agrupamento, no qual as relações são identificadas em ordem de similaridade, e a árvore é construída passo a passo. Primeiro identifica-se entre todas as unidades estudadas as duas mais similares e esta é tratada como se fosse uma unidade. A seguir identifica-se outra unidade com maior similaridade, e assim por diante.

Quando uma análise produz dendogramas distintos, pode-se tentar representar a concordância entre as diferentes topologias por meio de uma árvore de consenso. Uma árvore de consenso é uma árvore que sintetiza um conjunto de árvores filogenéticas referentes a um determinado grupo de organismos. É importante ressaltar que a árvore de consenso não é a estimada filogenia para os organismos em estudo. Na verdade, essa árvore é utilizada para que possamos avaliar o quão boa é a filogenia obtida pelo conjunto de dados original. Essa avaliação é feita com base no suporte de bootstrap dado aos grupos inseridos na 
árvore de consenso. O método de bootstrap é uma técnica utilizada para medir a incerteza na estimativa de parâmetros (BELO 2005).

\subsubsection{Alinhamento de Seqüências}

O seqüenciamento de ácidos nucléicos tem demonstrado ser um dos métodos mais úteis para inferir a história filogenética dos microorganismos. O maior atrativo desta técnica se baseia em que os caracteres analisados (nucleotídeos) são as unidades básicas de informação, em que o banco de dados que pode se obter é imenso. Para utilizar as seqüências nucleotídicas em estudos filogenéticos, as seqüências devem ser alinhadas. O número e tamanho das seqüências que dever ser alinhadas dependem do nível de comparação elegido.

O alinhamento de seqüências possui uma diversidade de aplicações na bioinformática, sendo considerada uma das operações mais importantes desta área. Este método de comparação procura determinar o grau de similaridade entre duas ou mais seqüências, ou a similaridade entre fragmentos destas seqüências. No caso de mais de duas seqüências o processo é denominado alinhamento múltiplo.

Existem vários programas de computador que realizam esta tarefa e a grande maioria deles pode ser utilizado on-line. Como por exemplo, temos os programas: ClustalW, Multialin, FASTA, BLAST 2 Sequences, etc. O processo de alinhamento consiste em introduzir espaços (gaps) entre os monômeros de uma ou mais seqüências a fim de obter o melhor alinhamento possível. A qualidade do alinhamento é determinada pela soma dos pontos obtidos por cada unidade pareada (match) menos as penalidades pela introdução de gaps e posições não pareadas (mismatch). 
Quanto à região analisada, o alinhamento de seqüência pode ser classificado em dois tipos: alinhamento global e alinhamento local (Figura 4.1). No alinhamento global, as seqüências envolvidas devem ser alinhadas de um extremo a outro, dando origem a apenas um resultado. No alinhamento local, procura-se alinhar apenas as regiões mais conservadas, independente da localização relativa de cada região em sua seqüência. Consequentemente, este alinhamento tem como resultado uma ou mais regiões conservadas entre as seqüências.

O alinhamento global é frequentemente utilizado para determinar regiões mais conservadas de seqüências homólogas. Os programas que utilizam este tipo de alinhamentos são o ClustalW e Multialin. O alinhamento local é geralmente utilizado na procura por seqüências homólogas ou análogas em bancos de dados. O algoritmo utilizado pelo programa BLAST realiza este tipo de alinhamento.

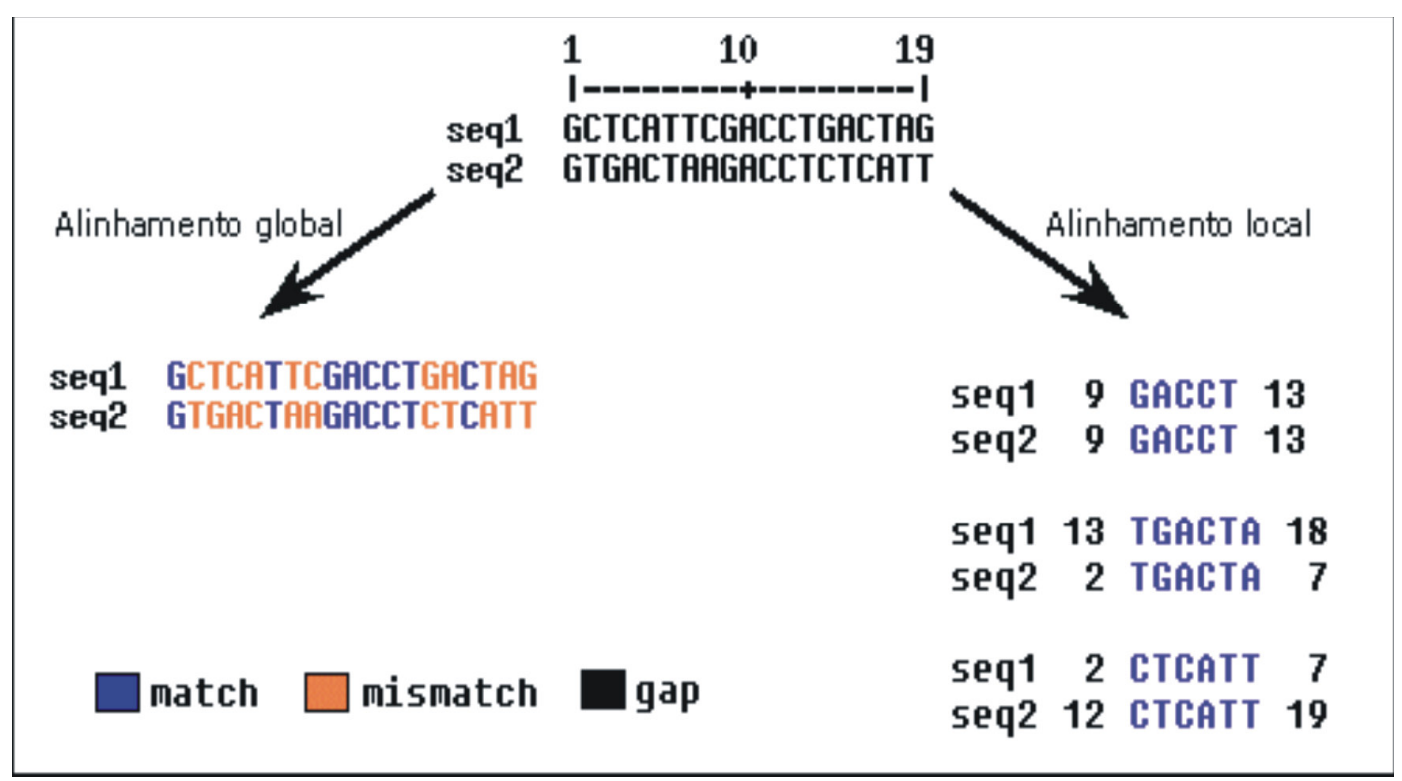

Figura 4.1: Diagrama dos alinhamentos de seqüências local e global. 


\subsection{OBJETIVOS}

> Classificar e estudar a similaridade genética das bactérias isoladas com dados obtidos da RAPD-PCR em microchips, utilizando técnicas de bioinformática.

> Caracterizar molecularmente as diversas cepas isoladas de Alicyclobacillus a partir de sucos de frutos ácidos, por meio do seqüenciamento do gene $16 S$ rRNA.

Analisar as seqüências obtidas do gene 16S rRNA e estimar a posição filogenética das cepas isoladas utilizando programas de bioinformática.

\subsection{MATERIAIS E MÉTODOS}

\subsubsection{Análise de polimorfismos de RAPD das cepas isoladas}

Para as análises de polimorfismos de RAPD produzidas pelas cepas isoladas, foram calculadas as estimativas das distâncias genéticas. Os fragmentos visualizados nos eletroferogramas foram determinados no equipamento Bioanalyzer 2100. A partir dos dados obtidos, foram construídas matrizes de caracteres discretos, isto é, com algarismos 0 e 1 representando, respectivamente, a ausência ou a presença de determinado fragmento. A partir dessas matrizes, foi feito o cálculo (algoritmo baseado em Jaccard) de uma matriz de distância genética entre os isolados, utilizando-se o programa DNAdist. Com o programa PHYLIP v.3.66, foram construídos diagramas representando o agrupamento dos isolados em estudo, pelo método UPGMA. Esses diagramas são modos de visualização mais rápido e prático dos agrupamentos do que a análise das matrizes de distância. As amostras de cepas isoladas estão descritas e codificadas na Tabela 3.1, no Capítulo 3. 


\subsubsection{Construção da árvore de consenso para o polimorfismo de RAPD}

Para verificar a consistência dos dendogramas gerados para os cinco primers construiu-se uma árvore de consenso com a técnica bootstrap que consiste na reamostragem das matrizes originais para formação de uma nova matriz baseada na combinação de todos os primers. Foram gerados 31 dendogramas conforme a equação $2^{n}-1$, sendo $n$ o número de primers, que são cinco. $O$ dendograma consenso representa quais os agrupamentos mais freqüentes dentre os dendogramas obtidos por bootstrap.

\subsubsection{Amostragem de cepas de sucos de frutos ácidos}

Para a análise filogenética a partir do seqüenciamento do gene 16S rRNA (294 bp), foram escolhidas 11 cepas que geraram maior variação filogenética segundo os resultados obtidos nos RAPD-PCR descritos no Capítulo 3. Na Tabela 4.1 são descritas as amostras utilizadas no experimento. 
Tabela 4.1: Amostras controle e cepas isoladas de diferentes sucos de frutas, escolhidas para o seqüenciamento do gene 16S rRNA pertencente ao gênero Alicyclobacillus spp.

\begin{tabular}{|l|c|}
\hline \multicolumn{1}{|c|}{ Amostra/Suco } & Código \\
\hline Alicyclobacillus acidoterrestris CCT $=4384$ & $\mathrm{C}+2$ \\
\hline Alicyclobacillus acidoterrestris (Cargill - Japão) & $\mathrm{C}+5$ \\
\hline Concentrado de laranja Nutricitrus & 2 \\
\hline Diluído de maracujá da Fruta & 4 \\
\hline Diluído de abacaxi Milani 1 & 14 \\
\hline Diluído de abacaxi da Fruta 1 & 16 \\
\hline Superfície de frutos de laranja & $\mathrm{Lfr}$ \\
\hline Concentrado de limão Limonjal & $\mathrm{lim}$ \\
\hline Superfície de laranjas do pomar/solo & $\mathrm{T} 1$ \\
\hline Suco de laranja in natura da rua 1 & $\mathrm{T} 2$ \\
\hline Superfície de laranjas do pomar/meio & $\mathrm{T} 4$ \\
\hline
\end{tabular}

\subsubsection{Reações de seqüenciamento}

O fragmento de 294 pares de base contendo a região do gene 16S rRNA foi submetido para reações de seqüenciamento de DNA. Primeiramente, os produtos de PCR foram purificados com o kit SV gel PCR clean-up System (Promega ${ }^{\mathrm{TM}}$ ) e depois quantificados com o kit LabChip 1000 no Bioanalyzer 2100 (Agilent Technologies) de acordo com as instruções do fabricante e submetido ao seqüenciamento de DNA em seqüenciador automático $\mathrm{ABI} 3100$ (Applied Biosystems ${ }^{\mathrm{TM}}$ ), análises gentilmente realizadas pelo laboratório de Biotecnologia Animal da CPPSE-EMBRAPA. 
A reação de seqüenciamento consistiu em $2 \mu \mathrm{L}$ de BigDye 3 (Applied Byosystems $^{\mathrm{TM}}$ ), $2 \mu \mathrm{L}$ de tampão Save Money $5 \times, 2$ pmol do primer antisense e $8 \mathrm{ng}$ do amplicon purificado, para uma reação de $10 \mu \mathrm{L}$. A reação de seqüenciamento foi amplificada no termociclador PTC-100 (MJ Research $\left.{ }^{\mathrm{TM}}\right)$ com desnaturação previa de $94{ }^{\circ} \mathrm{C} / 2$ min e 25 ciclos de $96{ }^{\circ} \mathrm{C} / 20 \mathrm{~s}, 55^{\circ} \mathrm{C} / 15$ s e $60^{\circ} \mathrm{C} / 4$ min. A seguir o produto desta reação foi precipitado à temperatura ambiente com $40 \mu \mathrm{L}$ de isopropanol a $75 \%$, incubado por $15 \mathrm{~min}$, centrifugado a $14000 \times \mathrm{g} / 25 \mathrm{~min}$ e removendo-se o sobrenadante. Depois, foi adicionado $200 \mu \mathrm{L}$ de etanol a $60 \%$, centrifugado a $14000 \times \mathrm{g} / 5$ min e finalmente, deixou-se secando o precipitado. Antes de realizar as corridas eletroforéticas de seqüenciamento, o pellet foi diluído com formamida e desnaturado a $95{ }^{\circ} \mathrm{C} / 5 \mathrm{~min}$ e depois incubado a $4{ }^{\circ} \mathrm{C} / 3 \mathrm{~min}$. O alinhamento e análises das seqüências obtidas foram realizados com o ClustalW e o programa Mega 3.1 para a construção da árvore filogenética.

\subsubsection{Análise filogenética de seqüenciamento}

Um alinhamento se seqüências foi utilizado para analisar os resultados obtidos neste estudo. Este método de comparação procura determinar o grau de similaridade entre duas ou mais seqüências, ou a similaridade entre fragmentos destas seqüências. Existem vários programas que realizam esta tarefa e a grande maioria deles pode ser utilizado on-line. Os resultados de seqüenciamento foram confirmados pelo programa BLAST (Basic Local Alignment Search Tool - NCBI), que procurou as seqüências homólogas no GenBank e depois foram alinhadas com o programa ClustalW. 
A árvore filogenética para o gene 16S rRNA foi construída com as seqüências consensuais de cada amostra alinhadas no programa ClustalW. Utilizando as seqüências alinhadas de Alicyclobacillus spp. (Tabela 4.1), obtiveram-se as árvores filogenéticas utilizando o método de distância neighbor joining, e o nível de consenso da topologia da árvore filogenética foi avaliada 1000× pelo método de bootstrap (Felsenstein, 1985). O software para a construção da árvore filogenética e análise do bootstrap foi o programa Mega 3.1.

\subsection{RESULTADOS E DISCUSSÕES}

\subsubsection{Análises filogenéticas com RAPD-PCR}

Com a matriz de dados binários, obtida a partir dos fragmentos de DNA amplificados com cada primer, foram geradas cinco dendogramas correspondentes aos primers P4, P5, E2, E15 e E16. Os cinco dendogramas foram analisados em função da melhor distribuição das cepas isoladas, com coeficientes de similaridades próximos a $100 \%$. Considerando este aspecto, os primers escolhidos para avaliar as análises filogenéticas foram o E2 e o E15.

No dendograma obtido com o primer OP-E2 foi realizado um corte arbitrário de $65 \%$ de similaridade, observando-se quatro agrupamentos principais das cepas de Alicyclobacillus analisadas. O primeiro grupo é composto pelas cepas $\mathrm{C} 1, \mathrm{C} 2$, que apresentaram $100 \%$ de similaridade, e as cepas T3, lim e C3, com coeficientes de similaridade que variaram entre 66 e $83 \%$, onde observamos que as cepas de suco concentrado de limão e suco in natura de laranja apresentaram maior similaridade a $A$. acidoterrestris. O segundo agrupamento mostra a distribuição da cepa do controle C4 (A. cicloheptanicus), que foi similar em $63 \%$, com respeito ao 
primeiro agrupamento. O terceiro agrupamento abrange a maior parte das amostras, as quais apresentaram coeficientes de similaridade entre 68 e 95\%. Dentre deste grupo observamos a presença de 3 subgrupos, os quais tiveram a maior similaridade com o controle C5 (cepa obtida do Japão), e as cepas correspondentes aos sucos diluídos e concentrados de laranja, suco concentrado de maracujás e a cepa de superfície de limões respectivamente. Neste agrupamento observamos que a cepa de superfície de limões (Lim) teve uma menor similaridade de $67 \%$ com respeito às outras cepas deste terceiro agrupamento. Finalmente, o quarto grupo contém a amostra 16 (suco diluído de abacaxi), que apresenta um menor coeficiente de similaridade de 55\% com respeito às demais cepas isoladas (Figura 4.2).

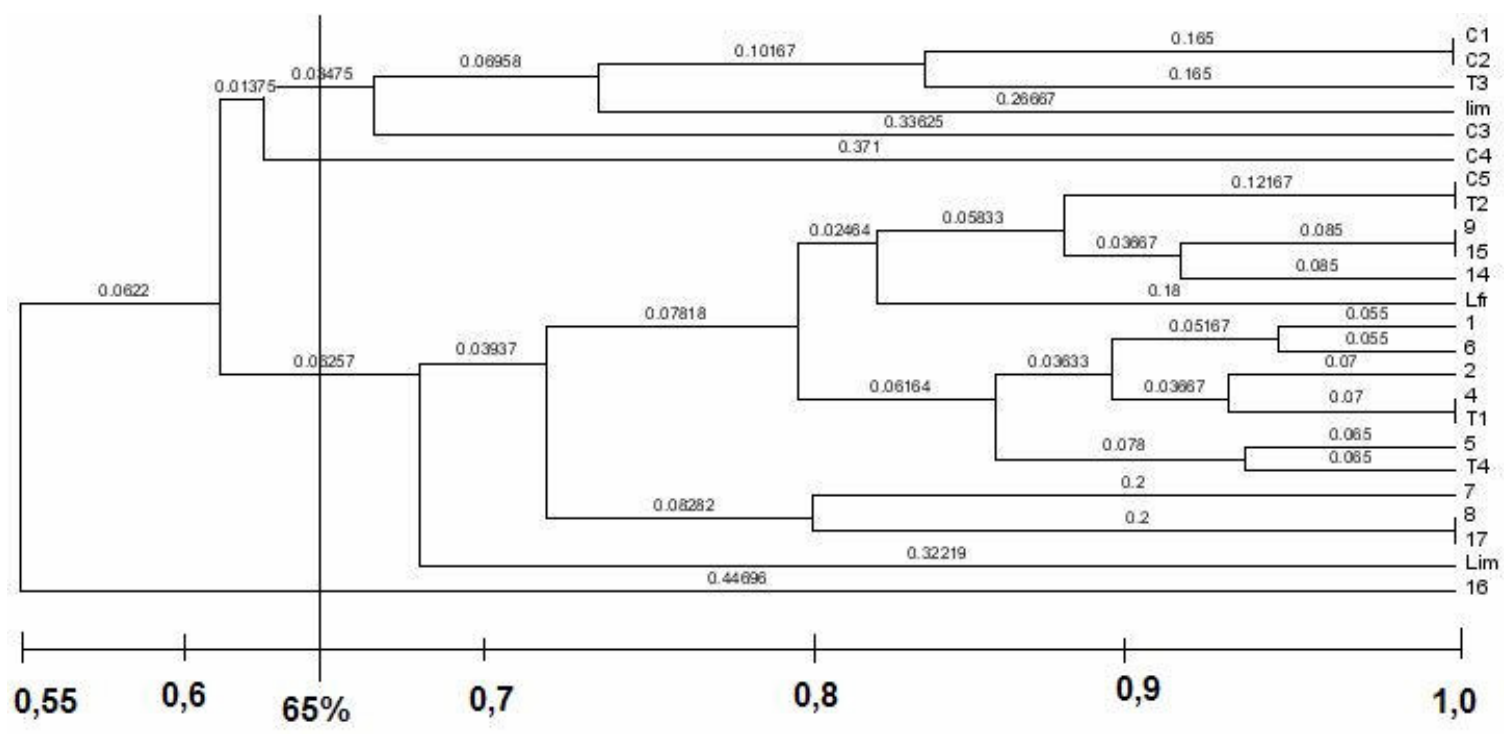

Figura 4.2: Árvore filogenética com coeficientes de similaridade, obtida com o primer OP-E2. A identificação completa das cepas encontra-se na Tabela 3.1 do Capítulo 3.

No dendograma obtido com o primer E15 (Figura 4.3), também foi realizado um corte arbitrário de $65 \%$ de similaridade, observando-se a distribuição de quatro agrupamentos. No primeiro agrupamento obtemos um coeficiente de similaridade de 75\% entre as amostras do controle C1 e cepa obtida de suco concentrado de 
maracujá (8). No segundo agrupamento, observamos nove cepas agrupadas com similaridades entre $73 \%$ e $83,5 \%$. Este agrupamento incluiu dois subgrupos distribuídos como: C5, 1, 4, 9, T4, 2, 5, e superfície de limões e laranjas, sendo que, estas últimas três amostras tiveram similaridade de $75 \%$ com respeito ao outro subgrupo. No terceiro agrupamento apresentaram 6 cepas com similaridades entre $71 \%$ e $87 \%$, este grupo inclui o controle C4 (A. cycloheptanicus), 15, T1, 14, 16, e a cepa do suco concentrado de limão. O quarto agrupamento das cepas 6, T3, T2 tiveram similaridades entre 70 e $83 \%$, mas tiveram menor similaridade de $54 \%$ com respeito às demais cepas.

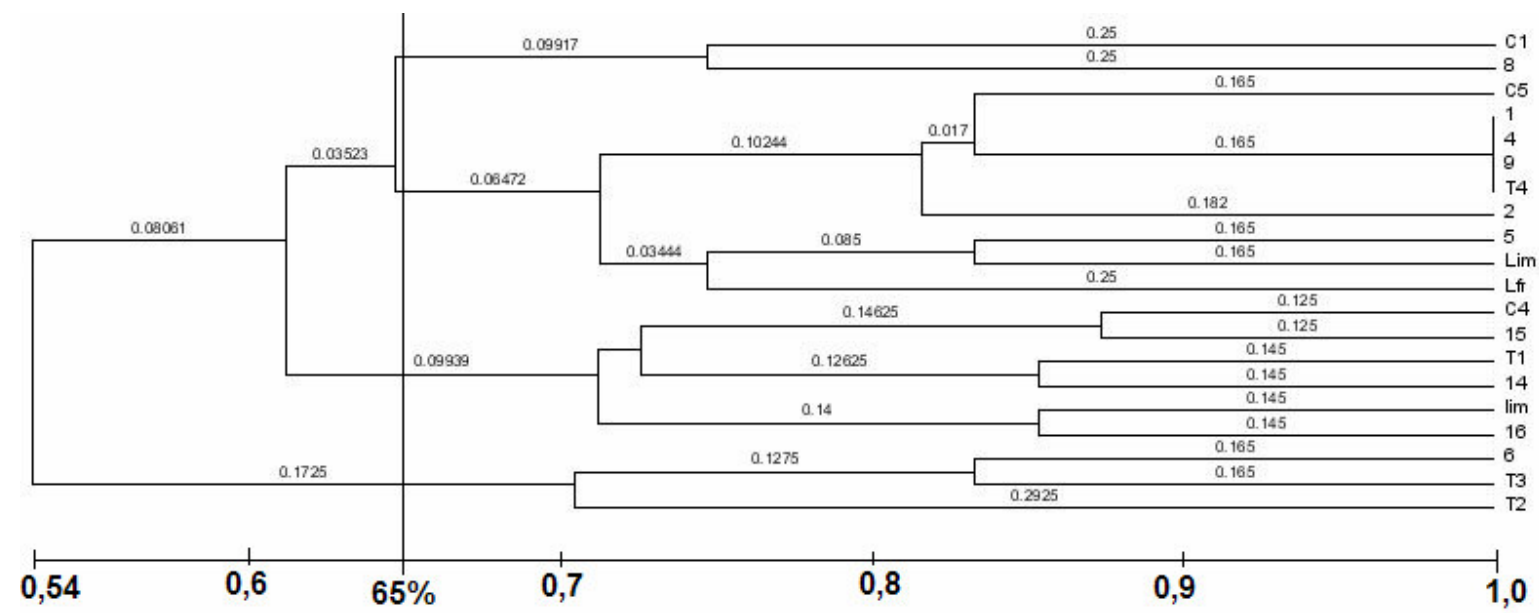

Figura 4.3: Árvore filogenética com coeficientes de similaridade, obtida com o primer E15. A identificação completa das cepas encontra-se no Capítulo 3, Tabela 3.1.

A árvore de consenso mostra a distribuição das 24 cepas com os primers $P 4$, P5, E2, E15 e E16, obtida com base no suporte de bootstrap. Na Figura 4.4, observa-se um dendograma pouco definido devido ao fato da freqüência de análise ser baixa, apenas 31 repetições. Aumentando-se o número de primers nas análises de RAPD para as cepas isoladas, possivelmente teríamos uma melhor definição dos agrupamentos. É válido ressaltar que a árvore de consenso não representa a 
filogenia dos organismos, ela apenas indica o quão boa é a filogenia obtida pelo conjunto de dados original.

Os números dispostos em cada ramo desta árvore significam a freqüência na qual cada agrupamento permaneceu junto durante todas as análises, por exemplo, as cepas Lfr e lim conservaram-se unidas em 100\% das análises realizadas, pois das 31 combinações dos parâmetros (primers) realizadas em todas elas permaneceram próximas. Pode-se deduzir, portanto, que essas cepas têm grande similaridade, como comprova a Figura 4.4 que mostra uma similaridade de $98,8 \%$.

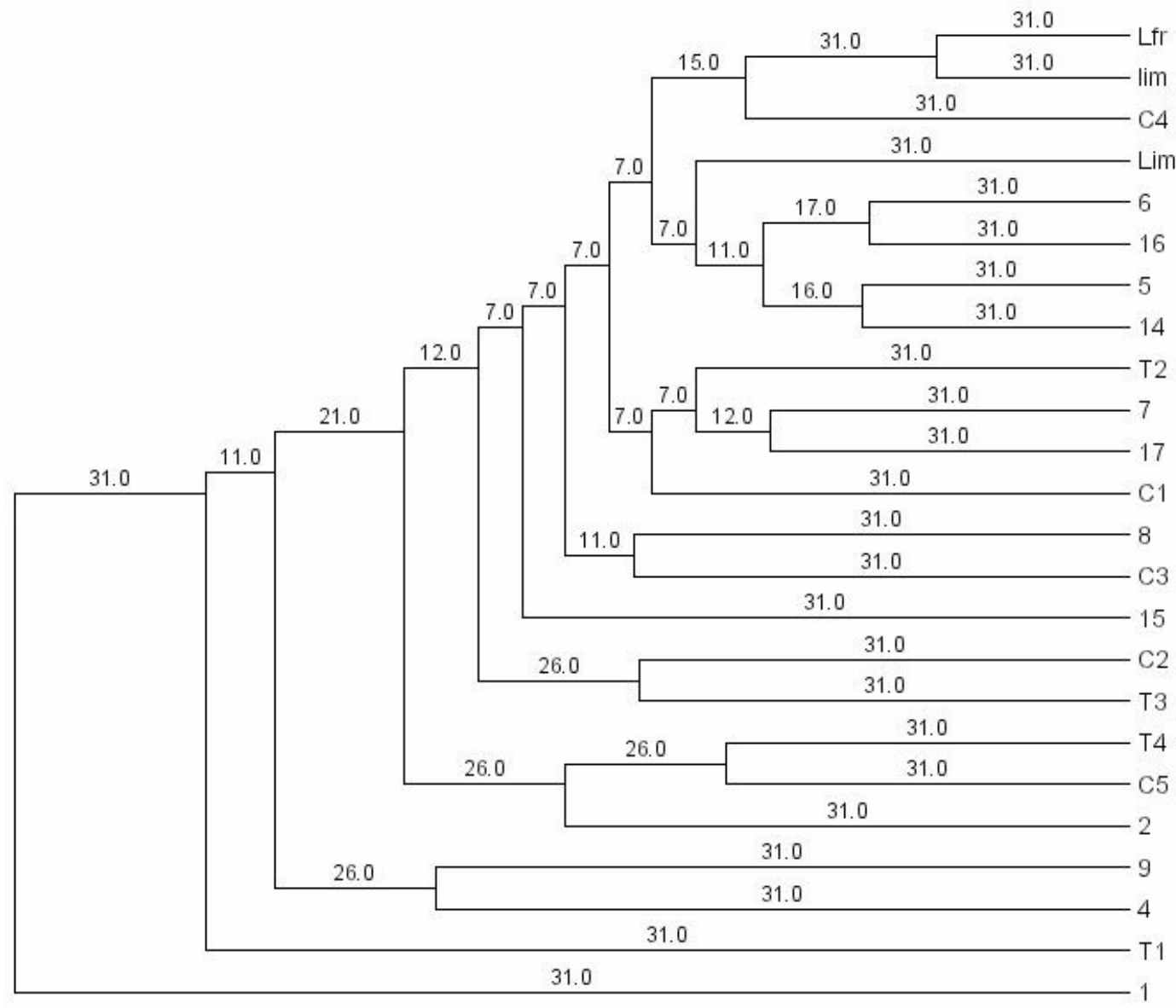

Figura 4.4: Árvore de consenso obtida com base no suporte de bootstrap com os dados originais dos cinco primers utilizados.

Contudo, pode-se ainda avaliar algumas concordâncias nesta árvore de consenso, como por exemplo, a similaridade entre as cepas 2, C5 e T4 agrupadas 
em um cluster. Há ainda as cepas Lfr, lim, C4, Lim, 6, 16, 5, 14 que se mostram próximas entre si e agrupadas em um grande cluster. As cepas correspondentes aos sucos de maracujá diluído (4) e tangerina concentrada (9) formaram um grupo definido e com baixa similaridade com as outras cepas. No caso das cepas de suco concentrado de laranja (1) e cepa de laranjas de pomar (T1), mantiveram-se sempre isoladas com as 31 combinações de bootstrap, e com baixas similaridades com respeito às demais cepas. A única amostra que teve boa similaridade com respeito ao controle C3 ( $A$. acidocaldarius) foi com a cepa de suco de maracujá concentrado (8).

Considerando os dois controles $\mathrm{C} 1$ e C2, da espécie A. acidoterrestris, formaram dois clusters diferentes, onde o controle $\mathrm{C} 1$ agrupou às cepas de suco in natura da rua (T2), suco de abacaxi (17) e superfície de maracujás (7); e o controle C2 agrupou também a uma amostra de suco in natura da rua (T3) obtendo-se boas similaridades com respeito às combinações de bootstrap. Contudo, podemos concluir que mesmo apesar dos controles $\mathrm{C} 1$ e $\mathrm{C} 2$ estarem dispersos na árvore elas apresentaram a mesma similaridade com a cepa de suco in natura, o que indica que os frutos de laranja estariam sendo mal manipulados na hora da lavagem do fruto.

\subsubsection{Análise de seqüenciamento}

As amostras utilizadas nas análises de seqüenciamento foram escolhidas segundo aquelas que tiveram menor grau de similaridade nas reações de RAPD-

PCR. As análises filogenéticas, baseadas no seqüenciamento do gene 16S rRNA (294 bp), foram seqüenciadas e depois alinhadas com as seqüências publicadas no banco de dados NCBI, com a ferramenta BLAST. Na Tabela 4.2 apresentamos a identificação das cepas isoladas segundo o tipo de microrganismo, porcentagem de 
similaridade e número de aceso da bactéria, estas informações foram obtidas do banco de dados NCBI. Todas as cepas isoladas foram identificadas como Alicyclobacillus acidoterrestris, com identidades entre 97 e 99\%. Para a construção das árvores filogenéticas, foram incluídas cinco seqüências de diferentes linhagens, escolhidas do banco de dados (NCBI): $A$. acidocaldarius, $A$. cycloheptanicus, $A$. acidiphilus, $A$. sendaiensis e Sulfobacillus acidophilus. Estas amostras apresentaram identidades de $100 \%$ por serem amostras controle para comparação nos alinhamentos múltiplos e construção da árvore filogenética. 
Tabela 4.2: Informação das seqüências alinhadas a partir das cepas isoladas em sucos e frutas ácidas.

\begin{tabular}{|c|c|c|c|c|}
\hline Amostra & Microrganismo & \# acesso & $\begin{array}{c}\% \\
\text { identidade }\end{array}$ & Referência \\
\hline 14 & $\begin{array}{l}\text { Alicyclobacillus } \\
\text { acidoterrestris }\end{array}$ & AB042058.1 & 99 & $\begin{array}{l}\text { Goto, K. et } \\
\text { al(2002) }\end{array}$ \\
\hline 16 & $\begin{array}{l}\text { Alicyclobacillus } \\
\text { acidoterrestris }\end{array}$ & EF095718.1 & 98 & $\begin{array}{l}\text { Chen,X.et al (não } \\
\text { publicado) }\end{array}$ \\
\hline 2 & $\begin{array}{l}\text { Alicyclobacillus } \\
\text { acidoterrestris }\end{array}$ & AB059676.1 & 98 & $\begin{array}{l}\text { Goto, K. et al } \\
\text { (não publicado) }\end{array}$ \\
\hline 4 & $\begin{array}{l}\text { Alicyclobacillus } \\
\text { acidoterrestris }\end{array}$ & AB042057.1 & 98 & $\begin{array}{l}\text { Goto, K. et } \\
\text { al(2002) }\end{array}$ \\
\hline $\mathrm{C} 2$ & $\begin{array}{l}\text { Alicyclobacillus } \\
\text { acidoterrestris }\end{array}$ & AB059675.1 & 97 & $\begin{array}{l}\text { Goto, K. et al } \\
\text { (não publicado) }\end{array}$ \\
\hline C5 & $\begin{array}{l}\text { Alicyclobacillus } \\
\text { acidoterrestris }\end{array}$ & AB042058.1 & 97 & $\begin{array}{l}\text { Goto, K. et } \\
\text { al(2002) }\end{array}$ \\
\hline Lfr & $\begin{array}{l}\text { Alicyclobacillus } \\
\text { acidoterrestris }\end{array}$ & AB042058.1 & 97 & $\begin{array}{l}\text { Goto, K. et } \\
\text { al(2002) }\end{array}$ \\
\hline $\lim$ & $\begin{array}{l}\text { Alicyclobacillus } \\
\text { acidoterrestris }\end{array}$ & AY686619.1 & 98 & $\begin{array}{l}\text { Rodrigues, D.C. } \\
\text { et al. (2005) }\end{array}$ \\
\hline T4 & $\begin{array}{l}\text { Alicyclobacillus } \\
\text { acidoterrestris }\end{array}$ & AJ544223.2 & 97 & $\begin{array}{l}\text { Connor, C.J. et al. } \\
\text { (2005) }\end{array}$ \\
\hline T2 & $\begin{array}{l}\text { Alicyclobacillus } \\
\text { acidoterrestris }\end{array}$ & AB042058.1 & 99 & $\begin{array}{l}\text { Goto, K. et } \\
\text { al(2002) }\end{array}$ \\
\hline T1 & $\begin{array}{l}\text { Alicyclobacillus } \\
\text { acidoterrestris }\end{array}$ & EF095718.1 & 99 & $\begin{array}{l}\text { Chen,X.et al (não } \\
\text { publicado) }\end{array}$ \\
\hline Controle 3 & $\begin{array}{l}\text { Alicyclobacillus } \\
\text { acidocaldarius }\end{array}$ & AY573796.1 & 100 & $\begin{array}{l}\text { Connor, C.J. et al. } \\
\text { (2005) }\end{array}$ \\
\hline Controle 4 & $\begin{array}{l}\text { Alicyclobacillus } \\
\text { cycloheptánicus }\end{array}$ & AY573798.1 & 100 & $\begin{array}{l}\text { Connor, C.J. et al. } \\
\text { (2005) }\end{array}$ \\
\hline Controle 6 & $\begin{array}{l}\text { Alicyclobacillus } \\
\text { acidiphilus }\end{array}$ & AB076660.1 & 100 & $\begin{array}{l}\text { Matsubara,H. et } \\
\text { al. (2002) }\end{array}$ \\
\hline Controle 7 & Sulfobacillus acidophilus & AB089842 & 100 & $\begin{array}{l}\text { Goto, K. et } \\
\text { al(2003) }\end{array}$ \\
\hline Controle 8 & $\begin{array}{l}\text { Alicyclobacillus } \\
\text { sendaiensis }\end{array}$ & AB084128 & 100 & $\begin{array}{l}\text { Nishino, T. et al } \\
\text { (2003) }\end{array}$ \\
\hline
\end{tabular}

O alinhamento múltiplo e construção das árvores filogenéticas foram geradas com os programas ClustalW e o método neighbor joining respectivamente. Estas análises foram suportadas com análises de bootstrap com repetições de 1000x. A árvore filogenética gerada indica a posição das cepas isoladas com respeito aos controles do gênero Alicyclobacillus spp. e Sulfobacillus acidophilus. 
Na Figura 4.5, obtemos uma árvore filogenética dividida em três clusters. No primeiro cluster observamos que as onze cepas analisadas e o controle C2 ( $A$. acidoterrestris), tiveram um valor alto de bootstrap, com similaridade nas seqüências de $99 \%$, isto indica, que as cepas analisadas podem ser agrupadas dentro da espécie $A$. acidoterrestris. Neste cluster, observam-se também, dois subgrupos bem definidos, onde o controle C2 ( $A$. acidoterrestris) e a cepa de suco concentrado de limão tiveram similaridades de $63 \%$, também observamos que o controle C5 abrangeu a maior quantidade de cepas com porcentagens de similaridades de $65 \%$. No entanto, estes dois subgrupos apresentaram similaridades de seqüências de $99 \%$ entre todas elas. Neste subgrupo se observa claramente como a cepa de superfície de laranja ( $(\mathrm{fr})$ e a cepa de suco diluído de maracujá (4), se mantiveram agrupadas com menor similaridade de $11 \%$ com respeito à cepa isolada de Japão (C5) o que indica uma distribuição diferenciada entre cepas de superfície de laranja (Lfr), suco de maracujá (4), abacaxi (14 e 16), laranjas (T2 e 2) e de laranjas de pomares (T4).

Um segundo cluster é observado unicamente com a cepa de A. acidiphilus, que inclui boa similaridade com respeito às cepas isoladas no primeiro cluster. No terceiro cluster, as amostras controles, pertencentes a outras espécies e gêneros, mantiveram entre 94 e $99 \%$ de similaridade entre os controles das espécies $A$. acidocaldarius, A. cicloheptanicus, $A$. sendaiensis e Sulfobacillus acidophilus, o que permitiu uma discriminação entre as cepas isoladas e os controles de outras espécies e gêneros. 


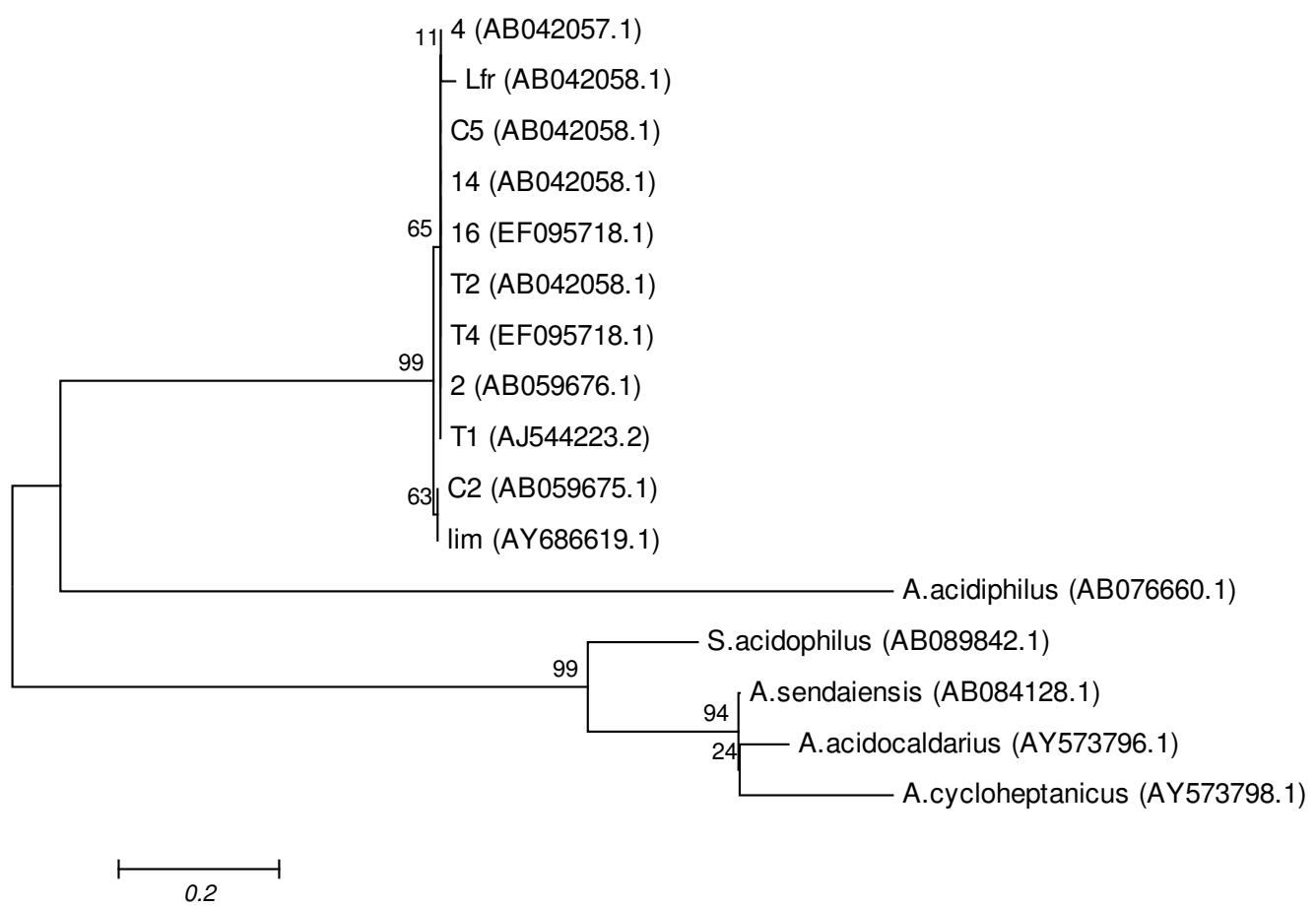

Figura 4.5: Árvore filogenética, utilizando os métodos neighbor joining e bootstrap 1000x, mostrando a posição filogenética das cepas obtidas de sucos e frutos ácidos, baseados nas seqüências do $16 \mathrm{~S}$ rRNA.

\subsection{CONCLUSÕES}

As análises de RAPD-PCR foram avaliadas com cinco primers, obtendo-se cinco dendogramas diferentes com similaridades que variaram entre 60 e $100 \%$. Devido à inconsistência nestes dendogramas, os dados foram analisados com a técnica bootstrap. A árvore de consenso gerada representou maior freqüência no agrupamento das cepas de laranjas do pomar/solo e concentrados de laranja (T4 e 2) com a cepa isolada do Japão (C5), também que os controles $\mathrm{C} 1$ e $\mathrm{C} 2$ de $A$. acidoterrestris se agruparam com a mesma freqüência com os sucos in natura de laranja (T2 e T3) comprados no comércio local. As cepas de suco diluído de maracujá (4), concentrado de tangerina (9) e superfície de laranja do pomar (Lfr), foram aquelas que se mantiveram com menor similaridade e menor freqüência no 
agrupamento com respeito às demais cepas. A grande variabilidade evidenciada entre as cepas na árvore de consenso, está associada ao fato da reação de RAPDPCR utilizar informações do DNA genômico e não de regiões específicas, como as que são utilizadas em análises de seqüenciamento.

O estudo de análise filogenética baseada em seqüências de DNA da região variável do gene $16 \mathrm{~S}$ rRNA de Alicyclobacillus acidoterrestris foi utilizado para identificar e agrupar onze cepas isoladas de superfícies e sucos de frutos ácidos. Os resultados revelaram que estas cepas podem ser categorizadas dentro da espécie Alicyclobacillus acidoterrestris. Na árvore filogenética gerada pelo método neighbor joining e bootstrap 1000x, as cepas analisadas mostraram similaridades de $99 \%$ entre todas elas, observando-se uma maior similaridade do controle $A$. acidoterretris (C2) com a cepa isolada de suco concentrado de limão (lim), e uma boa discriminação entre controles das espécies $A$. acidocaldarius, $A$. cicloheptanicus, $A$. sendaiensis e Sulfobacillus acidophilus.

A região variável do gene $16 \mathrm{~S}$ rRNA de $A$. acidoterrestris (294 bp) foi facilmente seqüenciada com as amostras das cepas analisadas, o que indica que pode ser aplicado para investigar a composição ou distribuição de espécies e, até o reconhecimento e classificação de uma nova espécie de $A$. acidoterrestris que porventura possa vir a ser isolada no prosseguimento desta pesquisa. 


\section{REFERÊNCIAS BIBLIOGRÁFICAS}

ALBUQUERQUE, L.; RAINEY, F.A.; CHUNG, A.P.; SUNNA, A; NOBRE, M.F.; GROTE, R.; ANTRANIKIAN, G.; DA COSTA, M.S. Alicyclobacillus hesperidium sp. Nov. and a related genomic species from solfataric soils of São Miguel in the Azores. International Journal of Systematic and Evolutionary Microbiology, v. 51, p. 451-457, 2000.

ATKINS S.D.; CLARK I.M. Fungal molecular diagnostics: a mini review. Journal Applied Genetic, v. 45, n. 1, p. 3-15, 2004.

BELO, H.E. Uma resposta bayesiana ao paradoxo de Suzuki. 2005. $83 \mathrm{f}$. Dissertação (Mestrado em Estatística) - Instituto de Matemática, Universidade Federal de Rio de Janeiro, Rio de Janeiro, 2005.

BORLINGHAUS, A.; ENGEL, R. Alicyclobacillus incidence in commercial apple juice concentrate (AJC): supplies, method development and validation. Fruit Processing, v. 7, p. $1-5,1997$.

BOXER, M. Molecular techniques: divide or share. Journal and Clinical Pathology, v. 53, n. 1, p. 19-21, 2000.

BROWN, K.L. New biological spoilage challenges in aseptics: Alicyclobacillus acidoterrestris spoilage in aseptically packed fruit juices. In: INTERNATIONAL SYMPOSIUM OF PROCESSING, n. 10; 1995, Copenhagen. Proceedings on Advances in aseptic processing and packaging technologies. Copenhagen: Ohlsson T., 1995. v. 12, p. 1-14.

BUSO, G.S.C. Marcadores Moleculares e Análise Filogenética. Brasília: Ed. Embrapa Recursos Genéticos e Biotecnologia, 2005. p. 45.

BUSTIN, S. A. Absolute quantification of mRNA using real-time reverse transcription polymerase chain reaction assays. Journal of Molecular Endocrinology, v. 25, p. 169-193, 2000.

CARUSO, C.S.; LANÇAS, F.M.; CARRILHO, E. Multiplexed DNA sizing by capillary electrophoresis using entangled polymer solutions and diode array detection.

Electrophoresis, v. 24, n. 1-2, p. 78-85, 2003.

CERNY, G.; DUONG, H.A.; HENNLICH, W.; MILLER, S. Alicyclobacillus acidoterrestris: influence of oxygen content on growth in fruit juices. Food Australia, v. 52, p. 289, 2000.

CERNY, G.; HENNLICH, W.; PORALLA, K. frutchtsaftverderb durch Bacillen: Isolerung und Charakterisierung des Verderserrgers. Lebens Unters Forsch, v. 179, p. 244-227, 1984. 
CHANG, S.; KANG, D.H. Alicyclobacillus spp. in the Fruit Juice Industry: History, Characteristics, and Current Isolation/Detection Procedures. Critical Reviews in Microbiology, v. 30, p. 55-74, 2004.

CLARRIDGE, J.E. Impact of 16 S rRNA Gene sequence analysis for identification of bacteria on clinical microbiology and infectious diseases. Clinical Microbiology Reviews, v.12, p. 840-862, 2004.

DE ROSA, M.; GANBACORTA, A.; BULOCK, J.D. Effects of pH and temperature on the fatty acid composition of Bacillus acidocaldarius. Journal of Bacteriology, $v$. 117, p. 212-214, 1974.

DEINHARD, G.; SAAR, J.; KRISCHKE, W.; PORALLA, K. Bacillus cycloheptanicus $s p$. nov., a new thermoacidophile containing $\omega$-cycloheptane fatty acids. Systematic Applied Microbiology, v. 10, p. 68-73, 1987.

DOOLEY, J.J.; SAGE H.D.; BROWN, H.M.; CLARKE, M.A.L.; GARRETT, S.D. Fish Species identification using PCR-RFLP analysis and Lab-on-a-Chip Capillary Electrophoresis: Application to detect white fish species in food products and an interlaboratory study. Journal Agriculture Food Chemistry, v. 53, p. 3348-3357, 2005.

DOORES, S. The microbiology of apples and apple products. Critical Reviews Food Sciences, v. 19, p. 133, 1983.

EGUCHI, S.Y.; MANFIO, G.P.; PINHATTI, M.E.; AZUMA, E.; VARIANE, S.F. Acidothermophilic sporoforming bacteria (ATSB) in Orange Juices: detection methods, ecology and involvement in the deterioration of fruit juices. Campinas: Fundação André Tosello \& ABECITRUS, 1999. p. 52 (Report of Research Project of the Coleção de Culturas Tropicais).

FARBER, J.M. An introduction to the hows and whys of molecular typing. Journal Food Protection. v. 59, n. 10, p. 1091-1101, 1996.

FELSENSTEIN, J. Confidence limits on phylogenies: an approach using the bootstrap. Evolution, v. 2, p. 783-791, 1985.

FUNES-HUACCA, M.E.; REGITANO, L.C.A.; MUELLER, O.; CARRILHO, E. Semiquantitative determination of Alicyclobacillus acidoterrestris in orange juice by reverse-transcriptase polymerase chain reaction and capillary electrophoresis - laser induced fluorescence using microchip technology. Electrophoresis, v. 25, p. 38603864, 2004.

FUNGARO, M.H.P. PCR na micologia. Biotecnologia: Ciência \& Desenvolvimento, v. 3, p. 12-16, 2000.

GOTO, K.; MATSUBARA, H.; MOCHIDA, K.; MATSUMURA, T.; HARA, Y.; NIWA, M.; YAMASATO, K. Alicyclobacillus herbarius sp. nov., a novel bacterium containing $\omega$-cycloheptane fatty acids, isolated from herbal tea. International Journal

Systematic Evolution Microbiology, v. 52, p. 109-113, 2002. 
GOTO, K.; TANIMOTO, Y.; TAMURA, T.; MOCHIDA, K. Identification of thermoacidophilic bacteria and a new Alicyclobacillus genomic species isolated from acidic environments in Japan. Extremophiles, v. 6, p. 333-340, 2002.

GRANDE, M.J.; LUCAS, R.; ABRIOUEL, H.; BEN OMAR, N.; MAQUEDA, M.; MARTÍNEZ-BUENO, M.; MARTíNEZ-CAÑAMERO, M.; VALDIVIA, E., GÁLVEZ, A. Control of Alicyclobacillus acidoterrestris in fruit juices by enterocin AS-48. International Journal of Food Microbiology, v. 104, p. 289-297, 2005.

GRAY, M.W.; SANKOFF, D.; CEDERGREN, R.J. On the evolutionary descent of organisms and organelles: a global phylogeny based on a highly conserved structural core in small subunit ribosomal RNA. Nucleic Acid Research, v. 12, p. 5837-5852, 1984.

HOSTETTMANN, K.; MARSTON, A. Saponins Chemistry \& Pharmacology of Natural Products. Cambridge: Cambridge University, 1995, p. 82-91.

JAY, J.M. Modern food microbiology. 6. ed. Gaithersburg: Aspen Publishers, 2000, p. 38.

JENSEN, N.; WHITFIELD, F.B. Role of Alicyclobacillus acidoterrestris in the development of a disinfectant taint in shelf-stable fruit juice. Letter and Applied Microbiology, v. 36, p. 9-12, 2003.

KANNERNBERG, E.; BLUME, A.; PORALLA, K. Properties of $\omega$-cyclohexane fatty acids in membranes. FEBS, v. 172, n. 2, p. 331-334, 1984.

KHANDURINA, J.; GUTTMAN, A. Bioanalysis in microfluidic devices. Journal of Chromatography A, v. 943, p. 159-183, 2002.

KNUTSSON, R.; BLIXT, Y.; GRAGE, H.; BORCH, E.; RADSTROM, P. Evaluation of selective enrichment PCR procedures for Yersinia enterocolitica. International Journal Food Microbiology, v. 73, p. 35-46, 2002.

KOMITOPOULOU, E.; BOZIARIS, I.S.; DAVIES, E.A.; DELVES-BROUGHTON, J.; ADAMS, M.R. Alicyclobacillus acidoterrestris in fruit juices and its control by nisin. International Journal Food Sciences Technologies, v. 34, p. 81-86, 1999.

LANTZ, P.G.; AI SOUD, W.A.; KNUTSSON, R.; HAHN-HAGERDAL, B.; RADSTROM, $P$. Biochemical use of polymerase chain reaction for microbiological analysis of biological samples. Biotechnology Annual Review, v. 5, p. 87-130, 2000

LEMOS, T.L.G.; MENDES, A.L.; SOUSA, M.P. New saponin from Sapindus saponaria. Fitoterapia, v. 63, n. 6, p. 515-517, 1992.

LI, W.; DRAKE, M.A. Development of a quantitative competitive PCR assay for detection and quantification of Escherichia coli O157:H7 cells. Applied and Environmental Microbiology, v. 67, p. 3291-3294, 2001. 
LI, W.; GRAUR, D. Molecular phylogeny: fundamentals of molecular evolution. Sunderland: Sinauer Associates, 1991. p. 99-135.

LIN, M.; Al-HOLY, M.; CHANG, S.; HUANG, Y.; CAVINATO, A.G.; KANG, D.; RASCO, B.A. Rapid discrimination of Alicyclobacillus strains in apple juice by Fourier transform infrared spectroscopy. International Journal of Food Microbiology, v. 105, n. 3, p. 369-376, 2005.

MALINOW, M.R.; CONNOR, W.E.; MCLAUGHLIN, P. Cholesterol and bile acid balance in Macaca fascicularis effects of alfalfa saponins. Journal of Clinical Investigation, v. 67, p. 156-162, 1981.

MALORNY, B.; TASSIOS, P.T.; RADSTROM, P.; COOK, N.; WAGNER, M.; HOORFAR, J. Standardization of diagnostic PCR for the detection of foodborne pathogens. International Journal of Food Microbiology, v. 83, p. 39-48, 2003.

MATIOLI, M.C.F. Noções de Filogenética Molecular. Biológico, v. 63, n. 1, p. 37-38, 2001.

MATSUBARA, H.; GOTO, K.; MATSUMURA, T.; MOCHIDA, K.; IWAKI, M.; NIWA, M.; YAMASATO, K. Alicyclobacillus acidiphilus sp. nov., a novel thermo-acidophilic, $\omega$-alicyclic fatty acidcontaining bacterium isolated from acidic beverages.

International Journal of Systematic and Evolutionary Microbiology, v. 52, p. 1681-1685, 2002.

McKILLIP, J.L.; JAYKUS, L.A.; DRAKE, M. rRNA Stability in heat-killed and UVirradiated enterotoxigenic Staphylococcus aureus and Escherichia coli O157:H7. Applied and Environmental Microbiology, v. 64, n. 11, p. 4264-4268, 1998.

McKILLIP, J.L.; JAYKUS, L.A.; DRAKE, M. A comparison of methods for the detection of Escherichia coli $\mathrm{O} 157: \mathrm{H} 7$ from artificially-contaminated dairy products using PCR. Journal Applied Microbiology, v. 89, n. 1, p. 49-55, 2000.

MCINTYRE, S.; IKAWA, J.Y.; PARKINSON, N.; HAGLUND, J.; LEE, J. Characterization of an acidophilic Bacillus strain isolated from shelf-stable juices. Journal and Food Protection, v. 58, p. 319-323, 1995.

MOTOHIRO, N.; HIROKO, S. Selective culture médium for detecting thermotolerant acid-fast bacillus and its detection. JP 06-283459, 17 Nov. 1994.

MURAKAMI, M.; TEDZUKA, H.; YAMAZAKI, K. Thermal resistance of Alicyclobacillus acidoterrestris spores in different buffers and $\mathrm{pH}$. Food Microbiology, v. 15, p. 577, 1998.

MURGU, M. e RODRIGUES-FILHO, E. Dereplication of glycosides from Sapindus saponaria using Liquid Chromatography-Mass Spectrometry. Journal Brazilian Chemistry Society, v. 17, n. 7, p. 1281-1290, 2006.

NACHAMKIN, I., PANARO, N., HUONG UNG, M.L., KRICKA, L.; WILDING, P.; Agilent 2100 Bioanalyzer for Restriction Fragment Length Polymorphism Analysis of 
the Campylobacter jejuni Flagellin Gene. Journal of Clinical Microbiology, v. 39, n. 2, p. 754-757, 2001.

NEI, M.; KUMAR, S. Molecular evolution and phylogenetics. Oxford: Oxford University, 2000. p. 79.

NORTON, D.M. Polymerase chain reaction-based methods for detection of Listeria monocytogenes: toward real-time screening for food and environmental samples. Journal AOAC International, v. 85, n. 2, p. 505-515, 2002.

OAKENFUL, D. Saponins in Food - a Review. Food Chemistry, v. 6, p. 19-24, 1981.

O`CONNELL, J. RT-PCR Protocols: nested RT-PCR. Totowa: Humana Press, 2002. v. 193.

OLESZEK, W.A. Saponis. In: NAIDU, A. S. (Ed.). Natural food antimicrobial systems. Boca Raton: CRC, 2000. p. 295-324.

OLESZEK, W.A; Chromatographic determination of plant saponins. Journal of Chromatography A, v. 967, p. 147-162, 2002.

OLSEN, G.J.; WOESE, C.R. Ribosomal RNA: a key to phylogeny. The FASEB Journal, v. 7, p. 113-123, 1993.

ORR, R.V.; SHEWEFELT, R.; HUANG, C.; TEFERA, S.; BEUCHAT, R.L.; Detection of guaiacol produced by Alicyclobacillus acidoterrestris in apple juice by sensory in chromatographyc analysis and comparison with spore and vegetative cell population. Journal of Food Protection, v. 63, p. 1517-1522, 2000.

OSHIMA, M.; ARIGA, T. $\omega$-cyclohexil fatty acids in acidophilic thermophilic bacteria. Journal of Biological Chemistry, v. 17, p. 6963-6968, 1975.

OTTA, S. Control of Thermoacidophilic Alicyclobacillus acidoterrestris by barley and wheat $\alpha$ and $\beta$ Thionins. Bulletin of the Natural Agriculture Research Center, v. 1, p. 49-59, 2002.

PANARO N.J.; YUEN P.K.; SAKAZUME T.; FORTINA P.; KRICKA L.J.; WILDING P. Evaluation of DNA fragment sizing and quantification by the Agilent 2100 bioanalyzer. Clinical Chemistry, v. 4, p. 1851-1853, 2000.

PASSOS-BUENO M.R.S.; MOREIRA, E.S. Ferramentas básicas da genética molecular humana. Genômica. São Paulo: Atheneu, 2004. p. 43-67.

PATEL, J.B.; LEONARD, D.G.; PAN, X.; MUSSER, J.M.; BERMAN, R.E.; NACHAMKIN, I. Sequence-based identification of Mycobacterium species using the MicroSeq 500 16S rDNA bacterial identification system. Journal Clinical Microbiology, v. 38, p. 246-251, 2000.

PELCZAR JUNIOR, M.J.; CHAN, E.C.; KRIEG, N.R. Microbiologia: conceitos e aplicações. São Paulo: Makron Books, 1997. v. 1, p. 43-44. 
PETTIPHER, G.L.; OSMUNDSON, M.E. Methods for the detection, enumeration and identification of Alicyclobacillus acidoterrestris. Food Austrália, v. 57, p. 293, 2000.

PINHATTI, M. E. Isolamento e caracterização de Alicyclobacillus e estudo de sua ocorrência em sucos de frutas industrializados. 1999. 95 f. Dissertação: (Mestrado em Ciências dos Alimentos) - Departamento de Ciências de Alimentos, Universidade Estadual de Campinas, Campinas, 1999.

POSEDI, J.; DROGEMULLER, M.; SCHNIEDER, T.; HOGLUND, J.; LICHTENFELS. J.R.; SAMSON-HIMMELSTJERNA, G. Microchip capillary electrophoresis-based genetic comparison of closely related cyathostomin nematode parasites of horses using randomly amplified polymorphic DNA polymerase chain reaction. Parasitology Research, v. 92, p. 421-429, 2003.

PRIEST, F.G. Isolation and Identification of aerobic endospore-forming Bacteria. In: HARWOOD, C.R. (Ed.). Bacillus biotechnology handbooks. London: Plenum Press, 1989. v. 2, p. 27-56.

ROSENFIELD, D. Development of reverse transcription polymerase chain reaction (RT-PCR) approaches to the detection of bacterial and viral food-borne disease agents. 1998. 116 f. Tese (Doutorado em Ciências de Alimentos) - Food Sciences Institute, North Carolina State University, Raleigh, 1998.

ROSENTHAL, L.J.; IANDOLO, J.J. Thermally induced intracellular alteration of ribosomal ribonucleic acid. Journal Bacteriology, v. 103, p. 833-835, 1970.

SAITOU, N.; NEI, M. The neighbor-joining method: a new method for reconstructing phylogenetic trees. Molecular Biology and Evolution, v 4, p. 406-425, 1987.

SCHEU, P.M.; BERGHOF, K.; STAHL, U. Detection of pathogenic and spoilage micro-organisms in food with the polymerase chain reaction. Food Microbiology, v. 15, p. 13-31, 1998.

SHEARER, A.E.H.; DUNNE, C.P.; SYKES, A.; HOOVER, D.G. Bacterial spore inihibition and inactivation in foods by pressure, chemical preservatives and mild heat. Journal of Food Protection, v. 63, p. 1503-1510, 2000.

SILVA, F.M.; GIBBS, P.; VIEIRA, M.C.; SILVA, C.L.M. Thermal inactivation of Alicyclobacillus acidoterrestris spores under diffeent temperature, soluble solids and $\mathrm{pH}$ conditions for the design of fruit processes. International Journal of Food Microbiology, v. 51, p. 95, 1999.

SILVA, F.V.M.; Gibbs, P. Alicyclobacillus acidoterrestris spores in fruit products and design of pasteurization processes, review. Trends Food Sciences Technology, v. 12, p. 68, 2001.

SIMÕES, C.M.O.; SCHENKEL, E.P.; GOSMANN, G.; MELLO, J.C.P; MENTZ, L.A.; PETROVICK, P. Farmacognosia: da planta ao medicamento. Porto

Alegre/Florianópolis : UFRGS/UFSC, 1999. v. 1, p. 821. 
SPLITTSTOESSER, D.F.; CHUREY, J.J.; LEE, C.Y. Growth characteristics of aciduric sporeforming bacilli isolated from fruit juices. Journal of Food Protection, v. 57, p. 1080, 1994.

SWOFFORD, D.L.; OLSEN, G.J.; WADDELL, P.J.; HILLIS, D.M. Phylogenetic inference. In: HILLIS, D.M.; MORITZ, C.; MABLE, B.K. (Eds.). Molecular systematics. Sunderland: Sinauer, 1996. p. 407-514.

VIEIRA, M.C.; TEIXEIRA, A.A.; SILVA, F.M.; GASPAR, N.; SILVA, C.L.M. Alicyclobacillus acidoterrestris spores as a target for Cupuaçu (Theobroma grandiflorum) nectar thermal processing: kinetic parameters and experimental methods. International Journal of Food Microbiology, v. 77, p. 71, 2002.

WALLS, I.; CHUYATE, R. Alicyclobacillus-Historical perspective and preliminary characterization study. Dairy Food and Environmental Sanitation, v. 18, p. 499, 1998.

WEBSTER, J.A.; WALLS, I.; MCDOWELL, C.I.; NEWBAUER, J.; HUBNER, R.J. Use of normalized ribotyping to describe acidophilic, sporeformes isolates from fruits and fruit juices. Abstracts of the General Meeting of the American Society for Microbiology, v. 96, p. 378, 1996.

WELSH, J.; MCLELLAND, M. Fingerprinting genomes using PCR with arbitrary primers. Nucleic Acids Research, v. 18, n. 24, p. 7213-7218, 1990.

WISOTZKEY, J.D.; JURTSHUK, P.; FOX, G.E.; DEINHARD, D.; PORALLA, K. Comparative Sequence Analyses on The 16sS rRNA(rDNA) Of Bacillus acidocaldarius, Bacillus acidoterrestris and Bacillus cycloheptanicus and proposal for creation of a new genus Alicyclobacillus Gen. Nov. International Journal of Systematic Bacteriology, v. 42, p. 263-269, 1992.

WISSE, C.A.; PARISH, M.E. Isolation and enumeration of sporeforming, thermoacidophilic, rod shaped bacteria from citrus processing environments. Dairy Food and Environmental Sanitation, v. 18, n. 8, p. 504-509, 1998.

WOESE, C.R.; KANDLER, O.; WHEELIS, M.L. Towards a natural system of organisms: proposal for the domains Archarea, Bacteria and Eucarya. Proceedings of the National Academy of Sciences of the USA, v. 87, p. 4576-4579, 1990.

YAMAZAKI, K.; MURAKAMI, M.; KAWAI, Y.; INOUE, N.; MATSUDA, T. Use of nisin for inihibition of Alicyclobacillus acidoterrestris in acidic drinks. Food Microbiology, v. 17, p. $315-320,2000$.

YAMAZAKI, K.; TEDUKA, H.; INOUE, N.; SHINANO, H. Specific primers for detection of Alicyclobacillus acidoterrestris by RT-PCR. Letters in Applied Microbiology, v. 23, p. 350, 1996. 